\section{Pacific Northwest}

National Laboratory

Operated by Battelle for the

U.S. Department of Energy

\title{
Dry Storage Demonstration for High-Burnup Spent Nuclear Fuel-Feasibility Study
}

\author{
M. A. McKinnon \\ M. E. Cunningham
}

August 2003

Prepared for the U.S. Department of Energy under Contract DE-AC06-76RL01830 


\title{
DISCLAIMER
}

This report was prepared as an account of work sponsored by an agency of the United States Government. Neither the United States Government nor any agency thereof, nor Battelle Memorial Institute, nor any of their employees, makes any warranty, express or implied, or assumes any legal liability or responsibility for the accuracy, completeness, or usefulness of any information, apparatus, product, or process disclosed, or represents that its use would not infringe privately owned rights. Reference herein to any specific commercial product, process, or service by trade name, trademark, manufacturer, or otherwise does not necessarily constitute or imply its endorsement, recommendation, or favoring by the United States Government or any agency thereof, or Battelle Memorial Institute. The views and opinions of authors expressed herein do not necessarily state or reflect those of the United States Government or any agency thereof.

\author{
PACIFIC NORTHWEST NATIONAL LABORATORY \\ operated by \\ BATTELLE \\ for the \\ UNITED STATES DEPARTMENT OF ENERGY \\ under Contract DE-AC06-76RL01830
}

Ty 


\section{CITATIONS}

This report was prepared by

Pacific Northwest National Laboratory

902 Battelle Boulevard

Richland, WA 99352

Principal Investigators

M. A. McKinnon

M. E. Cunningham

This report describes research sponsored by EPRI and U.S. Department of Energy under the Nuclear Energy Plant Optimization (NEPO) Program.

This report is a corporate document that should be cited in the literature in the following manner:

Dry Storage Demonstration for High-Burnup Spent Nuclear Fuel - Feasibility Study, EPRI, Palo Alto, CA, and U.S. Department of Energy, Washington, DC: 2003. 1007872 


\section{ABSTRACT}

Initially, casks for dry storage of spent fuel were licensed for assembly-average burnup of about $35 \mathrm{GWd} / \mathrm{MTU}$. Over the last two decades, the discharge burnup of fuel has increased steadily and now exceeds $45 \mathrm{GWd} / \mathrm{MTU}$. With spent fuel burnups approaching the licensing limits (peak rod burnup of $62 \mathrm{GWd} / \mathrm{MTU}$ for pressurized water reactor fuel) and some lead test assemblies being burned beyond this limit, the need was identified for a confirmatory dry storage demonstration program after the U.S. Nuclear Regulatory Commission (NRC) published their Interim Staff Guidance 11 (ISG-11) in May 1999. With the publication of the second revision of ISG-11 in July 2002, the desirability for such a program further increased to obtain confirmatory data about the potential changes in cladding mechanical properties induced by dry storage, which would have implications to the transportation, handling, and disposal of high-burnup spent fuel. While dry storage licenses have kept pace with reactor discharge burnups, transportation licenses have not - and are considered on a case by case basis. Therefore, this feasibility study was performed to examine the options available for conducting a confirmatory experimental program supporting the dry storage, transportation, and disposal of spent nuclear fuel with burnups well in excess of $45 \mathrm{GWd} / \mathrm{MTU}$.

Six utilities with existing independent spent fuel storage installations (ISFSIs), four dry storage system vendors, two fuel vendors, and six national laboratories were contacted as part of this study. Each expressed interest in supporting a demonstration program. After reviewing the survey information, three options were retained for a confirmatory experimental program:

- Augment existing utility fuel examination programs. Several utilities conduct fuel examination programs to augment the current high-burnup fuel information. They have, or will soon have, high-burnup fuel that can be examined. These programs could be augmented with emphasis on cladding post-irradiation mechanical testing and characterization.

- Perform the demonstration at an existing ISFSI and post-irradiation examination (PIE) at a national laboratory. A fuel vendor would perform pool examination of the spent fuel before putting it into a storage system at a utility site. A license amendment would be obtained from the NRC for minor storage system modifications needed to support temperature measurements and gas sampling. At the end of a specified period, the fuel would be examined and the effect of dry storage on the mechanical properties of the cladding determined.

- Perform the demonstration and PIE at a national laboratory. A fuel vendor at the utility's spent fuel pool would perform a poolside nondestructive examination before shipping the fuel to a national laboratory, where it would be placed into a dry storage system. A modified dry storage system or transportation cask would be used for the demonstration. After the specified storage period the spent fuel would be examined and the effects of dry storage on the mechanical properties of the cladding determined. 


\section{EXECUTIVE SUMMARY}

The abandonment of the reprocessing option and the delays in opening a permanent repository for disposing of spent nuclear fuel have forced many utilities to rely on independent spent fuel storage installations (ISFSIs) for storage of their spent fuel on an interim basis. After reracking existing spent fuel pools to increase storage density, the preferred approach is to store spent fuel in modular systems that maintain a dry, inert atmosphere. Initially, the dry storage systems approved by the U.S. Nuclear Regulatory Commission (NRC) were licensed for fuel burnups on the order of $35 \mathrm{GWd} / \mathrm{MTU}$. Today, discharge burnup levels routinely exceed $45 \mathrm{GWd} / \mathrm{MTU}$. Dual-purpose cask systems have been licensed for the dry storage of the higher burnup spent fuel with the intent to license them for transportation. The transportation licenses have not been obtained and are being considered on a case by case basis.

Increasing burnup generally results in increased levels of oxidation and hydriding of the cladding; higher fuel rod internal pressures due to higher fission gas release from the fuel pellets; and, consequently, higher hoop stresses in the cladding. These phenomena need to be evaluated for their effects on fuel integrity during storage as well as during subsequent operations including transportation, retrieval and placement in a waste package, and, eventually, disposal. Mechanical properties of specific interest include creep, ductility under impact load conditions, and fracture toughness. These properties determine the ability of the cladding to maintain the fuel in the configuration that is, or will be, used for licensing analyses, specifically in the criticality, shielding, and retrievability evaluations. Therefore, as discharge burnup levels continue to increase, additional experimental data are needed to confirm and support the licensing of dry storage systems and to determine the effects of dry storage on the cladding mechanical properties important to transportation, handling, and disposal operations involved in closing the fuel cycle.

Under the Nuclear Energy Plant Optimization (NEPO) program, in collaboration with the utility industry represented by the Electric Power Research Institute (EPRI), and with the participation of the NRC, the U.S. Department of Energy (DOE) funded this study to examine the options available for a confirmatory experimental program supporting regulatory acceptance of practical approaches for storing and later transporting spent fuel with burnup in excess of $45 \mathrm{GWd} / \mathrm{MTU}$ under a dry, inert atmosphere. Selected utilities, fuel vendors, dry storage system vendors, and national laboratories were surveyed for information on available high-burnup spent fuel, interest in participating in a confirmatory demonstration program, and technical capabilities available to support such a program.

The envisioned program would consist mainly of pre- and post-storage examinations of the spent fuel cladding. It is proposed that spent fuel temperatures and cask fill-gas composition be monitored during the storage period ( $>$ five years) as well. Pre-storage fuel examinations would be performed in the spent fuel pool at a utility site. In addition, to provide baseline data, one or 
several (preferably four or more) sibling rods would be left in the pool for destructive examination at a later time. Post-storage examinations would focus on fuel rod dimensional changes, cladding oxidation and hydriding characteristics, fission gas release measurements, and cladding mechanical properties.

Several utilities with ISFSIs were contacted to determine their interest in participating in the potential demonstration program. There was general interest in the program, and available spent fuel was identified to support the program. The following common issues were raised:

- A demonstration program cannot interfere with normal utility operations or slow down existing programs.

- If spent fuel were to leave the site, ownership would be transferred, and the fuel could not be returned to the utility site.

- License amendments are needed for modifying a cask in support of the demonstration.

- Funding would be needed to defray the cost to the utility for its participation.

Four cask vendors were contacted to determine their interest in participating in the potential demonstration program. They all expressed general interest and identified their cask systems that would be available. It would likely require two years to prepare, submit, and receive approval for the necessary license amendment to modify a cask for monitoring fuel temperatures and cask fill-gas composition.

Five national laboratories responded to a survey questionnaire soliciting interest in the program and information about examination capabilities. The following are some points of interest and common issues:

- Only Idaho National Engineering and Environmental Laboratory (INEEL) (using Test Area North) (TAN) and Argonne National Laboratory-West (ANL-W) (using the Hot Fuels Examination Facility) are able to handle the casks of interest and perform examinations on full-length rods at this time.

- All national laboratories would require a plan to deal with the spent fuel before it could be accepted for examination. This would require the participation and approval of DOE and, in some cases, state governments or other agencies.

- All national laboratories recommended minimizing the quantity of spent fuel brought to the laboratory. Alternative approaches to the confirmatory demonstration program were proposed that would focus on fuel behavior and minimize the quantity of fuel that would be needed.

- Either wet or dry transfer of spent fuel between shipping casks, storage casks, and examination facilities is acceptable. Requiring dry transfer only would be a significant issue that would require new facilities or substantial facility modifications.

- Cost estimates to serve as the demonstration site and/or the fuel examination site varied widely because the scope of the potential confirmatory program was not well defined. 
After reviewing the survey information, three options are recommended for conducting a confirmatory experimental program. A primary assumption is that fuel clad in Zircaloys as well as in advanced claddings (Zirlo ${ }^{\mathrm{TM}}$ and M5), with burnups at or close to the current licensing peak rod limit of $62 \mathrm{GWd} / \mathrm{MTU}$ and irradiated in high-duty fuel cycles for fission gas releases as high as possible, would be selected for the program. In addition, it would be desirable to generate peak cladding temperatures above the accepted licensing limit of $400^{\circ} \mathrm{C}$. The following are the three identified options:

- Augmentation of an existing utility program. Several utilities, in cooperation with fuel vendors, conduct programs to characterize fuel performance during reactor operation. These programs use lead test assemblies (LTAs) to achieve higher burnups. The opportunity exists for additional nondestructive poolside analysis of the LTAs at the reactor site and additional destructive analysis in a hot cell facility (after sufficient cooling of the fuel to allow shipment). These programs would provide information on the effect of high burnup on the mechanical properties of the fuel cladding at the time the fuel is discharged from the reactor and before it is placed into dry storage. They would not provide confirmatory data on the performance of spent fuel during dry storage and the effects of dry storage on cladding properties.

- Demonstration at an existing ISFSI. This option would rely on a modified storage system for use at an existing ISFSI. The modifications (otherwise the system is the same as that now used at the site) would allow for monitoring fuel temperatures and periodically sampling the storage system's backfill gas composition. A fuel vendor would perform poolside examination of the spent fuel selected for the demonstration. One or several sibling rod(s) would be identified in assemblies with power histories similar to the ones being placed in dry storage or possibly extracted from the fuel assemblies to be placed in dry storage. The sibling rod(s) would be stored in the pool until the end of the dry storage demonstration, when they would be sent with selected dry-stored rods to a national laboratory for examination.

This option has the advantage of minimizing the quantity of spent fuel that would be shipped off site for examination. It also allows using a slightly modified commercial storage system with approved procedures and ancillary equipment. The modifications would be limited to those required to permit gas sampling and temperature measurements. The modified storage system components would be disposed of as low-level waste at the end of the demonstration, and the remaining fuel would be placed and stored in a standard licensed dry storage system. This option is limited to a single fuel type (PWR or BWR) with a range of burnup and cladding materials available at the reactor site.

- Demonstration at a national laboratory. This option would transfer selected spent fuel to a national laboratory, place the fuel in a modified spent fuel cask, and then perform interim and final examinations of the spent fuel. The INEEL/ANL-W sites (if used in conjunction with ANL-E) and ORNL have the capability to conduct such a program by the time the project would start. The other laboratories could upgrade their capabilities given sufficient time and project funding.

This option, while potentially providing the most flexibility in performing the confirmatory program, is likely to be the most expensive and complex, but would provide the most complete data. The INEEL/ANL-W site, while technically capable to conduct the project, 
Summary

has a policy, because of an agreement with the State of Idaho, that prohibits spent fuel being brought into and residing in the state for $>5$ years, which is not commensurate with the needs of the demonstration program.

Estimated costs and schedule for the three options are provided in Table S-1. The options are estimated to run from 5 to 12 years with destructive post-irradiation examinations (PIEs) conducted at project start, at 5 years, and at 10 years. Costs range from $\$ 5 \mathrm{M}$ to over $\$ 21 \mathrm{M}$ depending on the location and scope of the project.

Table S-1

Estimated Duration and Costs for Confirmatory Program Options (costs in \$M)

\begin{tabular}{|c|c|c|c|}
\hline Activity & $\begin{array}{l}\text { Option A } \\
\text { Augment Existing } \\
\text { Examination } \\
\text { Program }\end{array}$ & $\begin{array}{c}\text { Option B } \\
\text { Utility ISFSI Followed } \\
\text { by Laboratory } \\
\text { Examination }\end{array}$ & $\begin{array}{l}\text { Option C } \\
\text { Laboratory } \\
\text { Storage and } \\
\text { Examination }\end{array}$ \\
\hline Estimated duration of program, yr & 5 & 12 & 12 \\
\hline Program management ${ }^{(a)}$ & 1.0 & 4.0 & 4.0 \\
\hline Demonstration storage system ${ }^{(b)}$ & 0.0 & 4.5 to $5.5^{(\mathrm{c})}$ & $6.6^{(\mathrm{d})}$ \\
\hline Pool-side NDE & $>0.0^{(\mathrm{e})}$ & $>0.2^{(f)}$ & $>0.2^{(\mathrm{g})}$ \\
\hline Shipping to laboratory & 0.3 & 0.3 & 0.3 to $>1.0^{(\mathrm{h})}$ \\
\hline $\begin{array}{l}\text { Dry storage demonstration period with } \\
\text { periodic monitoring and surveillance } e^{(i)}\end{array}$ & 0.0 & 1.5 & 1.5 \\
\hline Post-storage fuel rod examination & $3.0^{(j)}$ & 4.0 to $7.0^{(\mathrm{k})}$ & 4.0 to $7.0^{(\mathrm{k})}$ \\
\hline Post-test disposal and cleanup & 1.0 & 1.0 & $>1.0^{(l)}$ \\
\hline TOTAL & $\$ 5.3 \mathrm{M}$ & $\$ 15.5 \mathrm{M}$ to $>\$ 19.5 \mathrm{M}$ & $\begin{array}{l}\$ 17.6 \mathrm{M} \text { to } \\
>\$ 21.3 \mathrm{M}\end{array}$ \\
\hline \multicolumn{4}{|c|}{$\begin{array}{l}\text { (a) Includes management and planning, quality assurance, reviews, reporting, records, contracting, etc. } \\
\text { (b) Includes procuring storage system, physical modifications, licensing, labor for loading, etc. } \\
\text { (c) Includes cost estimate to return fuel to standard storage system after removing fuel selected for PIE. } \\
\text { (d) Includes additional licensing and issues such as NEPA, safety analysis reports, etc., necessary for } \\
\text { performing the demonstration at a laboratory site. } \\
\text { (e) May not be necessary to augment the examinations already planned by the utility. } \\
\text { (f) Would likely be performed both before and after the dry storage demonstration period. } \\
\text { (g) May select fuel from more than one source, requiring more than one set of poolside examinations. } \\
\text { (h) May select fuel from more than one source, requiring more than one shipping operation. } \\
\text { (i) Assumes regular surveillance and maintenance with temperature monitoring and backfill gas } \\
\text { analyses but no interim fuel rod examinations; includes post-storage examination of storage system. } \\
\text { (j) Augment planned examinations and obtain cladding mechanical property data. } \\
\text { (k) Nondestructive, destructive, and cladding mechanical property data; upper range of cost estimate is } \\
\text { for modifications to receive and examine full-length fuel rods, depending on where the examinations } \\
\text { are performed. }\end{array}$} \\
\hline
\end{tabular}




\section{ACKNOWLEDGMENTS}

The authors would like to recognize those who have directed the work, provided funding, and reviewed the results. The work was conducted under the joint DOE-EPRI strategic research and development plan to optimize U.S. nuclear power plants as part of Project 5-103, "Dry Storage of Spent Fuel with Burnup in Excess of 45 GWd/MTU."

We also recognize the contributions to the report of fuel and cask vendors, national laboratories, and utilities listed below.

\section{Cask Vendors}

GNSI/GNB

Holtec International

NAC International

Transnuclear

\section{National Laboratories}

Argonne National Laboratory-West

Idaho National Engineering and Environmental Laboratory

Oak Ridge National Laboratory

Pacific Northwest National Laboratory

Savannah River Technical Center

\section{Nuclear Utilities}

Constellation Energy Group

Dominion

Duke Power

Xcel

Entergy

Exelon 


\section{ACRONYMS AND ABBREVIATIONS}

\begin{tabular}{|c|c|}
\hline ANL-E & Argonne National Laboratory-East \\
\hline ANL-W & Argonne National Laboratory-West \\
\hline ATM & Approved Testing Material \\
\hline BWR & Boiling-Water Reactor \\
\hline CFR & Code of Federal Regulations \\
\hline DOE & U.S. Department of Energy \\
\hline DOE-EM & DOE Environmental Management \\
\hline DOE-NE & DOE Nuclear Energy \\
\hline DOE-RL & DOE Richland \\
\hline EPRI & Electric Power Research Institute \\
\hline GNSI & General Nuclear Systems, Inc. \\
\hline GWd/MTU & Designates burnup in gigawatt days per metric ton uranium \\
\hline HFEF & Hot Fuels Examination Facility at ANL-W \\
\hline HFIR & High Flux Isotope Reactor at ORNL \\
\hline IFEL & Irradiated Fuels Examination Laboratory at ORNL \\
\hline INEEL & Idaho National Engineering and Environmental Laboratory \\
\hline ISFSI & Independent Spent Fuel Storage Installation \\
\hline ISG & Interim Staff Guidance provided by the Nuclear Regulatory Commission \\
\hline LTA & Lead Test Assembly \\
\hline
\end{tabular}


LVDT Linear Variable Differential Transformer

LWR Light-Water Reactor

LWT Legal Weight Truck

NAC Nuclear Assurance Corporation International

NEPO Nuclear Energy Plant Optimization

NLI NL Industries Inc.

NRC U.S. Nuclear Regulatory Commission

OCRWM Office of Civilian Radioactive Waste Management

ORNL Oak Ridge National Laboratory

PIE Post-Irradiation Examination

PNNL Pacific Northwest National Laboratory

PWR Pressurized-Water Reactor

RCCA Rod Control Cluster Assembly

RFP Robust Fuel Program

RPL Radiochemical Processing Laboratory at PNNL

SRS Savannah River Site

SRTC Savannah River Technical Center

TAN Test Area North at INEEL 


\section{CONTENTS}

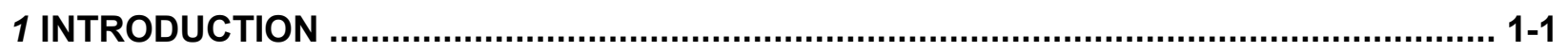

2 BACKGROUND

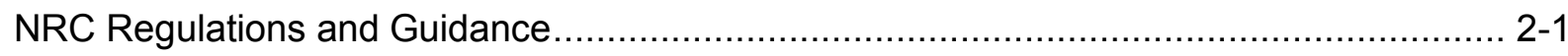

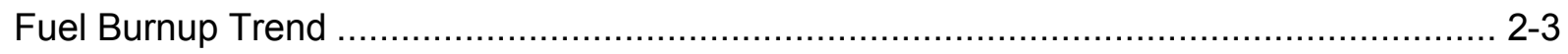

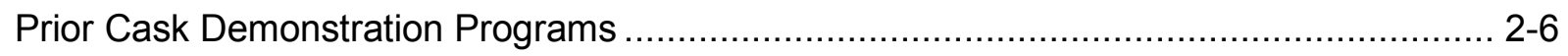

Irradiation Effects and Burnup/Exposure Dependency............................................... 2-8

Review of Current Fuel Discharge Conditions/Trends ..........................................2-11

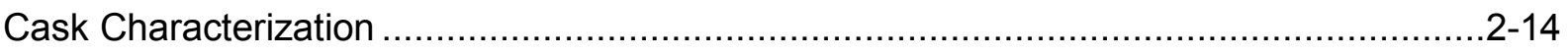

3 RESOURCES

Demonstration Sites and High-Burnup Fuel Sources.................................................. 3-1

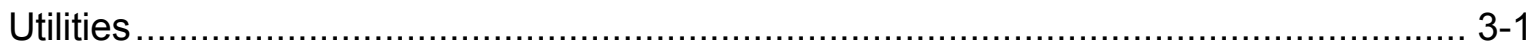

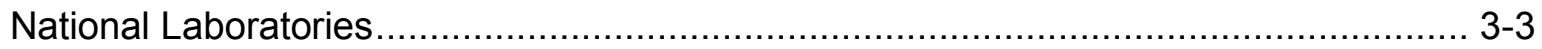

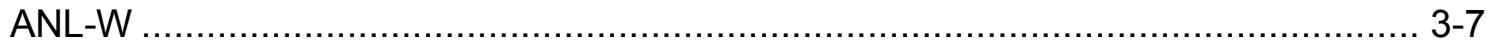

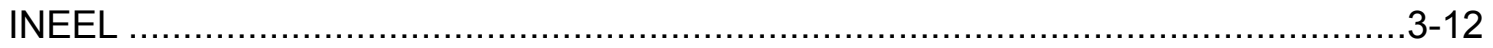

ORNL

PNNL ……

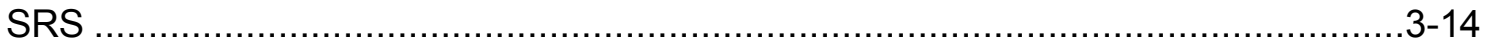

Common Laboratory Concerns …………………..................................

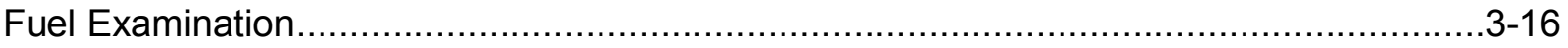

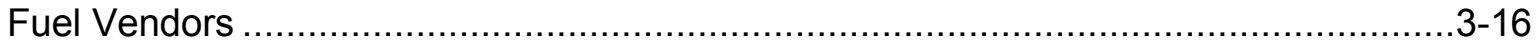

National Laboratories........................................................................................

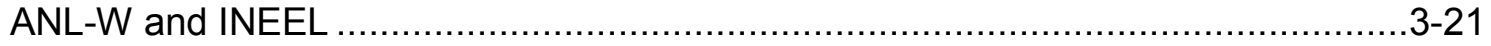

ORNL

PNNL

SRS

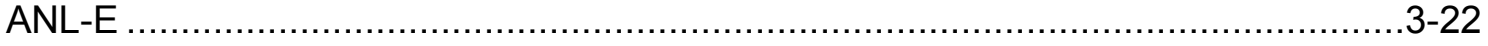


Common Laboratory Concerns ………..........................................................

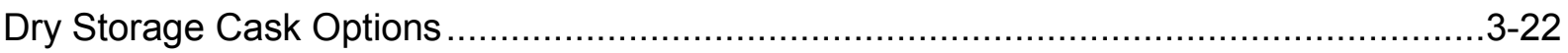

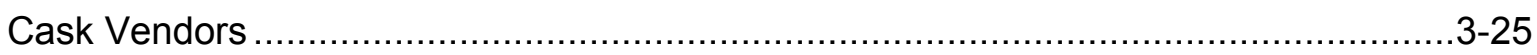

Pre- and Post-Test Examination of Storage System ……..................................... $3-28$

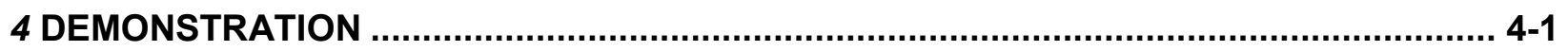

Augmentation of an Existing Utility Program ............................................................... 4-2

Demonstration at an Existing Utility ISFSI Site ....................................................... 4-2

Demonstration at a National Laboratory ................................................................ 4-3

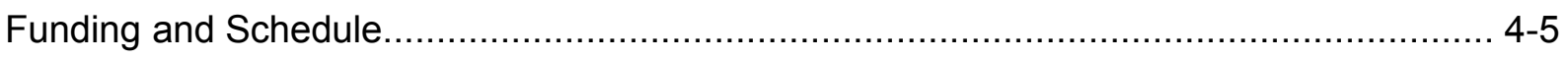

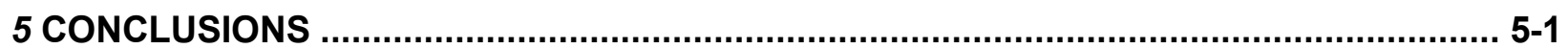

6 REFERENCES

APPENDIX A-NATIONAL LABORATORY RESPONSES TO PNNL SURVEY

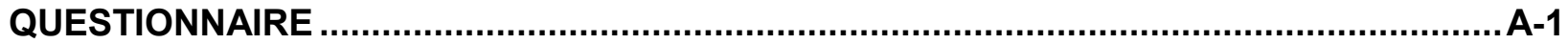




\section{LIST OF FIGURES}

Figure 2-1 Historical and Projected Discharge Burnup Trend for PWRs

Figure 2-2 Projected Number of Discharged PWR Fuel Assemblies with Burnup Levels Below and Above $45 \mathrm{GWd} / \mathrm{MTU}$

Figure 2-3 Historical and Projected Discharge Burnup Trend for BWRs

Figure 2-4 Projected Number of Discharged BWR Fuel Assemblies with Burnup Levels Below and Above $45 \mathrm{GWd} / \mathrm{MTU}$.

Figure 2-5 Illustration of Effect of Duty Cycle on Fuel Performance $2-5$

Figure 2-6 Illustration of Range of Observed Fission Gas Release Values $2-13$

Figure 2-7 Illustration of Range of Observed Cladding Oxide Thickness $2-13$

Figure 2-8 Cladding Oxide Thickness as a Function of Duty Cycle.... $2-14$

Figure 3-1 Location of Operating ISFSIs. 3-2

Figure 3-2 Potential Near-Term ISFSIs..

Figure 4-1 Schedule for Augmentation of an Existing Utility Program 4-7

Figure 4-2 Estimated Schedule for Demonstration at an Existing Utility ISFSI Site 4-8

Figure 4-3 Estimated Schedule for Demonstration at a National Laboratory 4-9 


\section{LIST OF TABLES}

Table S-1 Estimated Duration and Costs for Confirmatory Program Options...........................

Table 2-1 Fuel Used in Prior Dry Storage System Demonstrations ..................................... 2-6

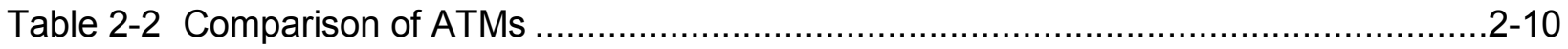

Table 3-1 Summary of Information Received from Utilities ......................................... 3-4

Table 3-2 Summary of National Laboratory Responses about Serving as

Demonstration Site

Table 3-3 Summary of National Laboratory Responses about Performing the

Fuel Examinations

Table 3-4 U.S. Generating Companies with Onsite Dry Storage Commitments ...................3-24

Table 3-5 Summary of Information Received from Cask Vendors ................................... 3-26

Table 4-1 Estimated Costs for Confirmatory Program Options ....................................... 4-6 


\section{INTRODUCTION}

The abandonment of the reprocessing option and delays in opening a permanent repository for disposing of spent nuclear fuel have forced utilities to rely on interim storage strategies involving reracking spent fuel pools and operating independent spent fuel storage installations (ISFSIs). The storage cask systems initially approved by the U.S. Nuclear Regulatory Commission (NRC) were licensed for burnups of about $35 \mathrm{GWd} / \mathrm{MTU}$. Over the last two decades the discharge burnup has steadily increased, a trend that is expected to continue for the foreseeable future. Starting in 2001 for pressurized-water reactors (PWRs) and in 2002 for boiling-water reactors (BWRs), the majority of spent fuel assemblies discharged in any given year have or will have assembly-average burnups greater than $45 \mathrm{GWd} / \mathrm{MTU}$. By 2007 , over $90 \%$ of the assemblies to be discharged are expected to have burnups greater than $45 \mathrm{GWd} / \mathrm{MTU}$.

The increased burnup generally results in increased levels of oxidation and hydriding of the cladding; higher fuel rod internal pressures due to higher fission gas release from the fuel pellets; and, consequently, higher hoop stresses in the cladding. Increased fission gas release increases the pressure differential across the cladding during dry storage. Increased oxidation decreases the effective load-bearing metal thickness of the cladding. Both phenomena contribute to higher stresses. The combination of sufficiently high hoop stresses and high temperatures can lead to deformation and rupture of the cladding, a change in the morphology of the hydrides upon cooling, and a degradation of the cladding mechanical properties. Mechanical properties of specific interest include creep, ductility under impact loading conditions (accidents), and fracture toughness. These properties determine the ability of the cladding to maintain the fuel in the configuration that is, or will be, used for licensing analyses, specifically in the criticality, shielding, and retrievability evaluations. Therefore, as discharge burnup levels continue to increase, additional experimental data are needed to confirm and support the licensing of dry storage systems and their effects on the mechanical properties of interest for resolving issues associated with the transportation, handling, and disposal operations.

In Revision 2 of Interim Staff Guidance 11 (ISG-11, Rev. 2), the NRC staff addressed the acceptance criteria for the storage of spent fuel including assemblies with average assembly burnups exceeding $45 \mathrm{GWd} / \mathrm{MTU}$. However, the NRC staff also indicated that the transportation of high-burnup commercial spent fuel would be handled on a case-by-case basis until further guidance is developed.

Analysis of the expected performance of high-burnup spent fuel in dry storage and the effects of the latter on cladding properties is based in large measure on data obtained on spent fuel with burnup less than $45 \mathrm{GWd} / \mathrm{MTU}$. Confirmatory research and development (R\&D) on specific degradation phenomena, such as creep and hydride reorientation, often rely on testing protocols conducted over timeframes practical for laboratory investigations, but not truly representative of 
actual field conditions. Therefore, experimental validation of how high-burnup spent fuel rods and assemblies perform under prototypical conditions is highly desirable to confirm the technical bases and to validate the data used to support regulatory acceptance. Confirmatory information about cladding performance after dry storage may be needed to support practical licensing approaches for transportation of high-burnup spent fuel. Failure to resolve the issues associated with transportation of high-burnup fuel in dual-purpose (storage and transportation) systems may result in licensing and transportation delays, severe economic penalties, and operational difficulties for utilities using current storage options.

Under the Nuclear Energy Plant Optimization (NEPO) program, in collaboration with the Utility Industry represented by the Electric Power Research Institute (EPRI), and with the participation of the NRC, the U.S. Department of Energy (DOE) has funded this study to examine the options available for an experimental program to support regulatory acceptance of practical approaches for storing, and later transporting, spent fuel with burnups in excess of $45 \mathrm{GWd} / \mathrm{MTU}$ under a dry, inert atmosphere. This study assumes that a confirmatory dry storage demonstration of high-burnup spent fuel is highly desirable to provide information to the utilities, DOE, and NRC to confirm the technical bases and to validate the data used to support regulatory acceptance of practical approaches for interim dry storage, transportation, and eventually disposal of highburnup spent fuel. Based on this assumption, selected utilities, fuel and cask vendors, and national laboratories have been surveyed for information on available high-burnup spent fuel, interest in participating in a confirmatory demonstration program, and technical capabilities available to support the demonstration program.

Based on past dry storage demonstration experience (McKinnon and Deloach 1993) and a recent re-examination of spent fuel and a cask used in those demonstrations (Bare and Torgerson 2001; Kimball and Billone 2003), several assumptions for a confirmatory demonstration program were defined before potential participants were solicited. The following are the principal assumptions:

- First, the fuel and the storage system need to be well characterized prior to the dry storage of the spent fuel. The pre-storage baseline characterization of the fuel needs to include destructive and nondestructive examinations.

- Second, during storage, periodic monitoring of fuel temperatures and sampling of storage system backfill gas may be needed. Fission gas release or lack of release into the cask is a reliable indicator of fuel integrity during dry storage.

- Third, after a minimum of five years of dry storage, the fuel and storage system need to be examined to assess the effects of dry storage. It is expected that post-storage examinations would be similar to pre-storage examinations. Interim examinations may also be warranted if gas sampling shows a marked increase in concentration of fission gases in the backfill gas.

- Finally, the post-storage examination of the spent fuel should include measurements of the mechanical properties of the cladding in addition to other examinations.

Provided in this report are the results of examining options for conducting an experimental program that would generate data to confirm the technical basis for storing, and later transporting, spent fuel with burnup in excess of $45 \mathrm{GWd} / \mathrm{MTU}$ under a dry, inert atmosphere. A background discussion that addresses NRC regulations, trends in discharge burnup levels, 
prior dry storage cask demonstration programs, irradiation effects, and burnup dependencies is provided in Section 2. Section 3 presents the results of the contacts made with the selected utilities, fuel and cask vendors, and national laboratories. These contacts addressed interest, capabilities, potential cost, and other issues relevant to conducting a confirmatory demonstration program. A few potential scenarios based on the availability of demonstration sites, high-burnup fuel, fuel examination capabilities, institutional considerations, and cost estimates are presented in Section 4. Conclusions are presented in Section 5 and cited references in Section 6. The appendix contains national laboratory responses to the survey questionnaire. 


\section{2 \\ BACKGROUND}

Before considering a new experimental program focused on dry storage of spent nuclear fuel, it is necessary to review the regulatory requirements and previous work that has been performed. Previous dry storage demonstration programs were conducted in the 1980s and early 1990s. Since then, substantial increases in discharge burnup levels may challenge past assumptions for dry storing spent fuel. This section contains a brief review and summary of 1) current NRC regulations and requirements relative to dry storage and transportation of spent nuclear fuel; 2) the trend in spent fuel discharge burnup levels to define the population of spent fuel that is now expected to be dry stored; 3) previous dry storage demonstration projects; 4) the effects of irradiation on fuel, their relevance to dry storage, and available data sources; ${ }^{(1)}$ and 5) cask characterization.

\subsection{NRC Regulations and Guidance}

The NRC regulations governing the transportation and storage of spent nuclear fuel are $10 \mathrm{CFR}$ Parts 71 and 72, respectively. The regulations for storage in 10 CFR Part 72 and for transportation in 10 CFR Part 71 have the following common safety objectives: 1) ensure that the doses are less than the limits prescribed in the regulations; 2) maintain subcriticality under all credible conditions of storage and transportation; and 3) ensure there is adequate confinement and containment of the spent fuel under all credible conditions of storage and transportation.

Additionally, 10 CFR Part 72 regulations require that the spent fuel be readily retrieved from the storage systems. The requirements of 10 CFR 72.122 (h)(1) seek to ensure safe fuel storage and handling and to minimize post-operational safety problems with respect to the removal of the fuel from storage. In accordance with this regulation, the spent fuel cladding must be protected during storage against degradation that leads to gross ruptures, or the fuel must be otherwise confined such that degradation of the fuel during storage will not pose operational problems with respect to its removal from storage. 10 CFR 72.122(1) and $72.236(\mathrm{~m})$ also require that the storage system be designed to allow ready retrieval of the spent fuel for further processing or disposal.

In accordance with 10 CFR Part 71, the geometric form of the spent fuel should not be substantially altered under normal conditions of transport as analyzed and specified in the SAR. For normal conditions of transport, the licensee must ensure that there will be no loss or dispersal of spent fuel, no significant increase in external surface radiation levels, and no substantial

(1) This review only looks at Zircaloy-2 and -4 and not at "advanced" cladding materials such as Zirlo ${ }^{\mathrm{TM}}$ or M5. Data associated with the performance of advanced claddings are presently very limited. 
reduction in the effectiveness of the spent fuel package, as required by 10 CFR 71.43(f). For hypothetical accident conditions (10 CFR 71.73), the licensee must ensure that any damage to the cladding does not lead to failure to meet the criticality requirements of 10 CFR 71.55 and the shielding and containment requirements of 10 CFR 71.51 .

These regulatory requirements are supplemented by three Standard Review Plans (NRC 1997, 2000a, 2000b) that provide guidance in preparing safety analysis reports to support licensing efforts. The Standard Review Plan for the Dry Storage of Spent Fuel (NRC 1997) does not address storage of spent fuel having burnups in excess of $45 \mathrm{GWd} / \mathrm{MTU}$. However, the NRC has provided interim staff guidance (ISG) to address issues that are not addressed adequately in the current standard review plans. ISG-11 provides guidance for the storage and transportation of spent fuel up to the high burnup levels licensed by the Office of Nuclear Reactors. ISG-11's original version, entitled "Storage of Spent Fuel Having Burnups in Excess of 45,000 MWd/ MTU," was published in May 1999 (NRC 1999a); the first revision, entitled "Transportation and Storage of Spent Fuel Having Burnups in Excess of 45 GWd/MTU," was published in May 2000 (NRC 2000c); the second revision, entitled "Cladding Considerations for the Transportation and Storage of Spent Fuel" (NRC 2002c), current at the time this report was written, was published in July 2002.

Other ISGs addressing topics of interest include ISG-1 (“damaged fuel”) (NRC 2002a), ISG-2 ("fuel retrievability") (NRC 1998), ISG-5 Rev. 1 ("confinement evaluation") (NRC 1999b), ISG-15 ("Materials Evaluation") (NRC 2001), and ISG-19 ("Moderator Exclusion under Hypothetical Accident Conditions and Demonstrating Subcriticality of Spent Fuel under the Requirements of 10 CFR 71.55[e])" (NRC 2003).

ISG-11 Rev. 2 provides a discussion of the technical review aspects and acceptance criteria for limiting spent fuel reconfiguration during storage and transportation. Geometric configuration of the spent fuel is expected to be preserved when the maximum cladding temperature does not exceed $400^{\circ} \mathrm{C}$ for normal storage conditions and short-term operations including cask drying and backfilling. In addition, repeated thermal cycling with temperature differences greater than $65^{\circ} \mathrm{C}$ is not permitted during fuel loading operations. For accidents involving a fire or off-normal thermal transients, a higher cladding temperature is specified.

For transportation, the staff stated that full reliance on cladding integrity ${ }^{(2)}$ during hypothetical accident conditions of transport would require further information on the impact properties (ductility and fracture toughness) of cladding material. Therefore, until further guidance is developed, the transportation of high-burnup commercial spent fuel is to be handled on a caseby-case basis.

(2) ISG-19 provides presently untested avenues other than "reliance on cladding integrity" for satisfying the criteria given in 10 CFR 71.55 . 


\subsection{Fuel Burnup Trend}

The trend in discharge burnup level for spent fuel has increased steadily since the cask demonstration and fuel examination programs of the late 1980s and early 1990s. Assembly-average burnup levels for those demonstration programs were less than $40 \mathrm{GWd} / \mathrm{MTU}$. With the exception of lead test assemblies, the current reactor operating burnup limit is $62 \mathrm{GWd} / \mathrm{MTU}$ (peak rod). Today, the majority of the spent fuel discharged has burnup levels in excess of $45 \mathrm{GWd}$ /MTU (Figures 2-1 through 2-4). Thus, in a few years, most of the spent fuel going into dry storage will be at burnup levels that exceed $45 \mathrm{GWd} / \mathrm{MTU}$.

Another consideration, in addition to the burnup level, is the duty cycle to which the fuel is exposed, i.e., operating power level, temperature, and other factors. Fuel of the same burnup level can be subjected to different duty cycles that can affect fuel condition (Knott et al. 2003). For example, as presented in Figure 2-5, fuel of the same burnup level can have different levels of cladding oxidation based on duty cycle. As burnup level and fuel duty increase, the knowledge base becomes more sparse, and correspondingly their effects on fuel cladding integrity become more uncertain.

It is also very likely that, once DOE is in a position to take ownership of the spent fuel at the plant sites, the utilities will offer the higher-burnup spent fuel to maximize their flexibility in managing spent fuel pool capacity.

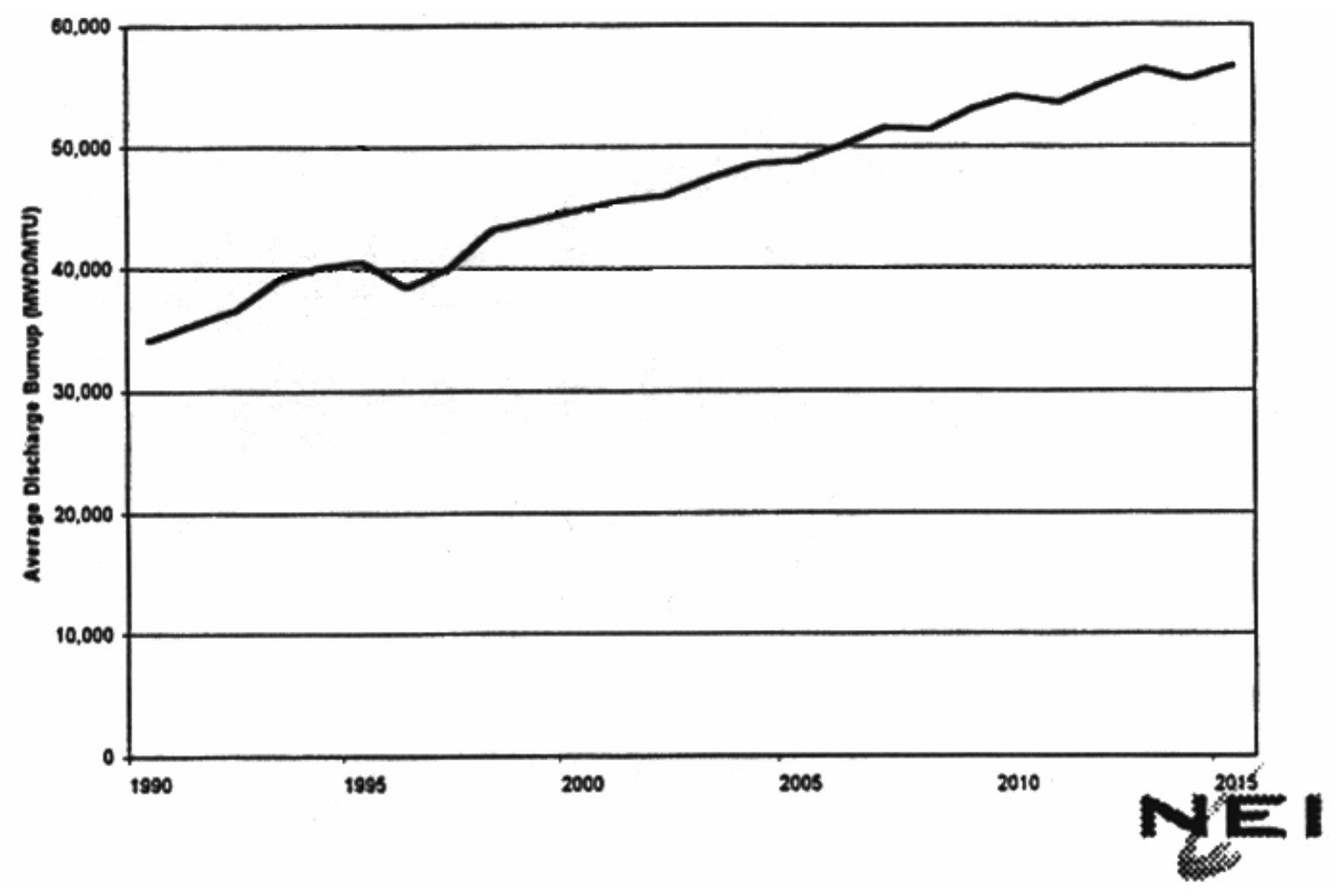

Figure 2-1

Historical and Projected Discharge Burnup Trend for PWRs (Beedle 1999) 


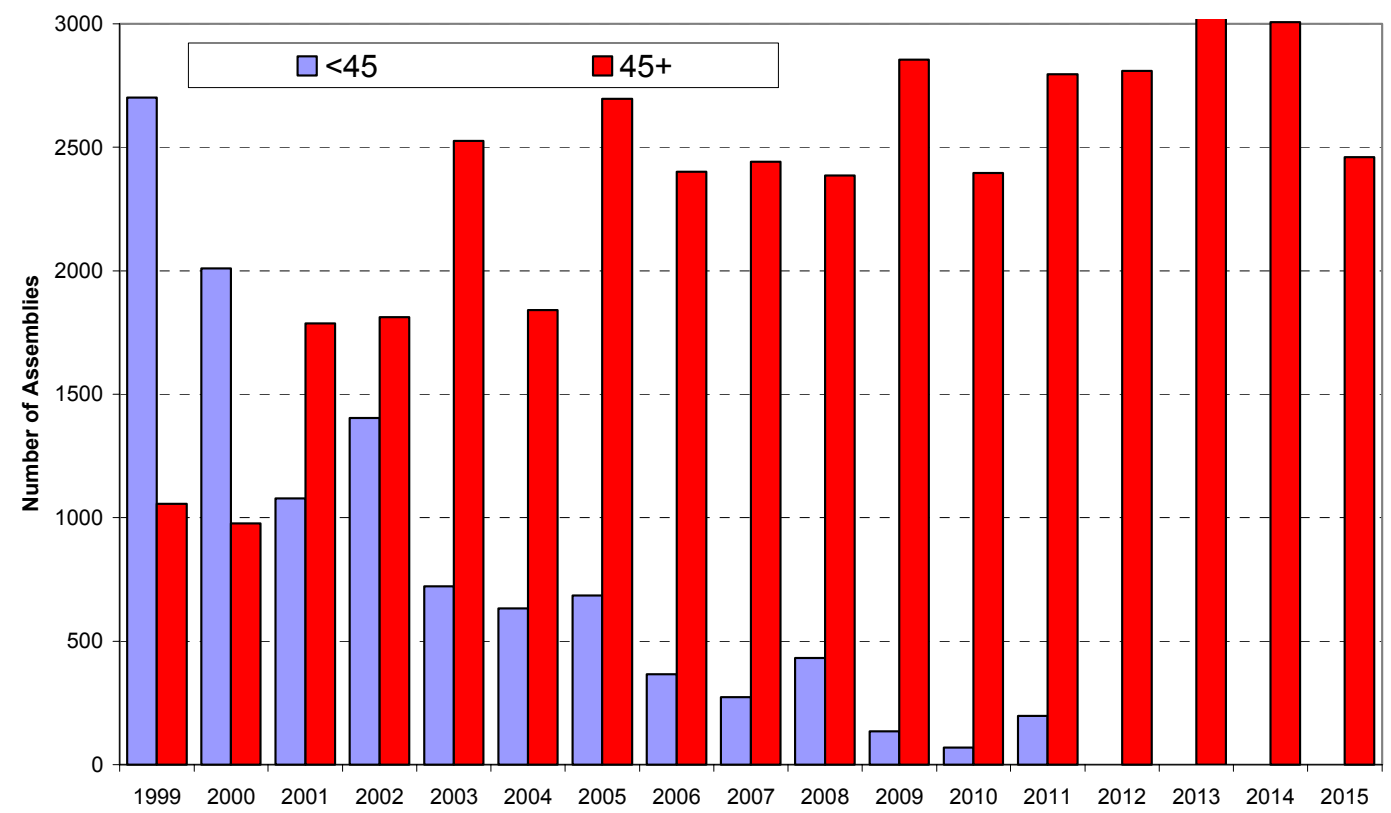

Figure 2-2

Projected Number of Discharged PWR Fuel Assemblies with Burnup Levels Below and Above 45 GWd/MTU (Gruss 2002) [originally generated by E. Supko for NEI]

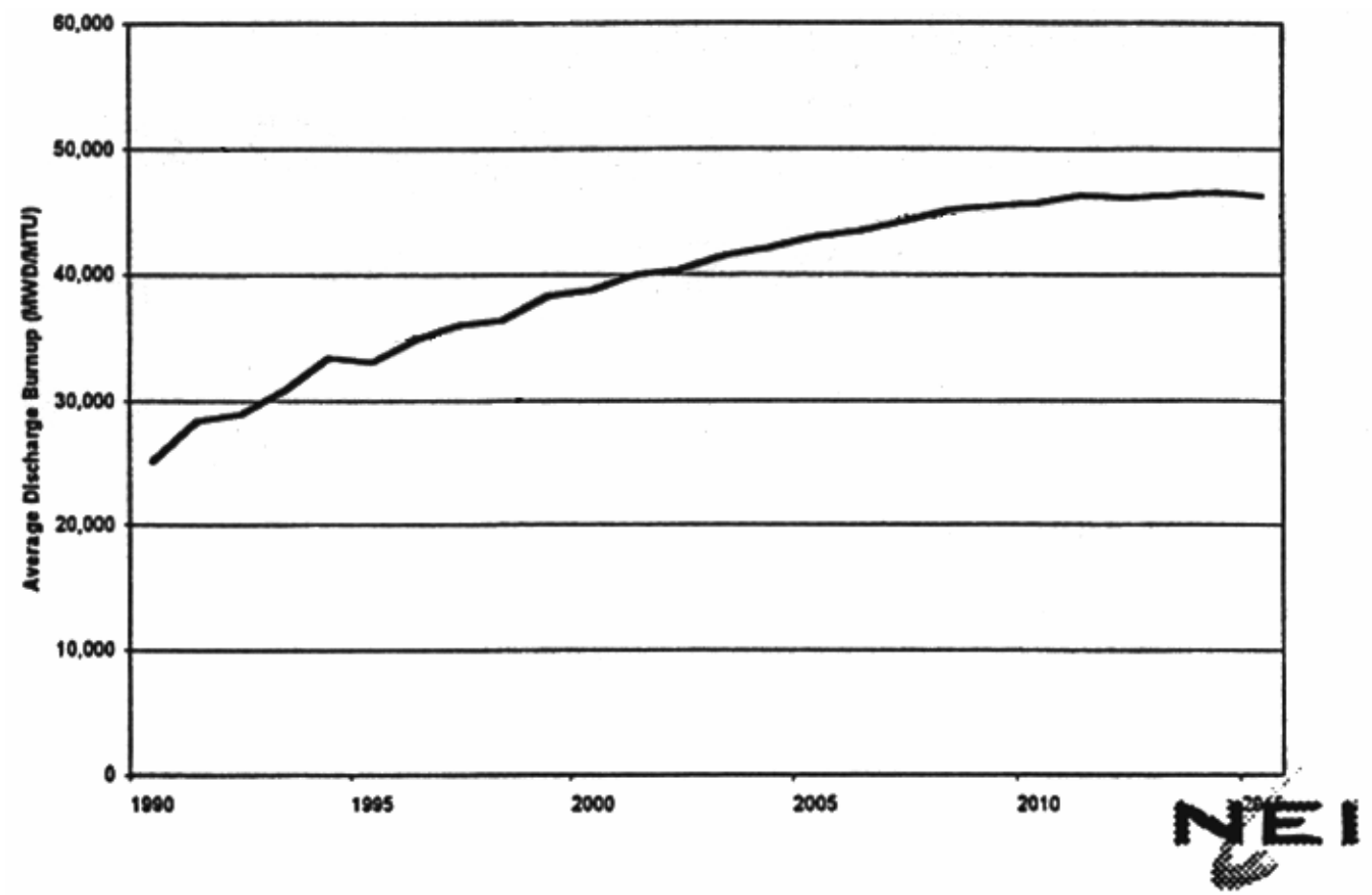

Figure 2-3

Historical and Projected Discharge Burnup Trend for BWRs (Beedle 1999) 


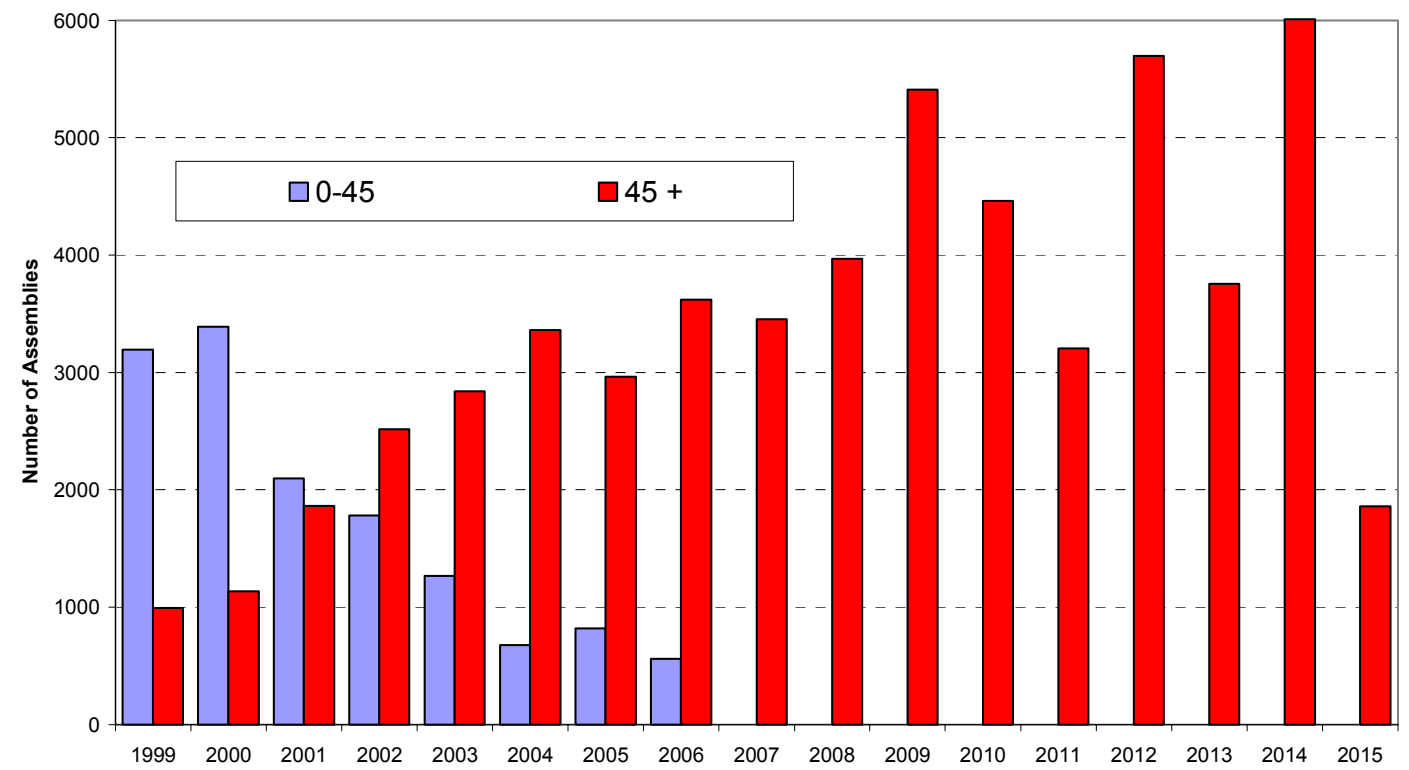

Figure 2-4

Projected Number of Discharged BWR Fuel Assemblies with Burnup Levels Below and Above 45 GWd/MTU (Gruss 2002) [originally generated by E. Supko for NEI]

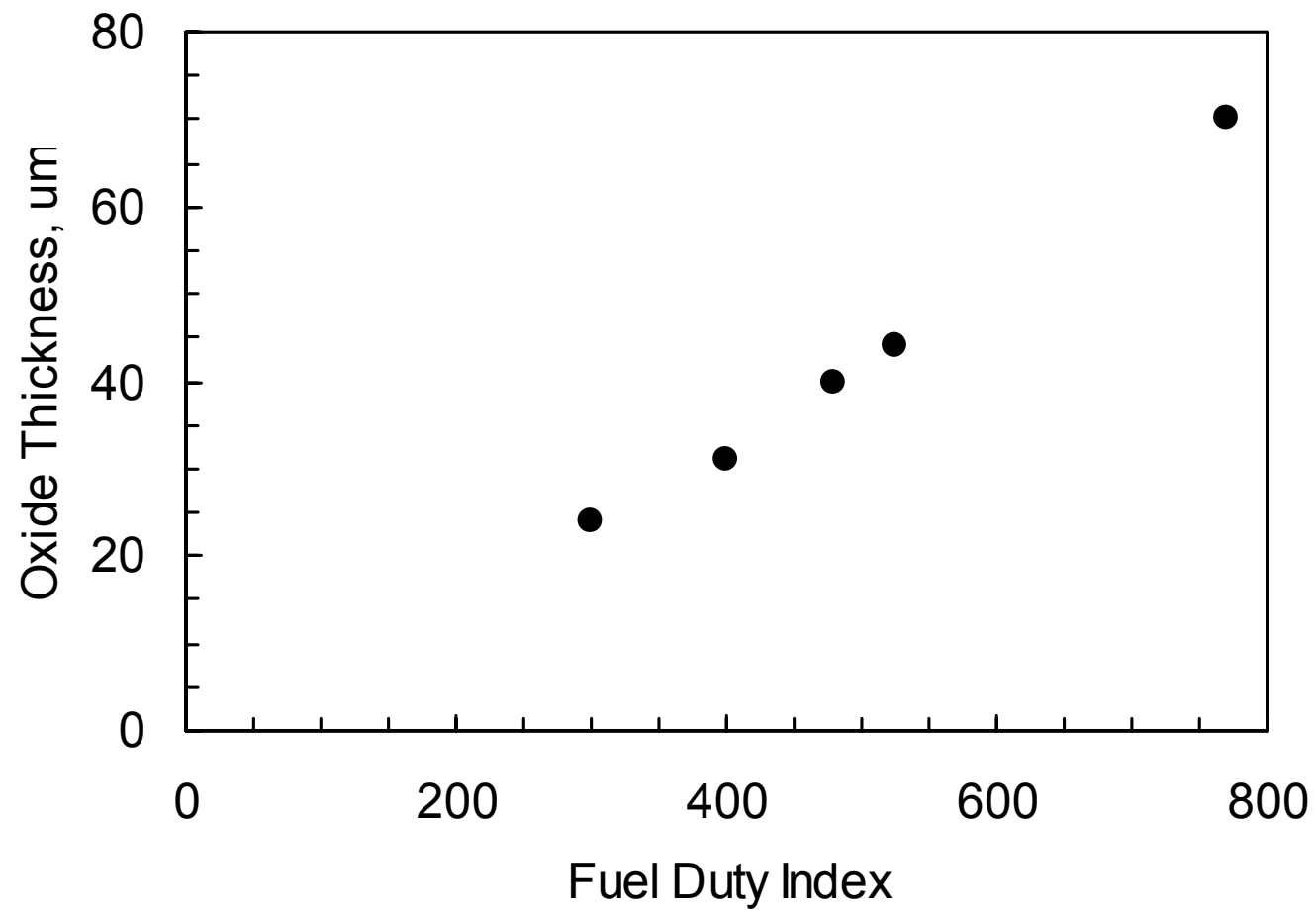

Figure 2-5

Illustration of Effect of Duty Cycle on Fuel Performance. All data points taken at a burnup of $66 \mathrm{GWd} / \mathrm{MTU}$ (Knott et al. 2003). 


\subsection{Prior Cask Demonstration Programs}

As a result of the Nuclear Waste Policy Act of 1982, DOE, in cooperation with the private sector, entered into demonstration programs of spent fuel dry storage. From 1982 through 1992, several performance tests and demonstrations were conducted by DOE (McKinnon and Deloach 1993) through cooperative agreements with EPRI, Carolina Power and Light, Virginia Power, Wisconsin Electric Power Company, Lawrence Livermore National Laboratory, Idaho National Engineering and Environment Laboratory, Los Alamos National Laboratory, and Sierra Nuclear Corporation.

Performance tests were conducted on the Gesellshaft für Nuklear Service CASTOR-V/21 (Creer et al. 1986), Transnuclear TN-24P, and Westinghouse MC-10 metal storage casks and on the NUHOMS and Sierra Nuclear ventilated concrete storage systems (McKinnon and Deloach 1993). A separate performance test was conducted by DOE at General Electric's Morris Operations on an REA-2023 metal storage cask (McKinnon et al. 1986). The CASTOR V/21, Nuclear Assurance NAC-I28, and Westinghouse MC-10 casks were also demonstrated at Virginia Power's Surry reactor site ISFSI.

Various levels of design-specific thermal and shielding analyses were performed before the performance tests to predict the thermal and shielding performance of the various storage systems. The performance tests started with loading the casks with spent nuclear fuel assemblies. This was followed with instrumenting the casks to determine internal and external temperature and surface dose rates. Testing was performed with vacuum, nitrogen, and helium backfill environments in both vertical and horizontal cask orientations. Limited spent fuel integrity data were obtained through gas sampling and analysis.

The primary objective of the PWR spent fuel storage cask performance testing was to obtain heat transfer and shielding data as well as the limited spent fuel integrity data needed to support atreactor licensing. The tests confirmed that the storage systems could be satisfactorily handled and loaded dry. They also demonstrated the heat transfer and shielding performance of the systems when loaded with intact or consolidated PWR spent fuel.

The fuel used in the cask performance tests at INEEL came from two sources (McKinnon and Deloach 1993). A brief summary of the fuel is provided in the Table 2-1. This fuel had burnup levels significantly lower than the spent fuel that is being discharged currently.

Table 2-1

Fuel Used in Prior Dry Storage System Demonstrations

\begin{tabular}{|l|l|l|}
\hline & \multicolumn{1}{|c|}{ BWR Fuel } & \multicolumn{1}{c|}{ PWR Fuel } \\
\hline Reactor & Cooper & Surry and Turkey Point \\
\hline Assembly Type & GE $7 \times 7$ & Westinghouse $15 \times 15$ \\
\hline Burnup Range & $24-28$ GWd/MTU & $24-35$ GWd/MTU \\
\hline
\end{tabular}


After the performance testing was completed, the CASTOR V/21 cask was left loaded with 21 PWR assemblies for 14.2 years (1985-1999). In 1999, in support of the technical basis for license and Certificate of Compliance renewal for dry storage systems, examinations began of the condition and integrity of the storage pad, the exterior and interior surfaces of the CASTOR V/21 cask, and its contents (Kimball and Billone 2003). The results indicated that the storage pad, cask, and cask contents exhibited sound structural and seal integrity and that long-term (14-year) storage had not caused detectable degradation of the spent fuel cladding or a release of gaseous fission products. When the fuel assemblies were removed from the cask and examined, there was no detectable degradation or apparent creep or bow. The force required to remove the assemblies from the cask basket indicated little sticking. There was also no evidence of cladding creep based on the ease of removing the rods from the fuel assembly structure. The fuel assemblies were reloaded into the CASTOR V/21 cask, where they will be stored until the repository opens.

A fuel assembly with a burnup of $35.7 \mathrm{GWd} / \mathrm{MTU}$ and close to the highest storage temperature was selected for the greatest amount of post-storage examination. The temperature history for this assembly included a peak temperature of $415^{\circ} \mathrm{C}$ during the cask thermal testing (vacuum drying simulation) and a temperature of $350^{\circ} \mathrm{C}$ at the beginning of the 14-year storage period (helium cover gas). Twelve rods from the assembly were selected for nondestructive examinations conducted at ANL-W; three of these rods were subsequently shipped to ANL-E for destructive examinations. Conclusions on the post-storage condition of the Surry rods were partly based on comparisons with data obtained from similar rods irradiated in the Turkey Point reactor that had not been dry stored. ${ }^{(3)}$ Principal observations from the post-test examinations on this fuel assembly and the selected fuel rods include the following:

- Post-storage gas pressure and fission gas release were 3.4 to $3.6 \mathrm{MPa}$ (at $300 \mathrm{~K}$ ) and 0.4 to $1.0 \%$, respectively. These values are within the expected end-of-irradiation value range for fuel of this vintage and burnup; thus it was concluded that there was negligible fission gas release during the storage period.

- Apparent cladding creep-down during the reactor operation was $\sim 0.6 \%$, and there was little or no apparent outward creep during the storage period.

- Based on cladding hardness data, there was apparently negligible annealing of irradiation damage during the storage period.

- Post-storage cladding oxide thicknesses were 20 to $40 \mu \mathrm{m}$ and hydrogen concentrations 250 to $300 \mathrm{ppm}$. These are within expectations for end-of-irradiation conditions. All observed hydrides were circumferential with no apparent radial reorientation.

- Creep tests were performed on some cladding samples. These tests indicated that the cladding had residual creep strain $>1 \%$ at $380^{\circ}(220 \mathrm{MPa})$ and $400^{\circ} \mathrm{C}(190 \mathrm{MPa})$.

- Except for microhardness and creep, no other cladding mechanical property was measured.

(3) Post-dry storage examination of the Surry rods was not anticipated at the start of the dry storage demonstration program in 1985; thus only limited pre-dry storage information was available for the Surry rods to compare with the results obtained after 14-years of dry storage. 
In conclusion, the 14-year storage period for these Surry rods with burnup levels less than $40 \mathrm{GWd} / \mathrm{MTU}$ had negligible effect on the condition of the spent fuel.

\subsection{Irradiation Effects and Burnup/Exposure Dependency}

Irradiation effects and subsequent impacts on the spent fuel cladding due to dry storage are important because the cladding provides the initial barrier to the release of radioactive material to the environment and contributes to maintaining the configuration of the fuel. This fuel configuration has been postulated in the thermal, shielding, and criticality analyses. If credit is to be taken for the cladding, there needs to be assurance that it will remain intact during storage and transportation. Therefore, it is important to know how the cladding of high-burnup fuel behaves during dry storage and transportation.

During irradiation in a light-water reactor (LWR), the cladding is subjected to two principal effects. First, neutron bombardment causes radiation damage to the cladding microstructure, which changes the mechanical properties of the cladding (i.e., reduces ductility and increases strength). Second, exposure to the high-temperature water causes waterside oxidation of the cladding. This oxidation reduces the wall thickness of the cladding. Also, the cladding picks up a fraction of the hydrogen generated during the oxidation process. Hydrogen in the cladding can cause embrittlement. Irradiation damage of the cladding is the primary contributor to the reduced ductility with the presence of hydrides as a secondary contributor. Both of these effects increase with burnup level. Oxidation and hydrogen pickup are strongly temperature dependent. Irradiation damage can be annealed out of the cladding if temperatures are sufficiently high.

The reduction in ductility due to radiation damage appears to be synergistically affected by localized hydride concentration, distribution, and orientation. In Zircaloy, because (i) hydrogen migrates down a temperature gradient when the temperature and temperature gradient are sufficiently large and (ii) the solubility of hydrogen in Zircaloy increases with temperature, hydrogen migrates to and precipitates out at local cold spots. This results in higher concentrations of hydrides at pellet interfaces, at the cladding periphery in contact with the coolant, and, if present, in the proximity of spalled oxide regions. Stress field may also contribute to the migration of hydrogen to areas of higher stress values, but to a much smaller extent.

The mechanical properties of the cladding are dependent on the orientation of the hydride platelets in the cladding and on the properties of the irradiated metallic Zircaloy matrix phase. Analysis of the hydrided cladding strength is further complicated by the lack of properties for irradiated zirconium hydride, bond strength between the hydride and the base metal, and the dynamic nature of the precipitate (Garde et al. 1996).

Post-irradiation (PIE) or post-test examinations of irradiated fuel have typically been conducted for two major reasons: first to evaluate the in-reactor performance of the fuel. These data are used for model and computer code development and fuel design optimization; they also provide pre-storage conditions. A substantial number of these examination campaigns have been conducted. Second, there are post-test examinations for evaluating post-irradiation storage performance. These represent a much smaller data base, an example of which is the examination of the Surry fuel after 14 years of dry storage. 
An example of a major post-irradiation characterization program is work that was performed in the late 1980s to characterize spent fuel that was selected to be representative of the typical range of spent fuel at end-of-life fuel conditions. The emphasis on acquiring this fuel and performing the related examinations were driven by geologic disposal, not interim dry storage. The approved testing material (ATM) included PWR fuel rods with a burnup range of 16 to 44 $\mathrm{GWd} / \mathrm{MTU}$ and BWR fuel rods with a burnup range of 15 to $34 \mathrm{GWd} / \mathrm{MTU}$. The fuel characterization was performed to support investigations of spent nuclear fuel geologic disposal (Barner 1985; Guenther et al. 1988a, 1988b, 1991a, 1991b, 1994), and the examinations emphasized the fuel material and chemical characterization (e.g., fuel dissolution, fission product leaching, fuel oxidation) and not characteristics more relevant to interim dry storage (e.g., cladding condition). The ATMs are briefly compared in Table $2-2$. The burnup levels of $\sim 40$ $\mathrm{GWd} / \mathrm{MTU}$ were considered high for the ATM program, while high burnup today is generally considered to be greater than $50 \mathrm{GWd} / \mathrm{MTU}$.

At the time of the characterization program, ATM-103 was selected as representative of PWR fuel with moderate burnup with an average burnup of $30 \mathrm{GWd} / \mathrm{MTU}$. ATM-104 and ATM-106 were PWR fuel that had moderately high burnup of about $43 \mathrm{GWd} / \mathrm{MTU}$. ATM-104 was expected to have low fission gas release, and ATM-106 was expected to have a fission gas release of about $10 \%$. ATM-105 was from a BWR fuel with burnups around $28 \mathrm{GWd} / \mathrm{MTU}$. In addition to characterizing the fuel, the examination results provided a database of information that was used to validate analyses used to predict composition of the spent fuel.

The characterization of the ATMs included fission gas release, fission gas analyses (xenon, krypton, and carbon-14), gamma scans, fuel radiochemistry, cladding radiochemistry, analytical transmission electron microscopy, fuel ceramography and autoradiography, and cladding metallography. No characterization of cladding oxidation or irradiation-induced dimensional changes or testing of cladding mechanical properties was performed.

This work, like the cask demonstrations, was performed with spent fuel that had high burnup levels by the standards of its day. However, the burnup levels achieved at the time the analyses were completed are significantly below the burnup levels being obtained today. 
Table 2-2

Comparison of ATMs

\begin{tabular}{|c|c|c|c|c|c|}
\hline & ATM-101 & ATM-103 & ATM-104 & ATM-105 & ATM=106 \\
\hline Report & $\begin{array}{l}\text { PNL-5109, Rev. } 1 \\
\text { Barner } 1985\end{array}$ & $\begin{array}{l}\text { PNL-5109-103 } \\
\text { Guenther et al. 1988a }\end{array}$ & $\begin{array}{l}\text { PNL-5109-104 } \\
\text { Guenther et al. 1991b }\end{array}$ & $\begin{array}{l}\text { PNL-5109-105 } \\
\text { Guenther et al. 1991a }\end{array}$ & $\begin{array}{l}\text { PNL-5109-106 } \\
\text { Guenther et al. } \\
\text { 1988b }\end{array}$ \\
\hline $\begin{array}{l}\text { Characterization of } \\
\text { ATM }\end{array}$ & $\begin{array}{l}\text { Medium Burnup, } \\
\text { Low Fission Gas } \\
\text { Release }\end{array}$ & $\begin{array}{l}\text { Medium Burnup, } \\
\text { Low Fission Gas } \\
\text { Release }\end{array}$ & $\begin{array}{l}\text { High Burnup, } \\
\text { Low Fission Gas } \\
\text { Release }\end{array}$ & $\begin{array}{l}\text { Medium Burnup, } \\
\text { Low Fission Gas } \\
\text { Release }\end{array}$ & $\begin{array}{l}\text { High Burnup, } \\
\text { High Fission Gas } \\
\text { Release }\end{array}$ \\
\hline $\begin{array}{l}\text { Fuel Type } \\
\text { Source Reactor }\end{array}$ & $\begin{array}{l}\text { PWR } \\
\text { HB Robinson \#1 }\end{array}$ & $\begin{array}{l}\text { PWR } \\
\text { Calvert Cliffs \#1 }\end{array}$ & $\begin{array}{l}\text { PWR } \\
\text { Calvert Cliffs \#1 }\end{array}$ & $\begin{array}{l}\text { BWR } \\
\text { Cooper }\end{array}$ & $\begin{array}{l}\text { PWR } \\
\text { Calvert Cliffs \#1 }\end{array}$ \\
\hline Assembly No. & & D101 & D047 & CZ346, CZ348 & BT03 \\
\hline No. of Rods in ATM & 9 as 4-ft Segments & 176 Full-Length & 128 Full-Length & 88 Full-Length & 20 Full-Length \\
\hline $\begin{array}{l}\text { Rod-Average Burnup } \\
\text { of Rods in ATM }\end{array}$ & 30 GWd/MTU & 30 GWd/MTU & 〜2 GWd/MTU & 28 GWd/MTU & 43 GWd/MTU \\
\hline $\begin{array}{l}\text { Rod-Average Fission } \\
\text { Gas Release }\end{array}$ & $<1 \%$ & $<1 \%$ & $\sim 1 \%$ & $\sim 1 \%$ & $\sim 10 \%$ \\
\hline Fuel Manufacturer & Westinghouse & $\begin{array}{l}\text { Combustion } \\
\text { Engineering }\end{array}$ & $\begin{array}{l}\text { Combustion } \\
\text { Engineering }\end{array}$ & General Electric & $\begin{array}{l}\text { Combustion } \\
\text { Engineering }\end{array}$ \\
\hline
\end{tabular}




\subsubsection{Review of Current Fuel Discharge Conditions/Trends}

Post-irradiation examinations of fuel continue to be performed for obtaining data to support licensing of the fuel designs to higher burnup levels, understand the changes that occur with increasing burnup, and/or support material and design changes. Regular technical meetings are held on the subject of fuel performance. Premier among these meetings has been the triennial international topical meeting sponsored by the American Nuclear Society on light-water reactor fuel performance (ANS 1997, 2000; ENS 2003). Data on fuel performance has also been regularly presented at the NRC's annual Water Reactor Safety Meeting (now called the Nuclear Reactor Safety Conference); these meetings have recently focused on the performance of fuel under in-reactor accident conditions (NRC 2002b).

Provided in the following paragraphs are brief reviews of representative examination programs and other insights into current fuel performance and trends.

- The Robust Fuel Program (RFP) managed by EPRI began in 1998. One of the major objectives of this program is to conduct examinations of fuel driven to high burnup under high-duty conditions. The results of these examinations will be used to confirm margin adequacy and allow for increases in burnup or duty without unacceptable erosion in margins. To achieve time and cost savings, the RFP has identified available fuel that could meet its needs rather than starting from new lead test assemblies for future examination. In addition, the RFP has identified gaps where emphasis is needed: fuel with burnup levels greater than $62 \mathrm{GWd} / \mathrm{MTU}$, new fuel designs (such as BWR 10x10 assemblies), modern cladding materials (such as Zirlo ${ }^{\mathrm{TM}}$ and M5), and fuel operated under today's high-duty cycles (i.e., higher coolant temperatures, extended cycles). The fuel of interest to the RFP is also of interest to the potential spent fuel storage demonstration because that fuel is representative of what is now being irradiated and may be considered "bounding" with regard to burnup and fuel duty cycle.

- The High Burnup Effects Program was an international research program that focused on obtaining well-characterized data related to fission gas release for fuel irradiated to high burnup levels (Barner et al. 1990). Fuel was both acquired and fabricated for this program with peak rod-average burnups of $69 \mathrm{GWd} / \mathrm{MTU}$. The program's focus was on fuel performance. There was no mechanical analysis or testing of the cladding.

- Argonne National Laboratory-East (ANL-E) is conducting experimental work for the NRC, which is generating mechanical properties data on irradiated cladding, loss-of-coolant accident oxidation and ballooning, and dry storage creep. This work is in progress, and not all results have been reported. The cladding being investigated was obtained from Limerick BWR, HB Robinson PWR, and Three Mile Island PWR (Tsai and Billone 2002). The Limerick fuel is from a 9x9 assembly with rod-average burnup of $56 \mathrm{GWd} / \mathrm{MTU}$. This fuel had fission gas release of 5 to $17 \%$, oxide layers averaging $10 \mu \mathrm{m}$, and hydrogen concentration of $70 \mathrm{wppm}$ hydrogen. Twelve rods were acquired from $15 \times 15$ assemblies irradiated in the HB Robinson PWR; rod-average burnup is 64 to $67 \mathrm{GWd} / \mathrm{MTU}$. This fuel had fission gas release of $<5 \%$, oxide layers up to $110 \mu \mathrm{m}$, and hydrogen concentration of up to $850 \mathrm{wppm}$. Two rods are from the Three Mile Island-1 PWR. These rods have rod-average 
burnup of $50 \mathrm{GWd} / \mathrm{MTU}$ and oxide layers $<30 \mu \mathrm{m}$. The Surry PWR rods discussed above (burnup $=36 \mathrm{GWd} / \mathrm{MTU}$ ) are also at ANL-E.

- Fuel examination campaigns are occasionally conducted at the reactor in the spent fuel pool. Typically these examinations consist of visual examinations, eddy current measurement of oxide thickness, rod diameter, and occasionally measurement of $\mathrm{Kr}-85$ activity in the plenum to infer fission gas release. An example examination is reported by Ruzauskas and Fardell (2001).

- PWR fuel is continually being operated under increasing fuel duty requirements. These higher duty conditions include higher-energy core designs, higher-temperature coolant, peaking factor increases, extended fuel burnup, and modified coolant chemistry. A term now being used is "fuel duty," which refers to the operating conditions of the fuel over time (Knott et al. 2003). The factors captured in the fuel duty concept include heat flux, irradiation exposure, time at temperature, and coolant chemistry. The use of fuel duty can help to discriminate fuel rod in-reactor performance. An example provided by Knott et al. (2003) is oxide thickness (Figure 2-5). At a burnup level of $66 \mathrm{GWd} / \mathrm{MTU}$, oxide thickness varies from 20 to $70 \mu \mathrm{m}$ but is shown to be dependent on fuel duty: increasing oxide thickness correlates to increasing fuel duty (i.e., increased operating temperature).

The condition of the fuel at the end of the irradiation sets the initial conditions for the dry storage period. Cladding creep is dependent on both the cladding mechanical properties and the differential pressure across the cladding. The internal rod pressure during dry storage is dependent on the fission gas release and the fuel temperature during storage. The cladding mechanical properties, necessary to resist creep and impact loads, are dependent on irradiation damage, oxidation and hydrogen loading (hydride quantity and orientation), etc.

Fission gas release generally increases with burnup but is truly dependent on power and fuel temperature. Provided in Figure 2-6 is an illustration of the broad range of in-reactor fission gas release that has been observed for PWR-type rods. The top of the band is representative of some German data obtained from rods held at higher power during irradiation (Manzel and Walker 2003). The bottom of the band is representative of some French data obtained from rods held at lower power levels (Morel et al. 1994). It is important to note the broad range of possible fission gas release (and thus internal gas pressure). For example, the Surry rods used at INEEL were at the lower edge of the band.

Similar to fission gas release, cladding oxidation can be presented as a function of burnup as illustrated in Figure 2-7. This figure is based on data from Kaiser et al. (2000). To again illustrate the effect of fuel duty cycle, these data are plotted as a function of fuel duty index in Figure 2-8. It may be seen that the range of oxide thickness values is considerably greater than for the Surry fuel and increases with burnup and fuel duty index.

Based on the material presented above, it is proposed that considerations for selecting spent fuel for a confirmatory dry storage demonstration program should include rod-average burnup $\geq 60 \mathrm{GWd}$ /MTU, high-duty-cycle fuel with higher oxide and hydrogen levels (deterioration of mechanical properties), and higher fission gas release and internal rod pressure levels (creep). 


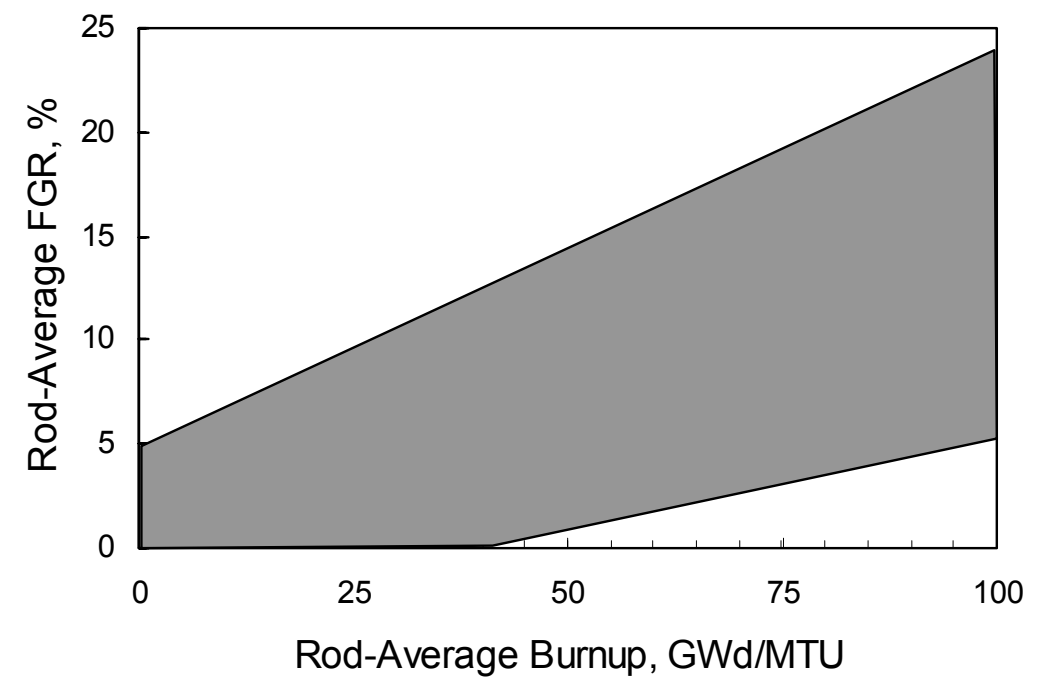

Figure 2-6

Illustration of Range of Observed Fission Gas Release Values. Fission gas release is primarily dependent on operating fuel temperatures.

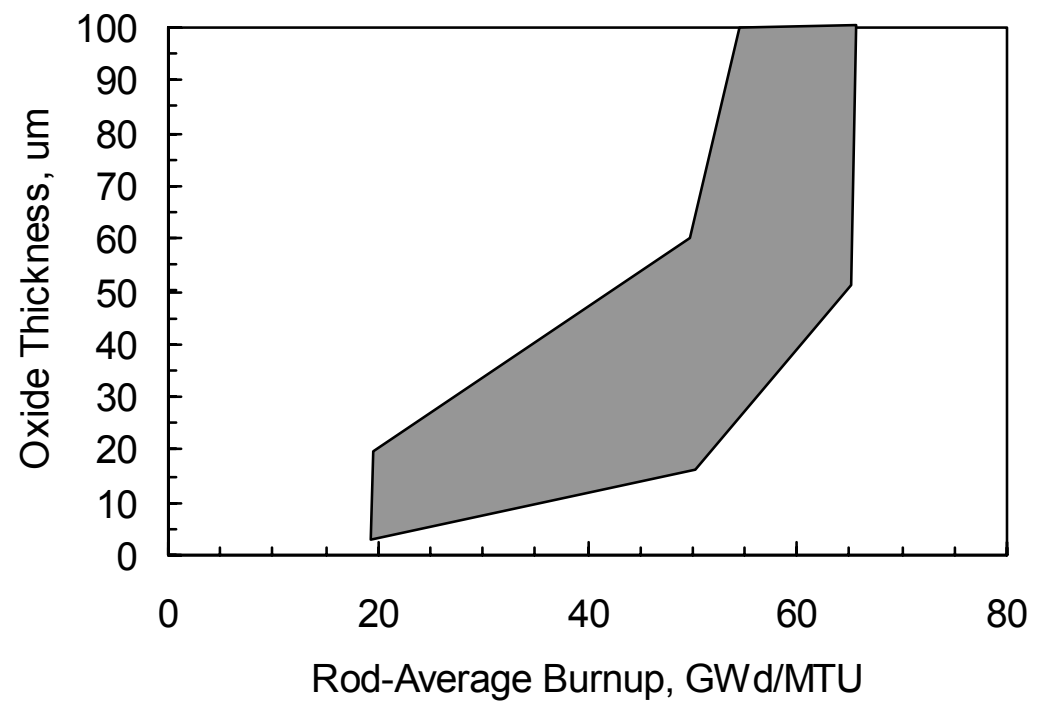

Figure 2-7

Illustration of Range of Observed Cladding Oxide Thickness (Kaiser 2000). Oxidation is primarily dependent on exposure time, cladding temperature, and coolant chemistry.

The selected fuel for the confirmatory program should be as bounding as possible rather than from a wide selection of fuel burnups, duty cycles, oxide thicknesses, and hydrogen levels. 


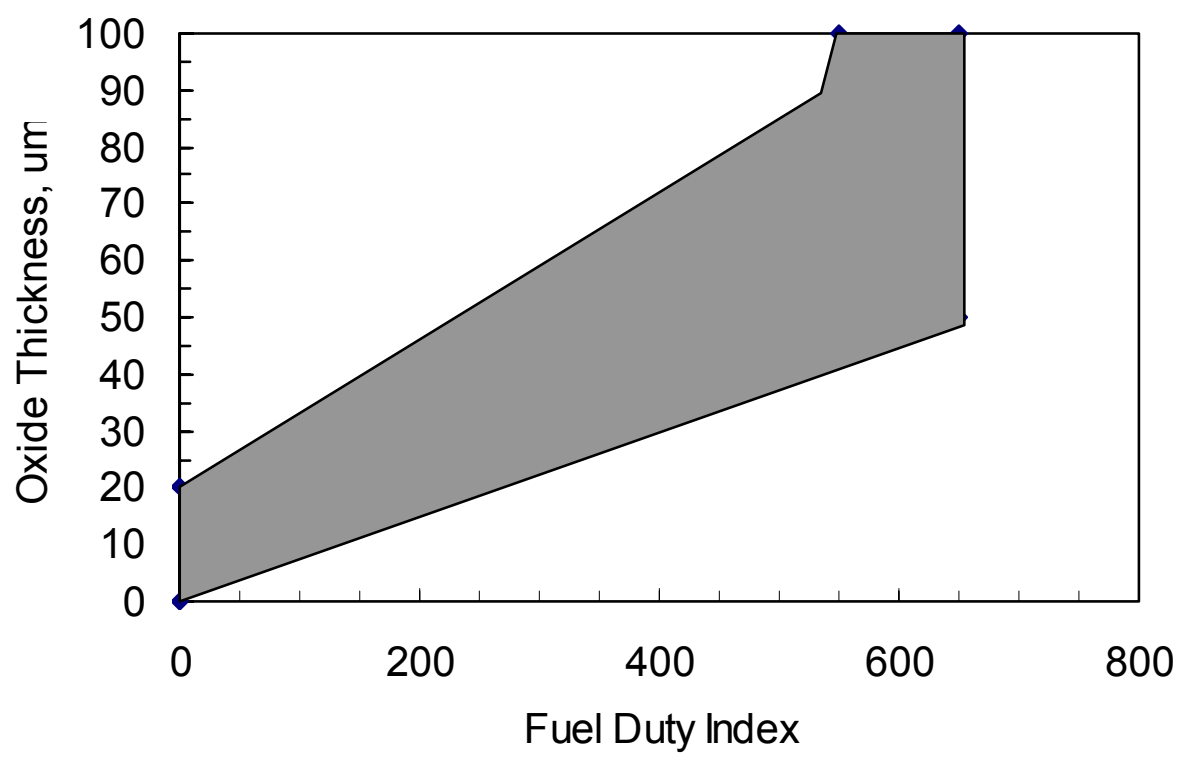

Figure 2-8

Cladding Oxide Thickness as a Function of Duty Cycle (Kaiser 2000)

\subsection{Cask Characterization}

The cask or canister containing the spent fuel provides the final barrier between the spent fuel and the public. Considering the robust nature of the storage system and the relative low neutron fluences it sees during storage, it probably will not be affected by radiation damage and would be expected to easily endure the storage period without damage. However, characterizing the cask or canister prior to loading should be relatively easy and inexpensive. It would be prudent to perform this characterization to allow meaningful post-storage characterization of the storage container. The post-storage examination of the cask or canister should also be relatively easy to perform at the time the cask or canister is opened for removal of spent fuel rods. Cask or canister examination would ensure its ability to maintain the fuel in the analysis configuration for the duration of storage and subsequent transportation to a repository. The validity of the thermal, shielding, and criticality calculations is dependent on the ability of the canister/cask to maintain the fuel configuration used in the analyses and on the ability of the materials used in the canister or cask to maintain their properties for the duration of storage and transportation. However, given the relatively short storage duration of the demonstration program (nominally five years), few if any generic data are expected to be obtained on the cask components. 


\section{3 \\ RESOURCES}

This study investigated the four primary components needed to successfully accomplish a confirmatory demonstration program:

- a dry storage demonstration site

- a source of representative/bounding spent fuel

- destructive and nondestructive fuel examination capabilities

- a dry storage system.

The resources available to supply these components include the following:

- Utilities with existing ISFSIs as potential demonstration sites and as sources of spent fuel.

- National laboratories as possible demonstration sites and fuel examination sites for pre- and post-test fuel examinations and characterization.

- Fuel vendors for poolside nondestructive examination of the spent fuel.

- Cask vendors for dry storage systems modified for temperature, gas sampling, and fuel removal capabilities. The storage cask/canister should be characterized prior to testing to provide a baseline for possible post-storage cask characterization.

The results of soliciting potential sources to provide the components are discussed in the following sections.

\subsection{Demonstration Sites and High-Burnup Fuel Sources}

Two sources for demonstration sites were selected for consideration in the study: a utility with an existing ISFSI and a national laboratory. A demonstration site needs to be capable of placing the spent fuel into the demonstration dry storage system, monitoring the fuel temperatures and cask fill gas, and then retrieving the spent fuel for post-test examination. The utilities would be the sources for the high-burnup spent fuel.

\subsubsection{Utilities}

The locations of operating ISFSIs and potential near-term new ISFSIs in the United States are shown in Figures 3-1 and 3-2, respectively. Six operating utilities were contacted to determine their interest in participating in a demonstration program. 


\section{Operating SPEnt Fuel Storage Sites (ISFSI)}

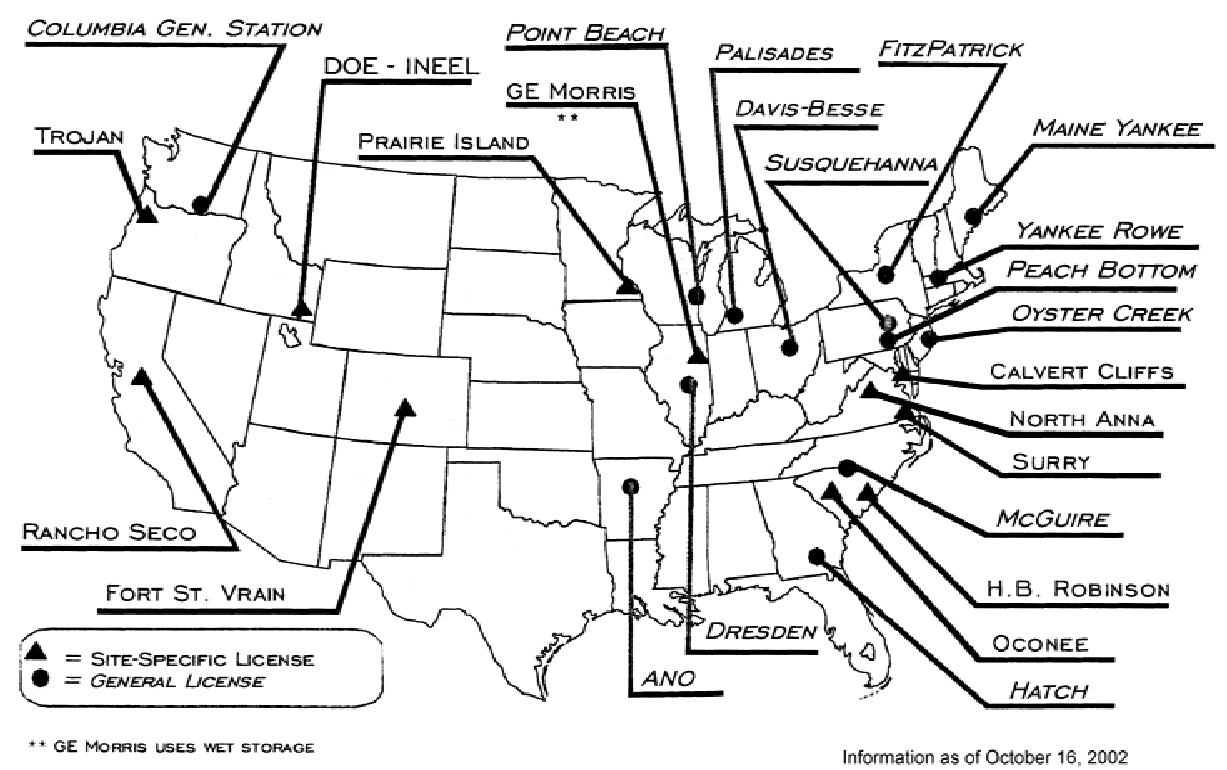

Figure 3-1

Location of Operating ISFSIs (Brach 2003)

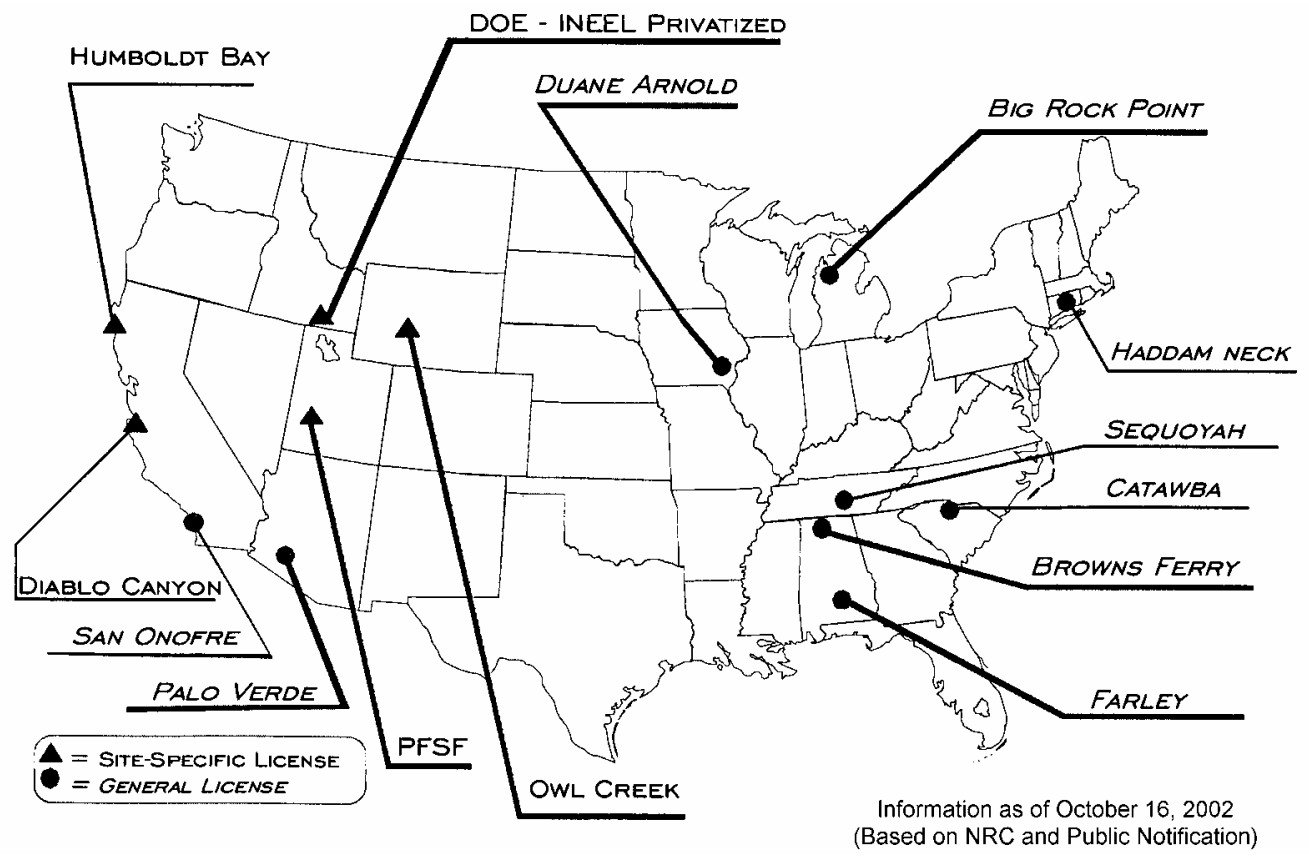

Figure 3-2

Potential Near-Term ISFSIs (Brach 2003) 
Each utility representative was asked if they would be interested in participating in a demonstration project at their ISFSI and under what conditions. Each of the utility representatives was also asked about the highest burnup of their fuel, cladding materials in use, ability to remove individual pins, spent fuel storage system(s) in use, and willingness to monitor cask temperatures and cover gas. The utilities, contact person, and responses are summarized in Table 3-1. In addition to the utilities listed in Table 3-1, two additional utilities were contacted: Energy Northwest was contacted by a national laboratory and Arkansas Nuclear One by a fuel vendor.

A couple of the utility contacts were enthusiastic about participating in the high-burnup dry storage demonstration. Several of the contacts were concerned that involvement in the program could delay ongoing activities of their own to address characterization of high-burnup spent fuel. Most indicated that funds would need to be provided to compensate them for their involvement. All were enthusiastic about providing fuel assemblies for the demonstration, provided they could transfer the fuel and ownership of the fuel to DOE. They universally stated that when the fuel left their site it would become the property of whoever takes it. Most of the utilities contacted have or will soon have fuel with burnups that would support the demonstration.

Initially, the storage systems considered for the demonstration were limited to those with bolted lids - all-metal casks. These systems were appealing from the perspective that the lids could be easily modified and removed to facilitate instrumentation of the cask basket, drawing gas samples, and removing fuel. Canister systems were perceived to be more challenging for instrumentation or reopening for fuel removal. But most of the utilities are now loading canister-based dry storage systems. Only a limited number of utilities are still using all-metal cask systems, and these utilities are considering transitioning to canister-based systems in the near future. Hence, the canister-based systems were also considered in the study, recognizing that the canister would become expendable after being cut open for fuel removal. Once the lid is cut off the canister cannot be reused so would be discarded after the fuel is removed at the end of the dry storage demonstration. The remaining fuel would need to be returned to the spent fuel pool or to another canister. Opening and disposing of the canister represent additional work for the demonstration site, but the work might not be prohibitive because utilities with canister systems are required to have the capability to repackage the fuel as part of their license.

\subsubsection{National Laboratories}

Selected DOE national laboratories (ANL-E, ANL-W, INEEL, Oak Ridge National Laboratory [ORNL], Pacific Northwest National Laboratory [PNNL], and Savannah River Site [SRS]) were contacted and asked to respond to a survey about their interest in serving as a demonstration site and providing fuel examination services for the potential demonstration project. Written responses to the survey questionnaire were provided by ANL-W, INEEL, ORNL, PNNL, and SRS' Savannah River Technical Center (SRTC). The laboratories were asked about available facilities, expertise, and experience in receiving and handling spent nuclear fuel. In addition, the laboratories were asked about other issues that would be relevant to their serving as the demonstration site or providing fuel examination services (see Section 3.2.2). All laboratories indicated interest in serving as the demonstration site and in providing fuel examination services. 
Table 3-1

Summary of Information Received from Utilities

\begin{tabular}{|c|c|c|}
\hline Utility & Constellation Energy Group & Dominion \\
\hline Person Contacted & Robert H. Beall & Tom Brookmire \\
\hline Power Plant & Calvert Cliffs & North Anna, Surry \\
\hline $\begin{array}{l}\text { Interest in } \\
\text { Participating in a } \\
\text { Demonstration }\end{array}$ & $\begin{array}{l}\text { Most definitely as long as it does not } \\
\text { delay or interfere with their own program } \\
\text { to characterize high-burnup spent fuel. }\end{array}$ & \\
\hline $\begin{array}{l}\text { Conditions for } \\
\text { Participation }\end{array}$ & $\begin{array}{l}\text { Will be looking for some financial } \\
\text { compensation for their involvement. }\end{array}$ & \\
\hline $\begin{array}{l}\text { Fuel Type and } \\
\text { Burnup }\end{array}$ & $\begin{array}{l}\text { CE } 14 \times 14 \text { (Westinghouse), } \\
60 \mathrm{GWd} \text { (MTU for peak pin, } \\
55-57 \mathrm{GWd} \text { /MTU average. They have a } \\
\text { few assemblies in the mid } 60 \text { s. }\end{array}$ & $\begin{array}{l}\text { PWR. } 62 \text { GWd/MTU pins, high } 50 \text { s for } \\
\text { bundles. They will be inserting some } \\
\text { LTAs into North Anna for irradiation to } \\
\text { burnups in the } 70 \text { s. }\end{array}$ \\
\hline $\begin{array}{l}\text { Cladding Materials } \\
\text { to Be Used }\end{array}$ & $\begin{array}{l}\text { Currently using low-tin Zircaloy. } \\
\text { They inserted } 8 \text { lead test assemblies in } \\
\text { their core }(2 / 03): 4 \text { with M5 cladding and } \\
4 \text { with Zirlo cladding. }\end{array}$ & \\
\hline \multicolumn{3}{|l|}{ Fuel Supplier } \\
\hline $\begin{array}{l}\text { Able to Remove } \\
\text { Fuel Pins }\end{array}$ & Yes. & \\
\hline $\begin{array}{l}\text { Current Fuel } \\
\text { Characterization } \\
\text { Programs }\end{array}$ & $\begin{array}{l}\text { Plan to push burnup to } 70 \mathrm{GWd} / \mathrm{MTU} \\
\text { over an eight-year period. May send } \\
\text { selected rods to Chalk River for analysis } \\
\text { at the end of irradiation. Perform NDE } \\
\text { exams at poolside on a regular basis. }\end{array}$ & \\
\hline $\begin{array}{l}\text { Dry Storage System } \\
\text { in Use }\end{array}$ & $\begin{array}{l}\text { NUHOMS, currently using } 24 \text {-assembly } \\
\text { baskets. Plan to go to } 32 \text {-assembly } \\
\text { baskets. Their constraint is heat loading } \\
\text { of the canisters. }\end{array}$ & \\
\hline $\begin{array}{l}\text { Instrumentation of } \\
\text { System }\end{array}$ & $\begin{array}{l}\text { Would require interaction with NRC for } \\
\text { internal temperatures and gas sampling. } \\
\text { External temperature measurements } \\
\text { would be relatively easy to do. }\end{array}$ & \\
\hline Disposal Costs & $\begin{array}{l}\text { If the canister were modified for the } \\
\text { demonstration, it would be disposed of } \\
\text { as low-level waste afterward. }\end{array}$ & \\
\hline Fuel Ownership & $\begin{array}{l}\text { If fuel leaves the site, it does not come } \\
\text { back, and ownership is transferred. }\end{array}$ & \\
\hline
\end{tabular}


Table 3-1

(continued)

\begin{tabular}{|c|c|c|}
\hline Utility & Duke Power & Xcel \\
\hline Person Contacted & $\begin{array}{l}\text { David Jones, Stanley Hayes, Gary } \\
\text { Walden }\end{array}$ & Max DeLong, Jon Kapitz \\
\hline \multicolumn{3}{|l|}{ Power Plant } \\
\hline $\begin{array}{l}\text { Interest in } \\
\text { Participating in a } \\
\text { Demonstration }\end{array}$ & $\begin{array}{l}\text { Probably not interested in being a } \\
\text { demonstration site because of head- } \\
\text { aches getting licensing approval for a } \\
\text { cask demonstration. May be interested } \\
\text { in supplying fuel depending on availability } \\
\text { of personnel and equipment. }\end{array}$ & $\begin{array}{l}\text { Would be interested in participating } \\
\text { depending on how it would help move } \\
\text { spent fuel from their site. }\end{array}$ \\
\hline \multicolumn{3}{|l|}{$\begin{array}{l}\text { Conditions for } \\
\text { Participation }\end{array}$} \\
\hline $\begin{array}{l}\text { Fuel Type and } \\
\text { Burnup }\end{array}$ & PWR. 60 GWd/MTU. & $\begin{array}{l}\text { Burnup in mid } 50 \text { s, peak pin in low } 60 \text { s. } \\
\text { One LTA with burnup of } \sim 70 \text { GWd/MTU. } \\
\text { Westinghouse will NDE the fuel in } 2004 \text {. } \\
\text { The fuel has been irradiated for three } \\
\text { two-year cycles. }\end{array}$ \\
\hline $\begin{array}{l}\text { Cladding Materials } \\
\text { to Be Used }\end{array}$ & $\begin{array}{l}\text { Oconee has low tin Zircaloy with } \\
\text { corrosion levels as high as } 106 \text { micron. } \\
\text { Zirlo and M5 cladding recently intro- } \\
\text { duced. It is at low burnup and won't be } \\
\text { available for a while. }\end{array}$ & \\
\hline Fuel Supplier & Framatome & \\
\hline $\begin{array}{l}\text { Able to Remove } \\
\text { Fuel Pins }\end{array}$ & $\begin{array}{l}\text { Not enthusiastic about exams in their } \\
\text { pools because of the intense planning } \\
\text { involved, which takes plant personnel } \\
\text { away from performing everyday duties. }\end{array}$ & \\
\hline \multicolumn{3}{|l|}{$\begin{array}{l}\text { Current Fuel } \\
\text { Characterization } \\
\text { Programs }\end{array}$} \\
\hline $\begin{array}{l}\text { Dry Storage System } \\
\text { in Use }\end{array}$ & & $\begin{array}{l}\text { PWR. TN-40 at Prairie Island. Expect to } \\
\text { move to dual-purpose canisters soon. } \\
\text { Site-specific license, PFS in Utah: } \\
\text { canistered fuel (Holtec). }\end{array}$ \\
\hline \multicolumn{3}{|l|}{$\begin{array}{l}\text { Instrumentation of } \\
\text { System }\end{array}$} \\
\hline \multicolumn{3}{|l|}{ Disposal Costs } \\
\hline Fuel Ownership & $\begin{array}{l}\text { Would be happy to get rid of some spent } \\
\text { fuel assemblies. }\end{array}$ & $\begin{array}{l}\text { If fuel is moved from site, ownership goes } \\
\text { with it. Would not be willing to accept } \\
\text { fuel from another site. }\end{array}$ \\
\hline
\end{tabular}


Table 3-1

(continued)

\begin{tabular}{|c|c|c|}
\hline Utility & Entergy & Exelon \\
\hline Person Contacted & Darryl Williams & Matt Eyre \\
\hline \multicolumn{3}{|l|}{ Power Plant } \\
\hline $\begin{array}{l}\text { Interest in } \\
\text { Participating in a } \\
\text { Demonstration }\end{array}$ & $\begin{array}{l}\text { Willing to support demonstration } \\
\text { program as long as changes are small. } \\
\text { The program would have to be } \\
\text { negotiated with upper management. }\end{array}$ & $\begin{array}{l}\text { Yes, they have been trying to get } \mathrm{DOE} \\
\text { and NEl interested. }\end{array}$ \\
\hline $\begin{array}{l}\text { Conditions for } \\
\text { Participation }\end{array}$ & Funding. & $\begin{array}{l}\text { Funds would have to be provided to } \\
\text { cover costs associated with procedural } \\
\text { changes or cask modifications. }\end{array}$ \\
\hline $\begin{array}{l}\text { Fuel Type and } \\
\text { Burnup }\end{array}$ & B\&W and C-E Fuel. & BWR. 47 to $52 \mathrm{GWd} / \mathrm{MTU}$. \\
\hline $\begin{array}{l}\text { Cladding Materials } \\
\text { to Be Used }\end{array}$ & $\begin{array}{l}\text { Zircaloy cladding. Not planning on } \\
\text { using M5 or Zirlo cladding in the near } \\
\text { future. }\end{array}$ & $\begin{array}{l}\text { BWRs use Zircaloy-2; PWRs use } \\
\text { improved Zircaloy- } 4 \text {. Will move to M5 } \\
\text { with Framatome fuel and to Zirlo with } \\
\text { Westinghouse fuel. }\end{array}$ \\
\hline \multicolumn{3}{|l|}{ Fuel Supplier } \\
\hline $\begin{array}{l}\text { Able to Remove } \\
\text { Fuel Pins }\end{array}$ & & Yes. \\
\hline $\begin{array}{l}\text { Current Fuel } \\
\text { Characterization } \\
\text { Programs }\end{array}$ & & $\begin{array}{l}\text { They will pull rods for poolside inspec- } \\
\text { tion at Limerick in December } 2003 \text {, } \\
65 \text { GWD/MTU. Rods will be punctured } \\
\text { at Vallecitos. }\end{array}$ \\
\hline $\begin{array}{l}\text { Dry Storage } \\
\text { System in Use }\end{array}$ & $\begin{array}{l}\text { Currently using the VSC- } 24 \text {. Plan to } \\
\text { transition to Holtec design. }\end{array}$ & $\begin{array}{l}\text { TN-68 at Peach Bottom ( } 15 \text { loaded }) \text {. } \\
\text { Limited to } 3.6 \text { wt } \% \text { in initial U- } 235 \\
\text { enrichment. High-burnup fuel may } \\
\text { exceed cask's licensing limit. } \\
\text { NUHOMS } 61-B T \text { at Oyster Creek } \\
\text { ( } 4 \text { loaded }) . \text { Holtec at Dresden } \\
(\sim 12 \text { loaded). }\end{array}$ \\
\hline $\begin{array}{l}\text { Instrumentation of } \\
\text { System }\end{array}$ & $\begin{array}{l}\text { Would require modification to the } \\
\text { general license. }\end{array}$ & \\
\hline \multicolumn{3}{|l|}{ Disposal Costs } \\
\hline Fuel Ownership & Would need to be worked out. & Ownership changes at site boundary. \\
\hline & & $\begin{array}{l}\text { Have been using NAC LWT to get rods } \\
\text { to the hot cell for examination. }\end{array}$ \\
\hline
\end{tabular}


To serve as the demonstration site, it is expected that a national laboratory would need to be able to perform a number of functions. The necessary functions include the ability to receive spent fuel from another source, place the spent fuel into another cask, monitor the cask temperatures and backfill gas composition (assuming that the cask has been modified for this activity), retrieve spent fuel for post-test examination, and dispose of the spent fuel and the storage cask at the end of the demonstration project.

The responses provided by the laboratories to the survey questionnaire prepared by PNNL are provided in the appendix. The laboratory responses to questions about serving as the potential demonstration site are summarized in Table 3-2 and briefly discussed in the following subsections. It is apparent that INEEL, in conjunction with ANL-W, currently have the most capable facilities for handling the full-length fuel assemblies, dealing with the storage and transportation casks, and performing many of the desired post-test fuel examinations (see Section 3.2.2). However, concerns/issues are also evident with the INEEL/ANL-W combination, particularly the issue of being able to receive and then disposition the commercial spent fuel needed for this demonstration project. The other national laboratories apparently have fewer issues in dealing with commercial spent fuel but would need to put additional capabilities into place to deal with the storage and transportation casks, transloading the full-length fuel, performing examinations on full-length fuel rods, etc.

\subsubsection{ANL-W}

ANL-W is located at INEEL and proposed using their Hot Fuels Examination Facility (HFEF) for the demonstration. ANL-W provided two proposals for performing the demonstration. The first would use a truck-mounted transportation cask system positioned in a weather enclosure. This would require using only one spent fuel assembly and no significant additional equipment or hardware. The second proposal was based on using a full-scale storage cask. This would require special transfer equipment for loading/unloading activities. In addition, a pad would need to be constructed to accommodate the cask.

Other points related to using ANL-W for the demonstration site include the following abilities:

- receive truck-mounted casks but not rail-mounted casks

- obtain portable heavy-lift equipment when needed

- analyze cask cover gases, but casks would need to be modified so gas samples could be collected

- make arrangements to either re-assign the cask or decontaminate and dispose of it. 
Table 3-2

Summary of National Laboratory Responses about Serving as Demonstration Site

\begin{tabular}{|c|c|c|c|c|c|}
\hline Question & ANL-W & INEEL & ORNL & PNNL & SRTC \\
\hline Contact & $\begin{array}{l}\text { David S. Duncan } \\
\text { david.duncan@anl.gov } \\
\text { (208) 533-7847 }\end{array}$ & $\begin{array}{l}\text { Thomas J. Hill } \\
\text { tih@inel.gov } \\
\text { (208) 526-1711 }\end{array}$ & $\begin{array}{l}\text { Donald Spellman } \\
\text { spellmandj@ornl.gov } \\
\text { (865) 574-7891 }\end{array}$ & $\begin{array}{l}\text { John Abrefah } \\
\text { john.abrefah@pnl.gov } \\
(509) \text { 373-0927 }\end{array}$ & $\begin{array}{l}\text { Mark Dupont } \\
\text { mark.dupont@srs.gov } \\
\text { (803) 725-0954 }\end{array}$ \\
\hline $\begin{array}{l}\text { Interested in } \\
\text { Having the } \\
\text { Demonstration } \\
\text { Site }\end{array}$ & - Yes & - Yes & - Yes & $\begin{array}{l}\text { - Yes; alone or in } \\
\text { conjunction with } \\
\text { Energy Northwest (EN) }\end{array}$ & - Yes \\
\hline $\begin{array}{l}\text { Any Potential } \\
\text { Conflicts of } \\
\text { Interest }\end{array}$ & - No & - No & - No & - No & - No \\
\hline $\begin{array}{l}\text { General Site } \\
\text { Characteristics }\end{array}$ & $\begin{array}{l}\text { - HFEF can receive } \\
\text { commercial spent } \\
\text { fuel shipping casks } \\
\text { - Can handle full- } \\
\text { length assemblies } \\
\text { and rods } \\
\text { - HFEF is an inert-gas } \\
\text { hot cell with low } \\
\text { alpha contamination } \\
\text { - Propose using NAC- } \\
\text { LWT cask that is left } \\
\text { on a trailer and } \\
\text { provided with } \\
\text { weather protection }\end{array}$ & $\begin{array}{l}\text { - Propose TAN } \\
\text { - Hot shop with } 110 \mathrm{t} \\
\text { overhead crane; } 51^{\prime} \mathrm{W} \\
\text { by } 165^{\prime} \text { L by } 55^{\prime} \mathrm{H} \\
\text { - Outside dry cask } \\
\text { storage pad with } \\
\text { hookups for monitoring } \\
\text { pressure and } \\
\text { temperature } \\
\text { - Bridge and wall- } \\
\text { mounted remote } \\
\text { manipulators } \\
\text { - Water storage pool } \\
\text { - Fuel is shipped to ANL } \\
\text { for destructive exams }\end{array}$ & $\begin{array}{l}\text { - Existing or new pad at } \\
\text { HFIR site for the cask } \\
\text { - HFIR site has nuclear } \\
\text { operations compatible } \\
\text { and similar to spent } \\
\text { fuel operations } \\
\text { - Mobile cranes range } \\
\text { from } 15 \mathrm{~T} \text { to } 75 \mathrm{~T}\end{array}$ & $\begin{array}{l}\text { - RPL is Category II } \\
\text { nuclear facility for } \\
\text { examinations of } \\
\text { irradiated materials } \\
\text { - EN's Columbia } \\
\text { Generating Station has } \\
\text { concrete pads and } \\
\text { spent fuel pool for fuel } \\
\text { transfer } \\
\text { - Hanford's } 200 \text { and } 400 \\
\text { Areas for possible } \\
\text { storage and fuel } \\
\text { transfers }\end{array}$ & $\begin{array}{l}\text { - Site for receipt/ } \\
\text { storage of domestic } \\
\text { and international } \\
\text { research reactor spent } \\
\text { fuel } \\
\text { - CSX rail access } \\
\text { - } 120 \text {-ton building crane } \\
\text { - } 100 \text {-ton portable } \\
\text { cranes } \\
\text { - Concrete storage pads }\end{array}$ \\
\hline
\end{tabular}


Table 3-2

(continued)

\begin{tabular}{|c|c|c|c|c|c|}
\hline Question & ANL-W & INEEL & ORNL & PNNL & SRTC \\
\hline $\begin{array}{l}\text { Existing Inventory } \\
\text { of Spent Fuel }\end{array}$ & $\begin{array}{l}\text { - See INEEL } \\
\text { response }\end{array}$ & $\begin{array}{l}\text { - Onsite fuel is only } 30 \text { to } \\
35 \mathrm{GWd} / \mathrm{MTU}\end{array}$ & $\begin{array}{l}\text { Currently have on-site } \\
\text { research quantities of } \\
\text { BWR fuel and legacy } \\
\text { spent fuel from past } \\
\text { research projects }\end{array}$ & $\begin{array}{l}\text { - EN may have } \\
\text { applicable fuel at the } \\
\text { time of the } \\
\text { demonstration project }\end{array}$ & $\begin{array}{l}\text { - Spent fuel from } \\
\text { research and test } \\
\text { reactors }\end{array}$ \\
\hline $\begin{array}{l}\text { Can Arrange } \\
\text { Transportation }\end{array}$ & $\begin{array}{l}\text { Experienced with } \\
\text { NAC-LWT shipping } \\
\text { cask and others (T- } \\
\text { 3, T-2, TN-FSV, } \\
\text { NRBK-41, WAPD- } \\
\text { 40) }\end{array}$ & $\begin{array}{l}\text { - Have arranged multiple } \\
\text { spent fuel shipments }\end{array}$ & $\begin{array}{l}\text { Yes; have experience } \\
\text { shipping sections of } \\
\text { irradiated fuel and on- } \\
\text { site movement of } \\
\text { HFIR cores }\end{array}$ & $\begin{array}{l}\text { - Yes; expertise in } \\
\text { shipping spent fuel and } \\
\text { TRU } \\
\text { - Team from EN would } \\
\text { handle shipping spent } \\
\text { fuel to their site }\end{array}$ & $\begin{array}{l}\text { Extensive experience } \\
\text { with movement of } \\
\text { spent fuel and casks }\end{array}$ \\
\hline $\begin{array}{l}\text { Fuel Receipt } \\
\text { Abilities }\end{array}$ & $\begin{array}{l}\text { - Able to receive } \\
\text { truck shipping } \\
\text { casks }\end{array}$ & $\begin{array}{l}\text { - Can receive rail and } \\
\text { truck casks } \\
\text { - Demonstrated ability to } \\
\text { transload fuel using } \\
\text { TAN hot shop } \\
\text { - } 140 \text {-ton mobile cask } \\
\text { transporter }\end{array}$ & $\begin{array}{l}\text { - Can handle full-length } \\
\text { assemblies in large } \\
\text { hot cell near HFIR, but } \\
\text { full-length rods only at } \\
\text { Irradiated Fuels Exam- } \\
\text { ination Laboratory } \\
\text { (IFEL) } \\
\text { - Can transload from } \\
\text { shipping to storage } \\
\text { cask and transfer cask } \\
\text { to hot cells }\end{array}$ & $\begin{array}{l}\text { - EN spent fuel pool } \\
\text { could be used given } \\
\text { exemption/license } \\
\text { amendment by NRC } \\
\text { - No dry transfer system } \\
\text { to move spent fuel } \\
\text { from storage to } \\
\text { examination facilities }\end{array}$ & $\begin{array}{l}\text { - One cask receiving } \\
\text { basin that can handle } \\
\text { full-length commercial } \\
\text { assemblies } \\
\text { - Experience } \\
\text { transloading research } \\
\text { fuel } \\
\text { - Building access is } \\
20 \mathrm{ft} \text { tall by } 18 \mathrm{ft} \text { wide; } \\
\text { crane clearance } \\
>30 \mathrm{ft} \text { vertical }\end{array}$ \\
\hline $\begin{array}{l}\text { Analyses of Gas } \\
\text { from Cask }\end{array}$ & $\begin{array}{l}\text { - Yes, gamma } \\
\text { analysis and mass } \\
\text { spectrometry }\end{array}$ & $\begin{array}{l}\text { - Capability in place for } \\
\text { monitoring storage } \\
\text { casks already at TAN }\end{array}$ & $\begin{array}{l}\text { - Fully functional } \\
\text { capabilities used on a } \\
\text { routine basis }\end{array}$ & $\begin{array}{l}\text { - Yes; using capabilities } \\
\text { of RPL }\end{array}$ & $\begin{array}{l}\text { - Mass spectrometry, } \\
\text { gamma spectroscopy, } \\
\text { gas chromatography } \\
\text { - Experience with in-situ } \\
\text { gas analysis systems } \\
\text { - Experience with gas } \\
\text { collection systems }\end{array}$ \\
\hline
\end{tabular}




\begin{tabular}{|c|c|c|c|c|c|}
\hline Question & ANL-W & INEEL & ORNL & PNNL & SRTC \\
\hline $\begin{array}{l}\text { Restrictions on } \\
\text { Receiving and } \\
\text { Accepting } \\
\text { Commercial } \\
\text { Spent Fuel }\end{array}$ & $\begin{array}{l}\text { - The Idaho Settle- } \\
\text { ment Agreement } \\
\text { controls receipt of } \\
\text { commercial spent } \\
\text { fuel in Idaho. } \\
\text { - Before beginning } \\
\text { the project, would } \\
\text { ask DOE to estab- } \\
\text { lish terms for SNF } \\
\text { receipt and accept- } \\
\text { ance with Idaho. }\end{array}$ & $\begin{array}{l}\text { - The Idaho Settlement } \\
\text { Agreement controls } \\
\text { receipt of commercial } \\
\text { spent nuclear fuel in } \\
\text { the State of Idaho. } \\
\text { - Before beginning the } \\
\text { project, would request } \\
\text { DOE to establish terms } \\
\text { for SNF receipt and } \\
\text { acceptance with Idaho. }\end{array}$ & $\begin{array}{l}\text { - Responsibility can be } \\
\text { accepted if a waste } \\
\text { products strategy has } \\
\text { been developed and } \\
\text { approved by DOE }\end{array}$ & $\begin{array}{l}\text { - Receipt of spent fuel at } \\
\text { Hanford will require } \\
\text { DOE approval } \\
\text { - EN license may require } \\
\text { exemption or } \\
\text { amendment by NRC }\end{array}$ & $\begin{array}{l}\text { - No known restrictions } \\
\text { - Formal approval of } \\
\text { authorizing authorities } \\
\text { would be necessary }\end{array}$ \\
\hline $\begin{array}{l}\text { How to Dispose } \\
\text { of Spent Fuel at } \\
\text { End of Project }\end{array}$ & $\begin{array}{l}\text { Before beginning } \\
\text { the project, would } \\
\text { request DOE to } \\
\text { accept ownership } \\
\text { responsibility } \\
\text { based on terms of } \\
\text { Idaho Settlement } \\
\text { Agreement. }\end{array}$ & $\begin{array}{l}\text { - Before beginning the } \\
\text { project, would request } \\
\text { DOE to accept owner- } \\
\text { ship responsibility } \\
\text { based on terms of the } \\
\text { Idaho Settlement } \\
\text { Agreement. }\end{array}$ & $\begin{array}{l}\text { - No approved path in } \\
\text { place at this time } \\
\text { - Arrangements would } \\
\text { need to be developed } \\
\text { and approved by DOE } \\
\text { - Can be stored at } \\
\text { SWSA awaiting } \\
\text { disposal. }\end{array}$ & $\begin{array}{l}\text { - DOE accepts owner- } \\
\text { ship of fuel; add fuel to } \\
\text { Hanford inventory } \\
\text { - Spent fuel will then be } \\
\text { in same disposal } \\
\text { pathway with eventual } \\
\text { disposal in geologic } \\
\text { repository } \\
\text { - If approved, the spent } \\
\text { fuel and cask may be } \\
\text { stored in } 200 \text { Area } \\
\text { awaiting disposal }\end{array}$ & $\begin{array}{l}\text { DOE-owned SNF at } \\
\text { SRS will be transferred } \\
\text { to the proposed } \\
\text { geologic repository } \\
\text { - Disposition of spent } \\
\text { fuel would need to be } \\
\text { negotiated }\end{array}$ \\
\hline $\begin{array}{l}\text { What do with } \\
\text { Storage Cask } \\
\text { after Demon- } \\
\text { stration is } \\
\text { Completed }\end{array}$ & $\begin{array}{l}\text { - Depending on cask } \\
\text { used, options in- } \\
\text { clude transferring } \\
\text { ownership to DOE, } \\
\text { decontamination } \\
\text { and scraping, } \\
\text { and/or disposing as } \\
\text { low-level waste }\end{array}$ & $\begin{array}{l}\text { - Unless another need is } \\
\text { identified, INEEL could } \\
\text { decontaminate, } \\
\text { dismantle, and dispose } \\
\text { of the cask }\end{array}$ & $\begin{array}{l}\text { - Use cask for } \\
\text { subsequent } \\
\text { experiments or } \\
\text { dispose in a manner } \\
\text { similar to that planned } \\
\text { by commercial users } \\
\text { of casks }\end{array}$ & $\begin{array}{l}\text { - Bury as low-level } \\
\text { waste at Hanford if not } \\
\text { used to ship spent fuel } \\
\text { to geologic repository }\end{array}$ & $\begin{array}{l}\text { - Enough facilities to } \\
\text { retain the cask } \\
\text { - Cask could be made } \\
\text { available for other } \\
\text { uses }\end{array}$ \\
\hline
\end{tabular}


Table 3-2

(continued)

\begin{tabular}{|c|c|c|c|c|c|}
\hline Question & ANL-W & INEEL & ORNL & PNNL & SRTC \\
\hline $\begin{array}{l}\text { Specific Window } \\
\text { of Opportunity or } \\
\text { Periods when } \\
\text { Work Could Not } \\
\text { Be } \\
\text { Accommodated }\end{array}$ & $\begin{array}{l}\text { - No; the proposed } \\
\text { work would be } \\
\text { planned and } \\
\text { scheduled into } \\
\text { HFEF operations } \\
\text { - Limited to } 5 \text { year } \\
\text { project by Idaho } \\
\text { Agreement }\end{array}$ & $\begin{array}{l}\text { - New projects are being } \\
\text { sought for TAN } \\
\text { - Limited to } 5 \text {-year } \\
\text { project by Idaho } \\
\text { Agreement. }\end{array}$ & $\begin{array}{l}\text { - Facilities underutilized } \\
\text { - Preliminary review of } \\
\text { work schedules did } \\
\text { not identify any } \\
\text { conflicts with other } \\
\text { planned projects }\end{array}$ & $\begin{array}{l}\text { - No identified periods } \\
\text { when proposed work } \\
\text { could not be } \\
\text { accommodated } \\
\text { - EN schedule would } \\
\text { dictate when facilities } \\
\text { could be used to } \\
\text { support proposed } \\
\text { project }\end{array}$ & $\begin{array}{l}\text { - This potential project is } \\
\text { not seen to impact } \\
\text { other work, or be } \\
\text { impacted by other } \\
\text { work }\end{array}$ \\
\hline $\begin{array}{l}\text { Any Proposed } \\
\text { Facilities } \\
\text { Scheduled for } \\
\text { Decommissioning }\end{array}$ & - No & $\begin{array}{l}\text { - Ownership of TAN } \\
\text { being transferred from } \\
\text { DOE-EM to -NE; the } \\
\text { future mission of TAN } \\
\text { is being defined }\end{array}$ & No & $\begin{array}{l}\text { - Tentative agreement } \\
\text { with DOE-RL to keep } \\
\text { RPL open until } 2028 \text { to } \\
\text { support Hanford } \\
\text { cleanup }\end{array}$ & $\begin{array}{l}\text { - One of three basins is } \\
\text { scheduled for de- } \\
\text { inventory and closure } \\
\text { by } 2006\end{array}$ \\
\hline
\end{tabular}


The Idaho Settlement Agreement places significant controls on the receipt, use, and disposal of spent fuel. Currently, the agreement requires a disposal path for the spent fuel and only allows a five-year residency time for new spent fuel coming into the state. ANL-W would require DOE to accept ownership responsibility for the spent fuel.

\subsubsection{INEEL}

The INEEL proposed using their TAN facility, which has ongoing demonstration programs involving dry storage of spent fuel. A DOE/NRC program placed instrumented spent fuel in several dry storage cask designs. Measurements of spent fuel temperatures and external radiation fields provided data used to verify predictive computer codes. The TAN facility includes the Warm Shop, Hot Shop, hot cells, a storage pool, and storage cask testing pad. The dry cask storage pad already exists with hookups for monitoring cask conditions.

Other points related to using TAN for the demonstration site include the following:

- Ability to receive both rail and truck casks

- Ability to transload spent fuel assemblies in the Hot Shop

- Existing 140-ton mobile cask transporter ${ }^{(4)}$

- Six dry storage casks on site: MC-10, REA-2023, VSC-17, TN-24P, GNS CASTOR V/21, and NuPac 125B

- Onsite fuel, in the above dry storage casks, with burnup levels only up to $35 \mathrm{GWd} / \mathrm{MTU}$ (Surry and Turkey Point spent fuel used in the earlier cask performance demonstration) (see Table 2-1)

- Ability to decontaminate, dismantle, and dispose of cask(s) at end of the demonstration

- Ability to collect and analyze the cask cover gas in place because of existing dry storage casks

- Ability to perform fuel examinations in cooperation with ANL-W.

The Idaho Settlement Agreement places significant controls on the receipt, use, and disposal of spent fuel. INEEL would require DOE to accept ownership responsibility for the spent fuel. The future of TAN is indeterminate while management of INEEL transitions from DOE-EM to DOE$\mathrm{NE}$ and the future of the facility is reviewed.

\subsubsection{ORNL}

ORNL proposed using the High Flux Isotope Reactor (HFIR) site for the cask location because the HFIR site has operations compatible with and similar to spent fuel storage operations. The fuel examinations would be conducted in the Irradiated Fuels Examination Laboratory (IFEL),

(4) The cask transporter is adequate to move loaded casks but does not have the size or load capacity to move production sized vertical concrete storage modules. 
which is not now capable of handling full-length rods or assemblies. ORNL has committed to an upgrade project at IFEL to replace an overhead crane and build a mating device for the NAC LWT cask. This upgrade will give ORNL full-length rod capability by June 2004. ORNL also supplied a proposal (see appendix) to load selected rods into small containers for the proposed demonstration project. These small containers could then be easily shipped in a NAC-LWT cask and stored in a NLI cask that is available at ORNL. This would also reduce the number of rods involved in the proposed demonstration project. However, it would lower the radiation field seen by the fuel during dry storage, and, more importantly, would require the fuel or canister to be heated to the desired temperatures.

Other points related to using ORNL for the demonstration site include the following:

- No commercial spent fuel is currently on site.

- Full-length assemblies can be handled in a large hot cell near HFIR, but only full-length rods can be handled at the IFEL when the upgrades are completed in June 2004.

- Mobile cranes are available with capacities up to 75 tons.

- The capability exists to analyze cask cover gases, but, as with all the national laboratory sites, casks would need to be modified so gas samples could be collected.

- ORNL facilities are under-utilized, and no conflicts with other planned projects are envisioned.

\subsubsection{PNNL}

PNNL, teaming with Energy Northwest's Columbia Generating Station, proposed using available concrete pads at the Columbia Generating Station or Hanford's 200 Area for the storage cask. The Radiochemical Processing Laboratory (RPL) would be used for the fuel examinations. Energy Northwest may have BWR spent fuel with the burnup characteristics of interest, depending on when the proposed demonstration project might be started. PNNL could also run a demonstration program independent of the Columbia Generating Station if an NAC NLI cask were procured.

Other points related to using PNNL and Energy Northwest for the demonstration site include:

- The spent fuel pool at the Columbia Generating Station could be used to receive and transload full-length fuel assemblies and rods because there is no dry transfer capability available to PNNL.

- NRC license amendments or variances would be needed for receiving offsite fuel in addition to DOE-RL approvals for the fuel examination work.

- The mass spectrometry laboratory in the RPL is well equipped for the necessary gas analyses on cask cover gases.

- The RPL has experience using the NAC-LWT shipping cask. 
- The fuel disposal pathway would need to be approved by DOE Richland Operations Office (RL), but the proposed pathway would be to add the spent fuel to the inventory of spent fuel at the Hanford site, which will ultimately go to geologic disposal.

- The storage cask could be disposed of as low-level waste at Hanford if not used for other purposes.

- Modifications would be necessary to the RPL to perform examinations on full-length fuel rods.

\subsubsection{SRS}

The Savannah River Technical Center (SRTC) at the SRS has extensive experience in receiving and storing domestic and foreign research reactor spent fuels. No commercial spent fuel is on site, but there are commercial reactors nearby. SRS has experience in dry transloading research spent fuel, which could be used to develop a dry transfer system for the commercial spent fuel.

Other points related to using SRS for the demonstration site include the following:

- There are no known restrictions for receiving commercial spent fuel, although requests would have to be made to authorizing agencies.

- Facilities include rail access, a 120-ton building crane and a 100-ton portable crane, cask decontamination facilities, and concrete storage pads.

- DOE-owned spent fuels at SRS will be transferred to the geologic repository.

- SRS has sufficient facilities to retain the storage cask or it could be made available for other uses.

- SRS has experience with collecting and analyzing radioactive gases and in designing in-situ gas analysis systems.

- Although SRS is busy with receiving research reactor spent fuels, no significant interference is foreseen with the proposed project.

- No project facility closings are expected to affect this proposed project.

\subsubsection{Common Laboratory Concerns}

Several common concerns/issues were raised by the national laboratories when considering the potential dry storage demonstration project. These issues/concerns are summarized in the following points:

- Storage/disposal of the demonstration spent fuel after completing the storage period and post-irradiation examinations. All national laboratories must have a plan in place to deal with the spent fuel before they can accept the spent fuel. Some laboratories may have specific agreements with local or state governments regarding materials that may be received. For example, INEEL/ANL-W have an agreement with the State of Idaho that spent fuel obtained for experimentation must leave Idaho within five years. The Hanford site 
(PNNL) has agreements in place related to cleanup that may affect receipt and disposal of commercial spent fuel. This is also tied in with the issue of ownership of the fuel: national laboratories will probably not accept ownership until the fuel is received on site, while the utilities will want to transfer ownership when the spent fuel leaves their site.

- Minimizing the quantity of spent fuel brought to the laboratory. All the national laboratories would prefer to minimize the quantity of spent fuel brought onto their sites. This has led them to recommend approaches that focus on the fuel performance aspect of the potential project. Focusing on the fuel performance can lead to a minimal number of fuel rods, stored at the bounding temperature in simulated storage conditions, rather than in a full-size storage cask that would require many full fuel bundles (typically 24 to 32 fuel bundles). This also would have the benefit of reducing costs associated with procuring/using a full-size storage cask. However, if it is determined that a major goal of the proposed demonstration project is investigating the performance of a storage cask filled with high-burnup spent fuel, this approach would not satisfy that goal.

- Transfer of the fuel between casks (shipping and storage) and hot cells. Dry transfers of the spent fuel between casks (shipping and storage) and hot cells for examination is a difficult problem for laboratories that are not currently able to receive full length spent fuel assemblies in commercial shipping casks. TAN, at INEEL, is currently the best equipped facility to accomplish this because of their large warm and hot shop facilities; however, the future of TAN and its availability through the duration of a possible demonstration project is not well defined at this time.

- Experience with shipping spent fuel. All the national laboratories have experience in shipping spent fuel of various types and conditions; however, much of this is generally done to DOE regulations rather than NRC regulations.

- Modifying storage cask for monitoring purposes. It may be assumed that the national laboratories would want to be involved in the plans for modifying casks for monitoring purposes, but they would expect the cask vendor to obtain any regulatory exemptions or license amendments.

- Cost. All respondents were very cautious about providing any cost estimates (for serving as either the demonstration site or providing the fuel examination services) because of the lack of details with regard to the scope of the dry storage phase (e.g., cask type, number of rods or assemblies, test time period, etc.), the fuel examinations to be conducted, and other operational issues (e.g., licensing, NEPA, waste disposal, etc.). The supplied cost estimates should be considered for order of magnitude only; also, they do not include the cost of acquiring and modifying a storage cask or many other costs associated with the potential project.

- ANL-W supplied two cost estimates: $\$ 7.5 \mathrm{M}$ if using a transport cask and $\$ 10.5 \mathrm{M}$ if using a storage cask. These estimates include periodic examinations of the fuel rods and final examination but do not include any facility upgrade costs or temporary storage costs.

- ORNL supplied a cost estimate of approximately $\$ 17 \mathrm{M}$ to serve as both demonstration and fuel examination site, based on the assumption the destructive PIE would be performed at project start, at 5 years, and at project completion at 10 years. No 
facility or equipment upgrade costs are needed. Cask modification, permitting, and waste storage and disposal costs were included.

- PNNL estimated costs in excess of $\$ 21 \mathrm{M}$ if dealing with a storage cask full of spent fuel or in excess of $\$ 15 \mathrm{M}$ if the storage demonstration was scaled down to just two fuel assemblies. These costs include the fuel examinations.

\subsection{Fuel Examination}

For the demonstration examination program to be successful, the fuel must be characterized before and after dry storage of the high-burnup spent fuel. Fuel examinations needed to characterize the spent fuel consist of nondestructive and destructive examinations. Most of the nondestructive examinations could be performed at the reactor pool prior to placing the highburnup fuel of interest into dry storage. Fuel vendors have the equipment and routinely perform fuel examinations. If sibling rods were set aside (kept in the reactor pool) at the beginning of dry storage, they could be re-examined with identical dry-stored rods at the end of the dry storage period to determine the effect of dry storage on the high-burnup spent fuel. At the conclusion of dry storage, both nondestructive and destructive examinations would be needed to determine any changes that may occur in the rods during dry storage.

\subsubsection{Fuel Vendors}

Fuel vendors routinely perform nondestructive exams of their fuel at utility sites. These inspections are used to identify failed fuel and to characterize intact fuel. The capabilities described in this subsection are based on information received from Framatome ANP, formerly Siemens (1996). Other fuel vendors have similar capabilities.

Failed fuel is identified using individual fuel rod eddy current testing, in-core sipping, vacuum sipping and ultrasonic testing. Eddy current testing is useful in locating cladding defects that can then be characterized using visual inspection techniques. Sipping identifies fuel assemblies having leaking fuel rods through analysis of coolant water or fission gases taken from a hood or container containing the fuel assembly. The sipping systems compare activity levels of four fission products $\left({ }^{131} \mathrm{I},{ }^{133} \mathrm{Xe},{ }^{134} \mathrm{Cs}\right.$, and $\left.{ }^{137} \mathrm{Cs}\right)$ with normal background levels as an indicator of through-wall cladding defect somewhere in the assembly. Ultrasonic testing looks for water in individual fuel rods as an indicator of a cladding defect. However, none of these poolside methods provide qualitative data related to cladding properties such as effects of hydriding and ductility.

Current fuel assembly designs provide for the relatively easy removal of fuel rods from a fuel assembly. The upper tie plates are designed to be removed; this provides access to the individual fuel rods. Once a fuel rod is removed, a dummy rod is put back into its place to maintain the same volume of water potentially available for neutron moderation (water moderator displacement). In general, a pulled fuel rod is not put back into the reactor.

The fuel vendors are able to perform detailed visual inspections of fuel assemblies and make measurements of the following fuel performance parameters: 
- Fuel rod diameter and profilometry - measured using linear variable differential transformers (LVDTs). Measurements are made at locations between grid spacers when the rods are in the fuel assemblies. Measurements can be made along the full-length of an individual rod removed from the fuel assembly.

- Fuel rod and spacer oxide thickness - measured with an eddy current-based system.

- Fuel rod length (determined indirectly from photographic measurements using scaling factors from known dimensions) and plenum length (based on eddy current measurements and a dial indicator).

- Gamma scanning - using a germanium detector and underwater collimator to determine axial burnup.

- Fission gas release (unique to Framatome) - determined by measuring the Kr-85 activity in the plenum.

- Eddy current inspection - examines cladding defects and cladding wall thinning of individual fuel rods.

- Crud sampling (samples are taken by controlled scraping and sent off site for analysis).

- Fuel rod bow and rod-to-rod spacing_-determined by measuring the gap between fuel rods.

- Assembly bow and twist values - based on the bow and twist of guide tubes in the assembly.

- Guide tube and assembly length, spacer envelope dimensions, and internal water channel dimensions - determined by comparing with known length or using LVDTs.

- Fuel rod withdrawal force — using a load cell.

- Spacer spring relaxation — using a load cell and a plug gauge.

- Hold-down spring force and height — using a load cell and an LVDT.

- Rod control cluster assemblies (RCCA) wear.

Individual rods can be examined visually using a station or a periscope and the data recorded. Visual examinations allow additional inspection of cladding defects detected by eddy current testing.

Most of the measurements are nonintrusive to the fuel and may be taken during a scheduled reactor outage with minimal disruption of the preplanned core loading scheme. Many of the measurements can be obtained without requiring disassembly of the fuel assembly. More extensive examinations may be performed on discharged fuel during normal cycle operations. The more extensive examinations usually involve removal of a fuel rod from an assembly. Generally, removed rods are not reinserted into an assembly that is to be reinserted into the reactor core. These exams would allow significant nondestructive characterization of the highburnup spent fuel prior to dry storage. Destructive examination of sibling rods retained in wet storage and rods experiencing dry storage could be performed at the end of the demonstration. 


\subsubsection{National Laboratories}

Selected DOE national laboratories (ANL-E, ANL-W, INEEL, ORNL, PNNL, and SRS) were contacted and asked to respond to a survey about their interest in serving as a demonstration site and provide fuel examination services for the potential demonstration project. Written responses to the survey questionnaire were provided by ANL-W, INEEL, ORNL, PNNL, and SRS/SRTC. The laboratories were asked about available facilities, expertise, and experience in receiving and examining spent nuclear fuel.

Two principal sets of fuel examinations are envisioned. The objective of these examinations would be to identify changes that could be attributed to the dry storage period and that would affect the performance of the fuel. Examples of areas of potential concern include 1) creep (because of the pressure differential between the cask cover gas and rod internal gas pressure), which could hamper the removal of the fuel from the fuel assemblies, and 2) loss of fracture toughness or ductility, which could affect the survivability of the fuel during impacts from handling or accidents. Configuration control of the fuel rod and assembly geometry in the casks is a primary concern because of its impact on criticality analyses.

The first set of examinations is expected to be a poolside examination of the selected spent fuel (see Section 3.2.1). This examination would include some visual analyses, some dimensional analyses, and eddy current (for oxide thickness). Another potential examination is measurement of ${ }^{85} \mathrm{Kr}$ activity in the rod plenums. ${ }^{85} \mathrm{Kr}$ activity can be correlated to rod-average fission gas release and, thus, can provide an estimate of rod internal gas pressure. It is anticipated that four to six sibling fuel rods would be left in the spent fuel pool during the dry storage demonstration project to serve as a "control" during the post-demonstration examination of the spent fuel.

The second principal set of fuel examinations would follow the dry storage demonstration period. These examinations would include both nondestructive and destructive examinations. A selected number of rods, including at least one that had been left in the spent fuel pool, would be nondestructively examined. These examinations would include visual, profilometry (primarily for rod diameter changes during dry storage), axial gamma scanning (for radioisotope redistribution during dry storage), and rod puncture and gas analysis (to confirm rod internal gas pressure during dry storage). The destructive examinations would be performed on a smaller number of rods and would focus on mechanical property changes of the cladding, i.e., yield strength, ultimate strength, ductility, fracture toughness, creep, etc. Selected cross sections would be taken from the rods selected for examination. Other potential examinations would be analysis of hydrogen concentration and distribution in the cladding, and etching for evidence of hydride reorientation.

The responses (in the appendix) are summarized in Table 3-3 and briefly discussed in the following subsections. It is apparent that ANL-W is currently most capable of handling the fulllength fuel rods and performing many of the desired post-test fuel examinations. However, a significant concern/issue with ANL-W is their ability to receive and then dispose of the commercial spent fuel needed for this demonstration project. The other national laboratories apparently have fewer issues in dealing with commercial spent fuel but would need to put additional capabilities into place for performing examinations on full-length fuel rods. 
Table 3-3

Summary of National Laboratory Responses about Performing the Fuel Examinations

\begin{tabular}{|c|c|c|c|c|c|}
\hline Question & ANL-W & INEEL & ORNL & PNNL & SRTC \\
\hline Contact & $\begin{array}{l}\text { David S. Duncan } \\
\text { 208-533-7847 } \\
\text { david.duncan@anl.gov }\end{array}$ & $\begin{array}{l}\text { Thomas J. Hill } \\
\text { 208-526-1711 } \\
\text { tjh@inel.gov }\end{array}$ & $\begin{array}{l}\text { Donald Spellman } \\
\text { 865-574-7891 } \\
\text { spellmandj@ornl.gov }\end{array}$ & $\begin{array}{l}\text { John Abrefah } \\
\text { 509-373-0927 } \\
\text { john.abrefah@pnl.gov }\end{array}$ & $\begin{array}{l}\text { Mark Dupont } \\
\text { 803-725-0954 } \\
\text { mark.dupont@srs.gov } \\
\end{array}$ \\
\hline $\begin{array}{l}\text { Interested in providing } \\
\text { fuel examination services }\end{array}$ & - Yes & $\begin{array}{l}\text { - Yes, would be done in } \\
\text { conjunction with ANL-W }\end{array}$ & $\begin{array}{l}\text { - Yes, fits well with MOX } \\
\text { fuel handling and } \\
\text { examination work }\end{array}$ & $\begin{array}{l}\text { Yes; have experience } \\
\text { examining fuels and } \\
\text { other irradiated } \\
\text { materials }\end{array}$ & - Yes \\
\hline Proposed facility & $\begin{array}{l}\text { - Hot Fuels Examination } \\
\text { Facility (HFEF) }\end{array}$ & - See ANL-W response & $\begin{array}{l}\text { - Irradiated Fuels } \\
\text { Examination } \\
\text { Laboratory (IFEL) }\end{array}$ & $\begin{array}{l}\text { - Radiochemical } \\
\text { Processing Laboratory } \\
\text { (RPL) }\end{array}$ & \\
\hline $\begin{array}{l}\text { General facilities, } \\
\text { capabilities }\end{array}$ & $\begin{array}{l}\text { - Able to receive NAC- } \\
\text { LWT shipping cask } \\
\text { - Full-length } \\
\text { nondestructive } \\
\text { examinations: neutron } \\
\text { radiography, visual, } \\
\text { gamma scanning, } \\
\text { contact profilometry, } \\
\text { rod puncture and gas } \\
\text { analysis } \\
\text { - Sectioning, optical } \\
\text { microscopy }\end{array}$ & - See ANL-W response & $\begin{array}{l}\text { - Visual, metrology, } \\
\text { gamma scan, rod } \\
\text { puncture and gas } \\
\text { analysis, } \\
\text { ceramography, } \\
\text { SEM/EPMA, } \\
\text { radiochemistry } \\
\text { - Profilometry and axial. } \\
\text { - Eddy current and TEM. }\end{array}$ & $\begin{array}{l}\text { - High Level Radiochem- } \\
\text { ical Facility (HLRF) hot } \\
\text { cells in RPL not large } \\
\text { enough to handle and } \\
\text { examine full-length } \\
\text { rods, but a conceptual } \\
\text { airlock system that } \\
\text { accommodates full- } \\
\text { length rods, including } \\
\text { nondestructive exam- } \\
\text { ination, has been } \\
\text { designed and prepared } \\
\text { - Capability exists for } \\
\text { optical microscopy, } \\
\text { SEM, TEM }\end{array}$ & $\begin{array}{l}\text { - Shielded cells with } \\
\text { manipulators for } \\
\text { metallurgical } \\
\text { characterization } \\
\text { - Visual, profilometry, } \\
\text { axial gamma scanning, } \\
\text { rod puncture and gas } \\
\text { analysis, metallurgical } \\
\text { characterization }\end{array}$ \\
\hline $\begin{array}{l}\text { Able to remove individual } \\
\text { rods from assemblies }\end{array}$ & - Yes & $\begin{array}{l}\text { - Yes, demonstrated as } \\
\text { part of OCRWM's dry } \\
\text { rod consolidation } \\
\text { program }\end{array}$ & $\begin{array}{l}\text { - Can be done at HFIR; } \\
\text { but not proposing to do } \\
\text { so } \\
\text { - Proposing using rod } \\
\text { packets and a dry } \\
\text { transfer system }\end{array}$ & $\begin{array}{l}\text { - RPL airlock extension } \\
\text { would include capability } \\
\text { to remove individual } \\
\text { rods from a fuel } \\
\text { assembly }\end{array}$ & $\begin{array}{l}\text { - Extensive capabilities } \\
\text { and experience in } \\
\text { remote tooling and } \\
\text { handling and could } \\
\text { develop necessary } \\
\text { capability }\end{array}$ \\
\hline
\end{tabular}


Table 3-3

Continued

\begin{tabular}{|c|c|c|c|c|c|}
\hline Question & ANL-W & INEEL & ORNL & PNNL & SRTC \\
\hline $\begin{array}{l}\text { Able to conduct } \\
\text { mechanical testing on } \\
\text { irradiated cladding }\end{array}$ & $\begin{array}{l}\text { - Would fabricate speci- } \\
\text { mens and send to ANL- } \\
\text { E Alpha-Gamma Hot } \\
\text { Cell Facility (AGHCF) } \\
\text { for mechanical testing. } \\
\text { AGHCF has capability } \\
\text { for axial and ring tensile } \\
\text { testing, elevated tem- } \\
\text { perature and pressure } \\
\text { creep testing, fracture } \\
\text { toughness, hardness }\end{array}$ & - See ANL-W response & $\begin{array}{l}\text { - Creep measurements } \\
\text { and fracture toughness } \\
\text { in two facilities (CCCTF } \\
\text { facility and RMAL } \\
\text { facility); } \\
\text { - New method of } \\
\text { cladding stress/strain } \\
\text { measurements will be } \\
\text { used on MOX fuel in } \\
2003\end{array}$ & $\begin{array}{l}\text { - Mini-cell in } 323 \text { Building } \\
\text { for creep and tensile } \\
\text { testing of irradiated } \\
\text { cladding; could be } \\
\text { duplicated in RPL hot } \\
\text { cells if necessary }\end{array}$ & $\begin{array}{l}\text { - Capabilities for } \\
\text { mechanical testing on } \\
\text { nuclear materials; } \\
\text { would need to be } \\
\text { adapted for irradiated } \\
\text { cladding }\end{array}$ \\
\hline $\begin{array}{l}\text { Capabilities for receiving } \\
\text { spent fuel, examining full- } \\
\text { length rods/ assemblies }\end{array}$ & $\begin{array}{l}\text { - HFEF can receive } \\
\text { commercial shipping } \\
\text { casks such as the } \\
\text { NAC-LWT } \\
\text { - Able to handle and } \\
\text { examine full-length } \\
\text { rods, remove rods from } \\
\text { assemblies }\end{array}$ & $\begin{array}{l}\text { - Use TAN Hot Shop to } \\
\text { transload, disassemble, } \\
\text { and inspect in adjacent } \\
\text { hot cells } \\
\text { - Have demonstrated } \\
\text { ability to transfer full- } \\
\text { length rods to ANL-W } \\
\text { for examination }\end{array}$ & $\begin{array}{l}\text { - IFEL can only handle } \\
\text { rods up to } 5 \mathrm{ft} \\
\text { - Full-length bundles } \\
\text { could be handled in } \\
\text { REDC at HFIR } \\
\text { - Handling full bundles } \\
\text { not proposed because } \\
\text { of expense and waste } \\
\text { considerations; instead } \\
\text { propose packets of } \\
\text { selected rods } \\
\text { - Required upgrades for } \\
\text { IFEL for full-length } \\
\text { rods: upgrade internal } \\
\text { building crane and } \\
\text { design/ build mating } \\
\text { flange from shipping } \\
\text { cask to the hot cell; } \\
\text { complete by June } 2004\end{array}$ & $\begin{array}{l}\text { - Airlock extension would } \\
\text { be necessary to handle, } \\
\text { examine, and section } \\
\text { full-length rods; a } \\
\text { design exists for this } \\
\text { extension and } \\
\text { supporting NDE } \\
\text { equipment }\end{array}$ & $\begin{array}{l}\text { - Cannot currently accept } \\
\text { full-length fuel } \\
\text { assemblies; but such } \\
\text { capabilities are being } \\
\text { considered to support } \\
\text { other missions }\end{array}$ \\
\hline
\end{tabular}




\subsubsection{ANL-W and INEEL}

The most capable examination facility at INEEL is ANL-W's HFEF, as evidenced by INEEL proposing to work with ANL-W to conduct the fuel rod examinations if selected as the demonstration site. The HFEF is capable of receiving commercial shipping casks and performing examinations on full-length fuel rods. Available examinations include visual, metrology (diameter, bow, length), axial gamma scanning, neutron radiography, SEM, and rod puncture and gas analysis. Destructive examination capabilities include microscopy using a variety of optical and electronic instruments, hardness testing, preparing samples for mechanical testing by ANL-E, and chemical analyses for density, burnup, and fission and activation products. As noted in Section 3.1.2, the biggest issue for both ANL-W and INEEL are the restrictions on bringing spent fuel into Idaho, performing research, and then dispositioning the spent fuel in less than five years.

\subsubsection{ORNL}

ORNL proposed using the IFEL for fuel examinations. This facility is not capable of handling and examining full-length fuel rods. Upgrades that would allow working with full-length rods will be completed in June 2004 and include the internal building crane and work necessary to mate shipping casks to the hot cell. Current capabilities include visual, metrology, axial gamma scanning, rod puncture and gas analysis, optical microscopy, scanning electron microscopy and electron probe microanalysis, gas chromotography, and radiochemistry. A new process for measuring cladding stress/strain has been developed for the MOX PIE program and will be available for this project.

\subsubsection{PNNL}

PNNL proposed using their RPL for performing the fuel examinations. This facility is not currently capable of handling and examining full-length fuel rods. A conceptual design exists for adding an airlock to the largest hot cell in RPL. This shielded airlock would be sufficiently large to handle full-length rods, and the nondestructive examination equipment (visual, metrology, axial gamma scanning, rod puncture and gas analysis) would be installed in the airlock. Costs for installation of this airlock system are not included in the PNNL proposal. Subsequent destructive examinations (e.g., optical microscopy, scanning electron microscopy, etc.) would be conducted in other shielded facilities within RPL. Existing capabilities in the RPL include high-resolution optical microscopy, scanning electron microscopy for irradiated samples, transmission electron microscopy on irradiated samples, and radiochemistry. Creep and tensile testing of irradiated cladding can be conducted in a mini-cell in another building. As with many other facilities in the DOE complex, accelerated cleanup schedules could affect the availability of the facility. 


\subsubsection{SRS}

SRS facilities include shielded cells and facilities for nondestructive and destructive examinations of the spent fuel rods. Capabilities include visual, profilometry, axial gamma scanning, and rod puncture and gas analysis. Optical microscopy capabilities are also available. Mechanical testing capabilities are available for nuclear materials and could be adapted to irradiated cladding. However, current facilities cannot accommodate full-length fuel assemblies and rods; modifications to accommodate full-length rods are being contemplated.

\subsubsection{ANL-E}

Although they did not respond to the survey, ANL-E has an installed capability to perform mechanical testing on irradiated cladding (see Section 2). The testing includes stress-strain mechanical testing and creep testing. This capability was installed for the NRC to obtain data on high-burnup cladding; the testing protocols have been developed in conjunction with the nuclear industry. Samples would have to be shipped from ANL-W as is the current practice.

\subsubsection{Common Laboratory Concerns}

Several concerns, issues, or potential problems were raised by the national laboratories when considering the post-demonstration fuel examinations. These points are summarized and discussed in the following.

- Ability to handle full-length fuel assemblies and/or rods. Only the HFEF at ANL-W is currently capable of handling and examining full-length assemblies and rods. Two of the other facilities (RPL at PNNL, IFEL at ORNL) either have plans in place for a future capability to handle full-length rods, or have a conceptual design of how to handle full-length rods. ORNL has an approved project to upgrade facilities that will be completed in June 2004. Full capabilities will exist at ORNL at that time. SRTC stated that capabilities to handle full-length assemblies and rods are being considered to support other missions. Installing a capability to handle and examine full-length assemblies/rods will add to the examination expense.

- Examination Capabilities. Depending on the suite of examinations that is finally chosen, not all examination capabilities may be available at one laboratory. For example, scanning electron microscopy capabilities exist only at PNNL, ORNL, and ANL-W. In addition, another national laboratory may be best for performing a specific examination; for instance, ANL-E may be best equipped to perform mechanical testing of irradiated cladding. Therefore, it may be necessary to use more than one laboratory to achieve all the desired examinations.

\subsection{Dry Storage Cask Options}

Four general cask designs have been approved for use in licensed ISFSIs: vertical metal storage casks, vertical concrete-shielded metal storage casks, horizontal metal canisters housed in 
concrete modules, and concrete storage vaults. Falling within these four general designs are a total of 19 dry cask storage system designs made by seven different vendors. All have been approved or certified by the NRC over the last 20 years (Gruss 2002).

Four vendors are currently providing spent fuel storage systems to ISFSIs in the United States. They are General Nuclear Systems, Inc. (GNSI); Holtec International; NAC International; and Transnuclear, Inc. Representatives from each of these vendors were contacted with respect to their systems that might be considered for use in the demonstration project. Initially, only systems with bolted lids were considered because of the relative ease of being able to remove a lid and extract fuel for examination at the conclusion of the storage demonstration. However, as most of the systems now being used and expected to be used in the foreseeable future are canister based, the study was expanded to include canister systems as well. Because the canister will need to be opened at the end of the demonstration to allow the high-burnup spent fuel to be removed for further inspection and characterization, the canister is assumed to be expendable in the demonstration program. After the lid has been removed from the canister, the fuel will need to be transferred to a new canister or to a spent fuel pool.

There are 24 dry storage ISFSIs in the United States, as shown in Figure 3-1 and listed in Table 3-4. The table shows that each storage site is associated with a specific dry storage technology, except for the Surry site. If the demonstration is conducted at a utility site, the storage system used in the demonstration will need to match that being used or planned at that site to minimize the impact of the demonstration on normal plant operations. If the demonstration is performed at a national laboratory, the storage system selection may not be as limited; however, considerations will need to include available cask handling capabilities at each laboratory and/or the cost of a modification to accommodate the project. Typically, a loaded dry storage cask, transfer cask, or transportation cask will weigh on the order of 100 tons and be less than 100 inches in diameter. A vertical concrete storage module containing a canister loaded with spent fuel will weigh in excess of 125 tons and be over 130 inches in diameter. This size and weight exceed existing crane and cask transporter capacities at the national laboratories.

It is anticipated that a number of licensing issues will also need to be addressed in the storage system selection process. None of the licensed systems provide for gas sampling of the backfill gas in the cask or canister, nor do they provide for the monitoring of basket or fuel temperatures within the cask or canister. If the fuel temperature limit $\left(400^{\circ} \mathrm{C}\right)$ and cooling times are to be challenged, license amendments or exemptions will be needed to support the demonstration. 
Table 3-4

U.S. Generating Companies with Onsite Dry Storage Commitments (NEI 2002)

\begin{tabular}{|c|c|c|c|c|}
\hline Owner/Operator & Reactor & $\begin{array}{l}\text { Dry Storage } \\
\text { Technology }\end{array}$ & $\begin{array}{l}\text { Licensing } \\
\text { Method }^{(\mathrm{a}}\end{array}$ & $\begin{array}{l}\text { Facility } \\
\text { Date }^{(b)}\end{array}$ \\
\hline Dominion Generation & Surry $1 \& 2$ & Metal Casks ${ }^{(\mathrm{c})}$ & Site Specific & 1986 \\
\hline Progress Energy (CP\&L) & H.B. Robinson & NUHOMS-07P & Site Specific & 1986 \\
\hline Duke Energy & Oconee $1,2, \& 3$ & NUHOMS-24P & Site Specific & 1990 \\
\hline $\begin{array}{l}\text { Public Service Company of } \\
\text { Colorado }\end{array}$ & Fort St. Vrain & Foster Wheeler MVDS & Site Specific & 1991 \\
\hline Constellation Nuclear & Calvert Cliffs $1 \& 2$ & NUHOMS-24P & Site Specific & 1992 \\
\hline Consumers Energy & Palisades & VSC-24, NUHOMS 32PT & General License & 1993 \\
\hline $\begin{array}{l}\text { Nuclear Management Company } \\
\text { (Xcel Energy) }\end{array}$ & Prairie Island $1 \& 2$ & $\mathrm{TN}-40$ & Site Specific & 1993 \\
\hline $\begin{array}{l}\text { Nuclear Management Company } \\
\text { (WEPCO) }\end{array}$ & Point Beach $1 \& 2$ & VSC-24, NUHOMS 32PT & General License & 1995 \\
\hline First Energy & Davis Besse & NUHOMS-24P & General License & 1995 \\
\hline Entergy Operations & $\begin{array}{l}\text { Arkansas Nuclear One } 1 \& \\
2\end{array}$ & VSC-24 & General License & 1996 \\
\hline Dominion Generation & North Anna $1 \& 2$ & TN-32 & Site Specific & 1998 \\
\hline PP\&L & Susquehanna $1 \& 2$ & NUHOMS-52B & General License & 1999 \\
\hline Exelon Generation & Dresden 1 & Holtec HI-STAR & General License & 2000 \\
\hline Exelon Generation & Peach Bottom 2 \& 3 & $\mathrm{TN}-68$ & General License & 2000 \\
\hline $\begin{array}{l}\text { Southern Nuclear Operating } \\
\text { Company }\end{array}$ & Hatch $1 \& 2$ & Holtec HI-STORM & General License & 2000 \\
\hline Duke Energy & McGuire $1 \& 2$ & TN-32/ NAC UMS & General License & 2001 \\
\hline Portland General Electric & Trojan & Holtec & Site Specific & 2002 \\
\hline $\begin{array}{l}\text { Sacramento Municipal Utility } \\
\text { District }\end{array}$ & Rancho Seco & NUHOMS-MP187 & Site Specific & 2001 \\
\hline Amergen & Oyster Creek & NUHOMS - 61BT & General License & 2002 \\
\hline Yankee Atomic Electric Company & Yankee Rowe & NAC MPC & Site Specific & 2002 \\
\hline Energy Northwest & WNP2 & Holtec HI-STORM & General License & 2002 \\
\hline
\end{tabular}


Table 3-4

(continued)

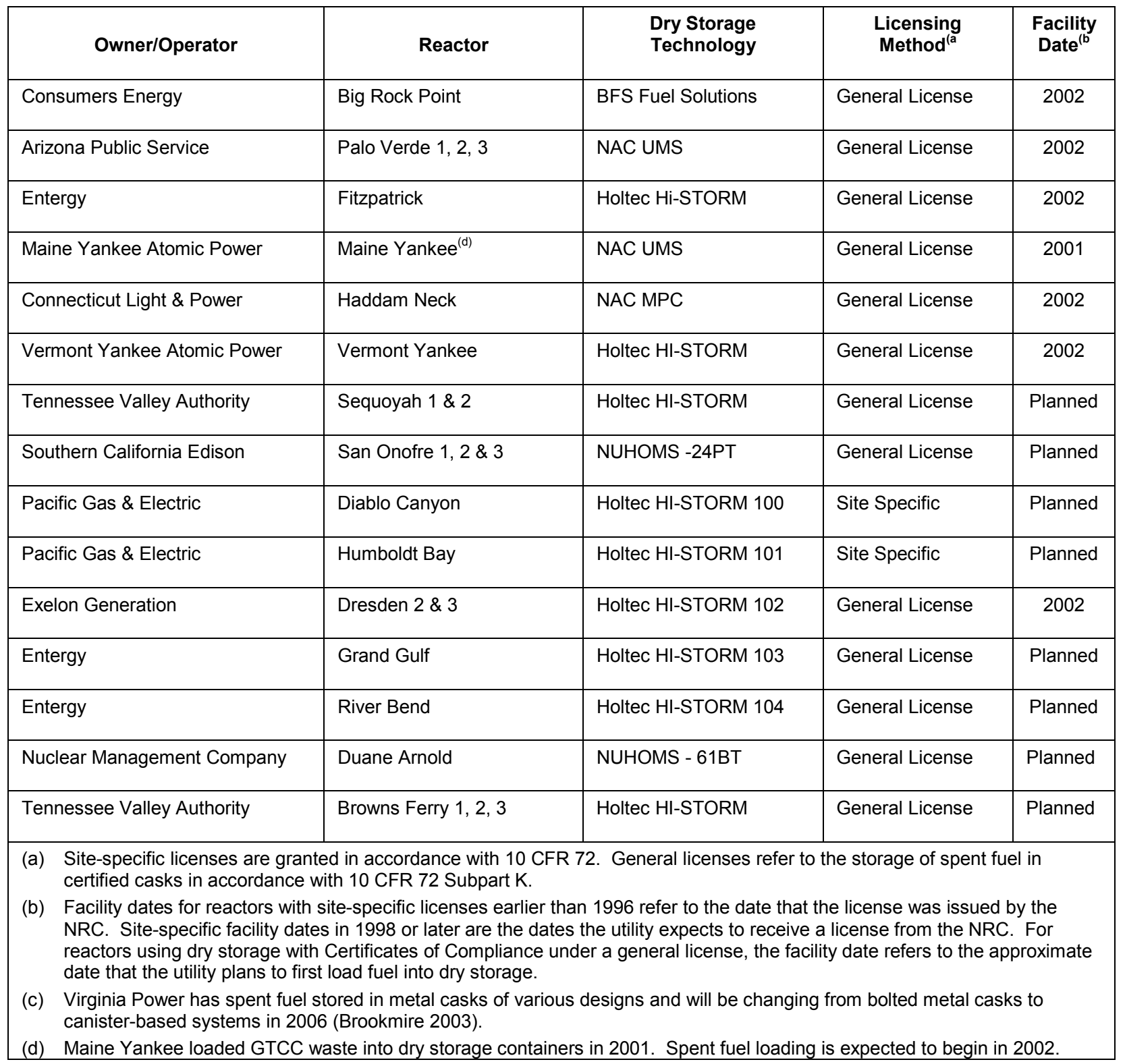

\subsubsection{Cask Vendors}

The four cask vendors offering dry storage systems licensed by the NRC for commercial spent nuclear fuel are General Nuclear Systems, Inc.; Holtec International; NAC International; and Transnuclear, Inc. GNSI's presence has been limited to the Surry Reactor site in the United States. BNFL Fuel Solutions Corporation also holds certificates of compliance for dry storage systems, but is no longer providing hardware. The other three cask vendors (NAC, Holtec, and Transnuclear) were contacted for information on their systems. They were asked if they would be interested in participating in a demonstration of dry storage of high-burnup spent fuel and under what conditions. A summary of their responses is found in Table 3-5. Several of the 
Table 3-5

Summary of Information Received from Cask Vendors

\begin{tabular}{|c|c|c|c|c|}
\hline Vendors & GNSI/GNB & Holtec Intl. & NAC Intl & Transnuclear \\
\hline Contact & Alfons Luehrmann & Kris Singh & Jim Ballowe, Charlie Pennington & Bill Gallo \\
\hline Interest & \multicolumn{4}{|c|}{ Common interest of establishing or expanding future market shares } \\
\hline $\begin{array}{l}\text { High- } \\
\text { Burnup } \\
\text { Systems } \\
\text { Available }\end{array}$ & $\begin{array}{l}\text { CONSTOR V, Metal cask, } 32 \\
\text { PWR/69 BWR, } 5 \% \text { enrichment, } \\
60 \text { GWd/MTU, } 113 \text { to } 125 \\
\text { metric tonnes loaded, heavy } \\
\text { concrete and steel, bolted lid. } \\
\text { CASTOR V/21A, Metal cask, } \\
24 \text { PWR, } 5 \% \text { enrichment, } 60 \\
\text { GWd/MTU, } 106 \text { to } 117 \text { metric } \\
\text { tonnes loaded, ductile cast iron } \\
\text { cask body, bolted lid. }\end{array}$ & $\begin{array}{l}\text { HI-STORM (Storage) and HI- } \\
\text { STAR (Storage and Transport), } \\
\text { canister-based systems, } \\
68.2 \mathrm{GWd} \text { /MTU for PWR and } \\
59.9 \mathrm{GWd} \text { /MTU for BWR, } \\
\text { regionalized fuel loading to limit } \\
\text { dose. }\end{array}$ & $\begin{array}{l}\text { NAC S/T and NAC C28 S/T dual- } \\
\text { purpose metal casks. } \\
\text { NACogUMS and MPC canister } \\
\text { based system. } \\
\text { NI } 1-2 \text { shipping cask that could be } \\
\text { used for the demonstration. } \\
\text { Metal legal weight truck cask } \\
\text { with liquid neutron shield, } 1 \\
\text { PWR/2 BWR, } 23 \text { tons, } \\
\text { Fuel clad temperatures to } \\
543^{\circ} \mathrm{C}\left(1010^{\circ} \mathrm{F}\right) \text {. } \\
\text { NAC LWT shipping cask is able to } \\
\text { ship up to } 25 \text { fuel rods with } \\
\text { burnup to } 80 \mathrm{GWd} / \mathrm{MTU} \text {. }\end{array}$ & $\begin{array}{l}\text { TN-24 (PWR), TN-32 (PWR), and } \\
\text { TN-68 (BWR) metal casks. } \\
\text { NUHOMS canister-based storage } \\
\text { and dual-purpose system. } \\
\text { NUHOMS 24PHB, } 24 \text { PWR, } \\
55 \text { GWd/MTU, 7.3-year cooled, } \\
4.5 \% \text { enrichment. } \\
\text { NUHOMS 24PTH, } 24 \text { PWR, } \\
62 \text { GWd/MTU, 5-year cooled, } \\
5 \% \text { enrichment. } \\
\text { NUHOMS 32PTH, } 32 \text { PWR, } \\
62 \text { GWd/MTU, 7-year cooled, } \\
5 \% \text { enrichment. } \\
\text { TN 32-H, dual-purpose metal, } \\
32 \text { PWR, 60 GWd/MTU, 7-year } \\
\text { cooled, 5\% enrichment (Shakir } \\
2003 \text { ). } \\
\text { TN-68, } 50 \text { GWd/MTU, 7-year } \\
\text { cooled, 4.25\% enrichment } \\
\text { (Hunter 2003). }\end{array}$ \\
\hline
\end{tabular}


Table 3-5

(continued)

\begin{tabular}{|c|c|c|c|c|}
\hline Vendors & GNSI/GNB & Holtec Intl. & NAC Intl & Transnuclear \\
\hline $\begin{array}{l}\text { Licensing } \\
\text { Status: } \\
\text { Current }\end{array}$ & $\begin{array}{l}\text { GNS V/21 and GNS X/33 storage- } \\
\text { only licenses for lower burnup } \\
<45 \mathrm{GWd} / \mathrm{MTU} \text {. }\end{array}$ & Licensed for storage. & Licensed systems. & $\begin{array}{l}\text { TN cask systems are currently } \\
\text { licensed for }<45 \mathrm{GWd} / \mathrm{MTU} \text {. } \\
\text { Some NUHOMS systems are } \\
\text { licensed for burnups } \\
>45 \mathrm{GW} \text { d/MTU. }\end{array}$ \\
\hline $\begin{array}{l}\text { Licensing } \\
\text { Status: In } \\
\text { Progress }\end{array}$ & CONSTOR V. & Seeking license for transportation. & & $\begin{array}{l}\text { NUHOMS 24PHB, NUHOMS } \\
24 \mathrm{PTH}, \mathrm{NUHOMS} 32 \mathrm{PTH}, \mathrm{TN} 32- \\
\mathrm{H} \text { and TN-68. }\end{array}$ \\
\hline Costs & & & & $\begin{array}{l}\sim \$ 2 \mathrm{M} \text { for TN-68 BWR storage } \\
\text { cask. } \\
\sim \$ 1 \mathrm{M} \text { for NUHOMS canister/ } \\
\text { storage module. } \\
\sim \$ 3 \mathrm{M} \text { Transportation } \\
\text { overpack/impact limiters. }\end{array}$ \\
\hline
\end{tabular}


canister-based dry storage systems are licensed for storing spent fuel with burnup at or above $60 \mathrm{GWd} / \mathrm{MTU}$. Dual-purpose systems are not currently licensed or are only licensed for transportation of spent fuel with burnup no greater than $45 \mathrm{GWd} / \mathrm{MWU}$.

\subsubsection{Pre- and Post-Test Examination of Storage System}

Pre-storage documentation of the cask is required to serve as a baseline for any post-test cask examinations that may be desired. Based on the examinations that were performed on the CASTOR V/21 cask after a 14-year storage period (Bare and Torgerson 2001), the post-test cask examinations may include the following:

- Examination of the concrete storage pad upon which the dry storage system rested for any degradation of the concrete pad.

- Inspection of the interior of the cask/canister for any degradation.

- Inspection of the closure welds, bolts, and/or seals for any degradation.

- Inspection of the interior of the canister/basket for corrosion, presence of crud spalled from fuel assemblies, gouging of the basket caused by fuel loading/unloading, and basket weld degradation.

- Characterization of the neutron shield material.

The basket/canister should be well characterized prior to loading to provide a baseline for comparison with the results from the post-test examinations. The pretest characterization of the cask should be easy to perform since radiation is not present. The post-test examinations should only have to contend with contamination from crud, etc., but not with any measurable activation of the structural materials from the neutron flux coming off the spent fuel. 


\section{4 \\ DEMONSTRATION}

Multiple options exist for a confirmatory demonstration program. Provided here are three general "recommended" options for a confirmatory dry storage program. For each of the options, it is assumed that the chosen spent fuel will be of the highest-possible burnup and be from high-duty cycles (i.e., bounding-type spent fuel), as discussed in Section 2.5.

Before discussing the recommended options, the following list presents "desired" requirements/attributes for a confirmatory demonstration program.

- Because this is planned as a confirmatory program, work should be done as close as possible to, or even beyond, the upper bound of allowable conditions. Therefore, some of the spent fuel used in the demonstration should be characterized by:

- burnup as high as possible

- different types of claddings (Zircaloys; Zirlo ${ }^{\text {TM}}$; M5)

- high duty cycles (increased oxidation and hydrogen pickup, larger internal rod pressure)

- With regard to the storage conditions:

- peak cladding temperatures should be close to, or possibly exceed, $400^{\circ} \mathrm{C}$ (present licensing limit from ISG-11, Rev. 2) during the demonstration

- "short" cooling times may be desirable (creep and hydride dissolution and reprecipitation phenomena), but shielding may become a limiting consideration (requiring hot, short-cooled fuel at the center of the cask/canister, and long-cooled fuel at the periphery)

- demonstration program likely to run for a minimum of five years to capture the high temperature end of long-term dry storage.

- Monitoring activities:

- internal monitoring of fuel temperatures

- periodic sampling of cask fill gas to determine if any rods are failing.

- Characterization and examinations of the spent fuel:

- fresh fuel design characteristics

- power histories (fuel burnup; cladding fluence)

- pre-storage characterization for baseline 
- identification of pool-stored sibling rods to be examined along with dry-stored rods (evaluation of storage effects)

- properties relevant to storage (cladding integrity, retrievability) and transportation (structural integrity or potential for reconfiguration):

- assembly geometry

- dimensional changes (e.g., creep)

- mechanical properties (yield and ultimate strengths, ductility, fracture toughness)

- gas pressure/fission gas release (creep, degradation and source term characterization if rod fails)

- Storage system:

- pre-test baseline

- periodic radiation monitoring

- post-test examinations (mostly visual).

\subsection{Augmentation of an Existing Utility Program}

Several utilities, in cooperation with fuel vendors, conduct programs to characterize in-reactor fuel performance. These programs typically use lead test assemblies (LTAs) to achieve burnups higher than those presently licensed for commercial spent fuel. After these experimental LTAs have achieved their burnup objectives, the potential exists for rods to be extracted from these assemblies and shipped to a hot cell after they have cooled sufficiently in the spent fuel pool. The opportunity exists to augment testing of the spent fuel sent to a hot cell to support the data needs driven by dry storage and transportation. While the option does not provide results for fuel that has been in dry storage, it does allow development of a database that supports the condition of the spent fuel at the time it goes into spent fuel storage. It would also allow additional testing on mechanical and fracture properties of the spent fuel. Under this option, the utility would willingly expand the scope of the post-test examinations provided it would not significantly affect schedule and cost. Because some of these programs are already in progress, DOE, EPRI, and the NRC would have less programmatic flexibility for modifying them, especially with regard to the initial characteristics of the fuel (fuel cycle duty, cladding, etc.); but they represent opportunities for cost-effectively augmenting the amount of testing to be done.

\subsection{Demonstration at an Existing Utility ISFSI Site}

This option is based on collaborating with a utility that has an existing ISFSI. Selected spent fuel would be examined in the spent fuel pool and then placed into dry storage in a modified dry cask storage system. The dry storage period would take place at the utility site, then selected fuel rods would be shipped to a national laboratory for post-test examination. The remaining rods would be placed into a standard licensed storage system until they are shipped to the geologic repository. For this option, the following actions would be performed, with the costs of the activities above normal plant and ISFSI operations being borne by the program: 
- A modified storage system would be obtained for use at the utility's ISFSI site. This storage system would be identical to the ISFSI storage system except for modifications required to allow measuring fuel temperatures inside the cask or canister, sampling of the cover/backfill gas, and extraction of a spent fuel $\operatorname{rod}(\mathrm{s})$ from the canister.

- The utility would acquire the modified storage system.

- The cask vendor would be responsible for the license amendment for the modified cask; the program and utility would assist in this activity.

- The utility would be responsible if a license amendment is necessary for the site to conduct the confirmatory program (not expected to be necessary).

- The utility and/or fuel vendor would examine the selected fuel in the spent fuel pool prior to dry storage. A sibling rod(s) to those placed in dry storage will be kept in the spent fuel pool to provide a baseline comparison at the end of the demonstration period.

- Fuel temperatures and cask fill gas composition would be monitored during the storage period (minimum of five years).

- At the conclusion of the demonstration period, selected rods from the dry storage system, and the sibling rod(s) kept in the spent fuel pool, would be sent to a national laboratory for destructive examination.

- The confirmatory program would arrange shipping of the spent fuel.

- The confirmatory program would examine the storage system for any potential storage impacts.

- The utility would be responsible for returning the balance of the spent fuel to dry storage.

- The national laboratory would perform examinations of the selected fuel to identify changes that may have occurred during the dry storage demonstration program. Of particular interest would be dimensional changes during dry storage and characterizing the mechanical properties of the cladding after irradiation and after dry storage. At the conclusion of the examination, the national laboratory would dispose of the spent fuel.

Using an existing ISFSI at a utility site has the advantage of minimizing the amount of fuel that has to be shipped to a laboratory for analysis. It allows the use of commercial casks/canisters using approved procedures and provides greater control by the utility. It is confined to a single fuel type (PWR or BWR) and storage canister type but may include more than one fuel burnup and cladding type.

\subsection{Demonstration at a National Laboratory}

This option is based on acquiring selected spent fuel and then performing both the confirmatory demonstration and the fuel examinations at a national laboratory. The activities are similar to the demonstration project that was previously conducted at INEEL (Kimball and Billone 2003; McKinnon and Deloach 1993). For this option, the following actions would be performed: 
- A modified storage system would be obtained for use at the national laboratory. The storage system would need to be modified to allow measuring fuel temperatures inside the cask or canister, gas sampling of the cover/backfill gas, and extraction of a spent fuel rod(s) from the canister. There are two principal options for the selected system:

- a full-size system that would require a large number of fuel assemblies to fill

- a transportation cask or simulated storage system that would hold only one or few selected fuel assemblies.

- The confirmatory program would be responsible for the procurement of the modified storage system.

- The modifications would need to be evaluated including the requirement for an NRC license amendment because the demonstration would be done at a DOE site.

- The cask vendor would be responsible for the license amendment (if needed) for the modified cask; the program would assist in this activity. The national laboratory would be responsible for other regulatory actions necessary to perform the confirmatory program (e.g., safety analysis reviews, arrangements for spent fuel disposition at the end of the program, etc.).

- The spent fuel for the demonstration would need to identified and acquired.

- The utility and/or fuel vendor would examine the spent fuel in the spent fuel pool prior to shipping. A sibling $\operatorname{rod}(\mathrm{s})$ to those shipped to the national laboratory would be stored separately to provide a baseline comparison at the end of the demonstration period. The sibling rod(s) could be stored in the utility spent fuel pool or at the laboratory.

- The utility would be responsible for loading the spent fuel for shipment to the national laboratory.

- The confirmatory program would be responsible for shipping the spent fuel and costs.

- The spent fuel would be transferred from the shipping cask to the storage system.

- The spent fuel would be monitored during the demonstration period ( $\geq 5$ years).

- Selected spent fuel would be retrieved from the storage system and the sibling rod(s) set aside at the beginning of dry storage. Nondestructive and destructive examinations would be performed to identify changes that occurred during dry storage. Of particular interest would be dimensional changes during dry storage and characterizing the mechanical properties of the cladding after irradiation and after dry storage.

- Arrangements would be made for disposition of the spent fuel.

As discussed in Section 3, the combination of INEEL and ANL-W appears to be best suited for implementing this option. For receiving the spent fuel and performing the storage demonstration, INEEL has extensive experience with handling several cask systems because it was the cask demonstration site for the OCRWM demonstration program of the 1980s. TAN, at INEEL, has an overhead crane that is able to handle metal casks and spent fuel canisters. However, the overhead crane would not have sufficient capacity to handle concrete storage modules. Likewise, its 
cask transporter can handle top-picked metal casks but would not have sufficient breadth to handle vertical concrete system such as produced by Holtec or NAC International. Even with these limitations, the INEEL recently loaded TMI-2 fuel into canisters and placed them in NUHOMS storage casks at an onsite ISFSI. Nevertheless, handling the larger dry storage systems would be an issue at all the national laboratory sites.

For examining the spent fuel rods, ANL-W has facilities in place and experience with handling and examining full-length fuel rods, particularly for conducting nondestructive examinations. The other national laboratories, although with good examination capabilities, would need to make facility modifications or devise work-arounds in some of the desired examinations to handle full-length rods. ORNL anticipates having full-length fuel rod handling capabilities in place by June 2004. Because of various examination capabilities among the national laboratories, it may be reasonable to send samples to other laboratories for specific examinations. A particular example is the mechanical testing capabilities in place at ANL-E.

There are two major concerns with the INEEL/ANL-W option. First, there is a question about whether the TAN facility will be operating as long as needed to complete the demonstration. This facility had been scheduled for closure; however, because of the recent transfer of management responsibility for INEEL from DOE-EM to DOE-NE, the future use of TAN is being reconsidered. The second concern is over the Idaho Settlement Agreement between the State of Idaho and DOE. This agreement controls materials that can be brought to the INEEL site. There are two relevant sections in the agreement regarding spent fuel that may also be in conflict: 1) no shipping of commercial spent fuel into the state and 2) allowing spent fuel for research as long as it leaves the state within five years. At this time, these two sections prevent doing some of, or all, the confirmatory program in Idaho. INEEL and ANL-W are pursuing discussions with Idaho about this issue.

INEEL is not the only laboratory that would be challenged by the program. PNNL is facing uncertainty concerning the future of its analytical laboratory that would be used for the fuel and hot cladding examinations. PNNL, ORNL, and SRS would require facility modifications to handle full-length fuel assemblies and large storage systems.

\subsection{Funding and Schedule}

Funding considerations include the following:

- Cost of a storage container (cask or module) including modifications of a standard design to allow temperature measurement of the fuel during storage and cover gas sampling, etc.

- Cost associated with getting spent fuel to the storage site, especially if the site is not an existing ISFSI.

- Cost of obtaining exemptions from certified cask/storage system designs to accommodate the needs of the testing.

- Augmentation of a storage site to accommodate the storage container used for the demonstration. 
- Maintenance and surveillance of the site for the duration of the demonstration ( $\geq 5$ years).

- Pre-test interim and post-test nondestructive and destructive characterization of the spent fuel.

- Possible storage container disposal cost.

- Disposal of the fuel and fuel samples at the conclusion of the demonstration.

A rough estimate of these costs is found in Table 4-1. The least expensive option is to augment an existing effort at a utility through increasing the amount of cladding material characterization, and mechanical and fracture testing. The costs for performing the dry storage demonstration at a utility with examination at an offsite laboratory on one hand and shipping fuel and conducting the program at a national laboratory site on the other hand are about the same, except for

Table 4-1

Estimated Costs for Confirmatory Program Options (\$M)

\begin{tabular}{|l|c|c|c|}
\hline \multicolumn{1}{|c|}{ Activity } & $\begin{array}{c}\text { Augment Existing } \\
\text { Utility Examination } \\
\text { Programs }\end{array}$ & $\begin{array}{c}\text { Dry Storage at an } \\
\text { Utility ISFSI followed } \\
\text { by Laboratory } \\
\text { Examination }\end{array}$ & $\begin{array}{c}\text { Laboratory Storage } \\
\text { and Examination }\end{array}$ \\
\hline Program management $^{(\mathrm{a})}$ & 1.0 & 4.0 & 4.0 \\
\hline Demonstration storage system $^{(\mathrm{b})}$ & 0.0 & 4.5 to $5.5^{(\mathrm{c})}$ & $6.6^{(\mathrm{d})}$ \\
\hline Pool-side NDE $^{|c|}$ & $>0.0^{(\mathrm{e})}$ & $>0.2^{(\mathrm{f})}$ & $>0.2^{(\mathrm{g})}$ \\
\hline Shipping to national laboratory & 0.3 & 0.3 & 1.5 \\
\hline $\begin{array}{l}\text { Dry storage demonstration period with } \\
\text { periodic monitoring and surveillance }{ }^{(\mathrm{i})}\end{array}$ & 0.0 & 1.5 & $41.0^{(\mathrm{h})}$ \\
\hline Post-storage fuel rod examination & $3.0^{(\mathrm{j})}$ & 4.0 to $7.0^{(\mathrm{k})}$ & 4.0 to $7.0^{(\mathrm{k})}$ \\
\hline Post-test disposal and clean-up & 1.0 & 1.0 & $>1.0^{(\mathrm{l})}$ \\
\hline TOTAL & $\$ 5.3 \mathrm{M}$ & $\$ 15.5 \mathrm{M}$ to $>\$ 19.5 \mathrm{M}$ & $\$ 17.6 \mathrm{M}$ to $>\$ 21.3 \mathrm{M}$ \\
\hline
\end{tabular}

(a) Includes management and planning, quality assurance, reviews, reporting, records, contracting, etc.

(b) Includes procuring storage system, physical modifications, licensing, labor for loading, etc.

(c) Includes cost estimate to return fuel to a standard storage system after removing fuel selected for PIE.

(d) Includes additional licensing and issues such as NEPA, safety analysis reports, etc., necessary for performing the demonstration on a laboratory site.

(e) May not be necessary to augment the examinations already planned by the utility.

(f) Likely perform poolside examinations both before and after the dry storage demonstration period.

(g) May select fuel from more than one source, thus requiring more than one set of poolside examinations.

(h) May select fuel from more than one source, thus requiring more than one shipping operation.

(i) Assumes regular surveillance and maintenance, with temperature monitoring and backfill gas analyses, but not interim fuel rod examinations. Also includes post-storage examination of the storage system.

(j) Augment planned examinations and obtain cladding mechanical property data.

(k) Nondestructive, destructive, and cladding mechanical property data; upper range of cost estimate is to make modifications to receive and examine full-length fuel rods depending on where the examinations are performed.

(I) Cost will be dependent on how many fuel rods have to be disposed, and in what manner. 
disposition of the spent fuel. Presumably, the disposal of spent fuel assemblies left at a utility would come under the Nuclear Waste Policy Act and has already been paid for by the utility. The disposal path and cost of disposal of spent fuel sent to a national laboratory is not as straightforward. That is why it has been estimated as $>\$ 1 \mathrm{M}$ for the national laboratory demonstration option. There may also be a need for facility modifications that would be needed by the laboratories to receive and handle full-length fuel rods/assemblies.

The estimated schedules associated with the three options for the confirmatory program are provided in Figures 4-1 through 4-3. The option with the shortest duration is for augmented fuel examination in an existing utility program. The option with the longest duration is for a demonstration at a national laboratory.

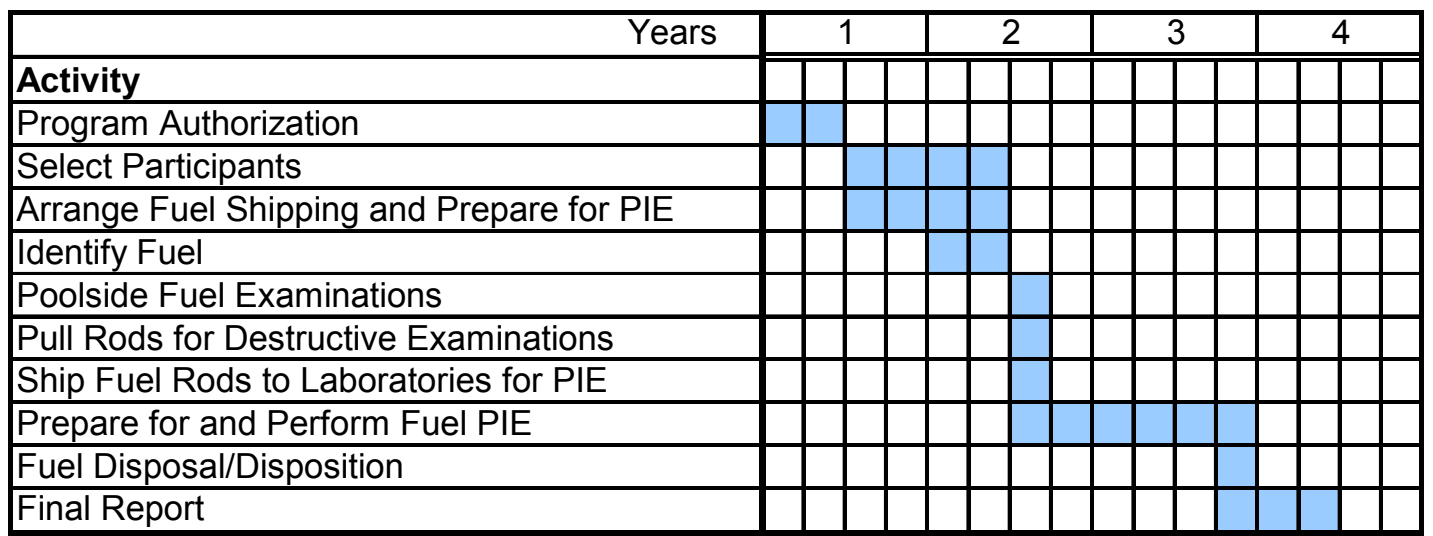

Figure 4-1

Schedule for Augmentation of an Existing Utility Program 


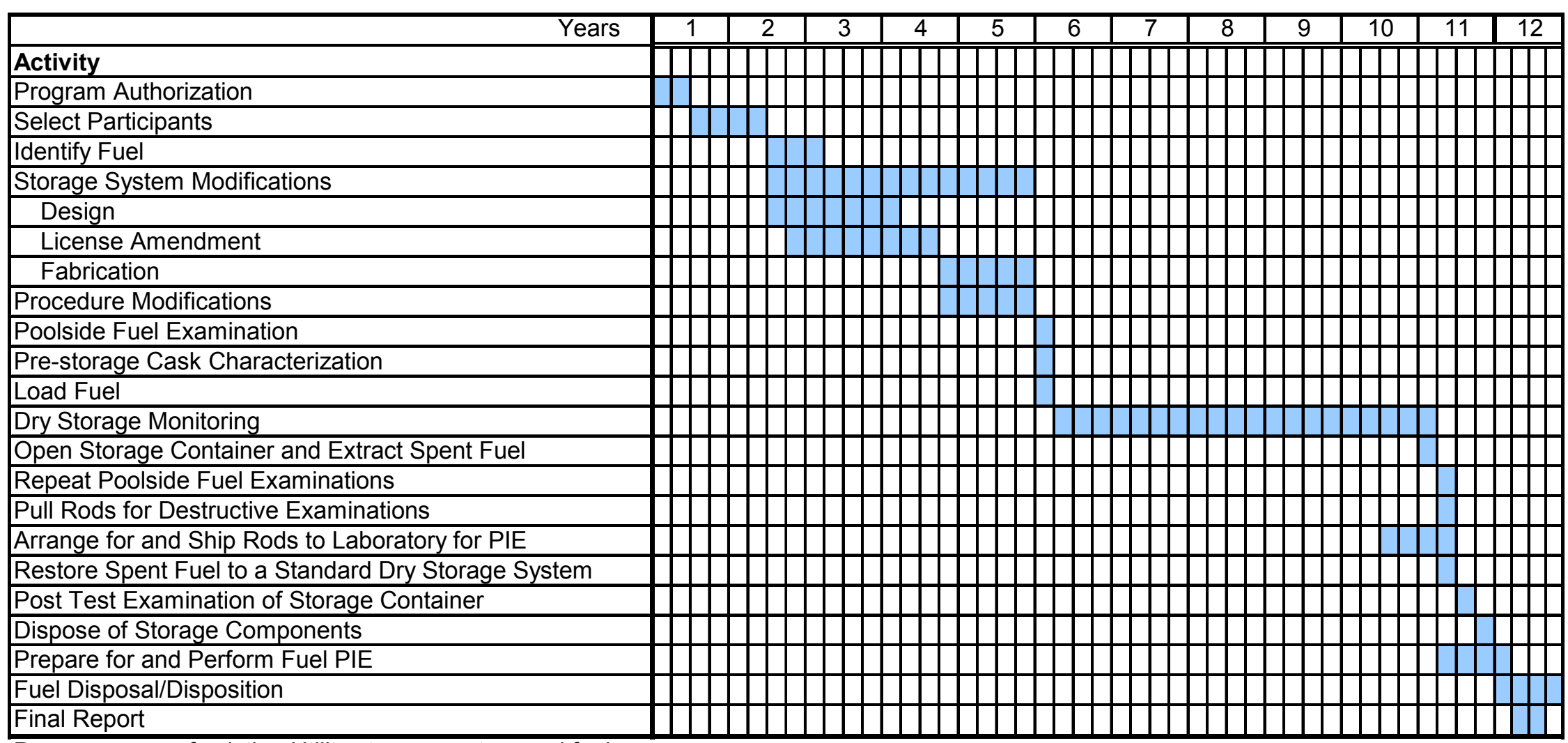

Presumes use of existing Utility storage system and fuel Limits fuel and storage system selection

Allows use of existing operating procedures

Requires license amendment for modification of storage system

Fuel returned to standard storage system at the conclusion of the demonstration Modified component disposed of as low level waste

Laboratory only receives fuel to be examined

Reduces laboratory inventory of spent commercial fuel

Reduces time between receipt and disposal/disposition of spent fuel at a laboratory

Figure 4-2

Estimated Schedule for Demonstration at an Existing Utility ISFSI Site 


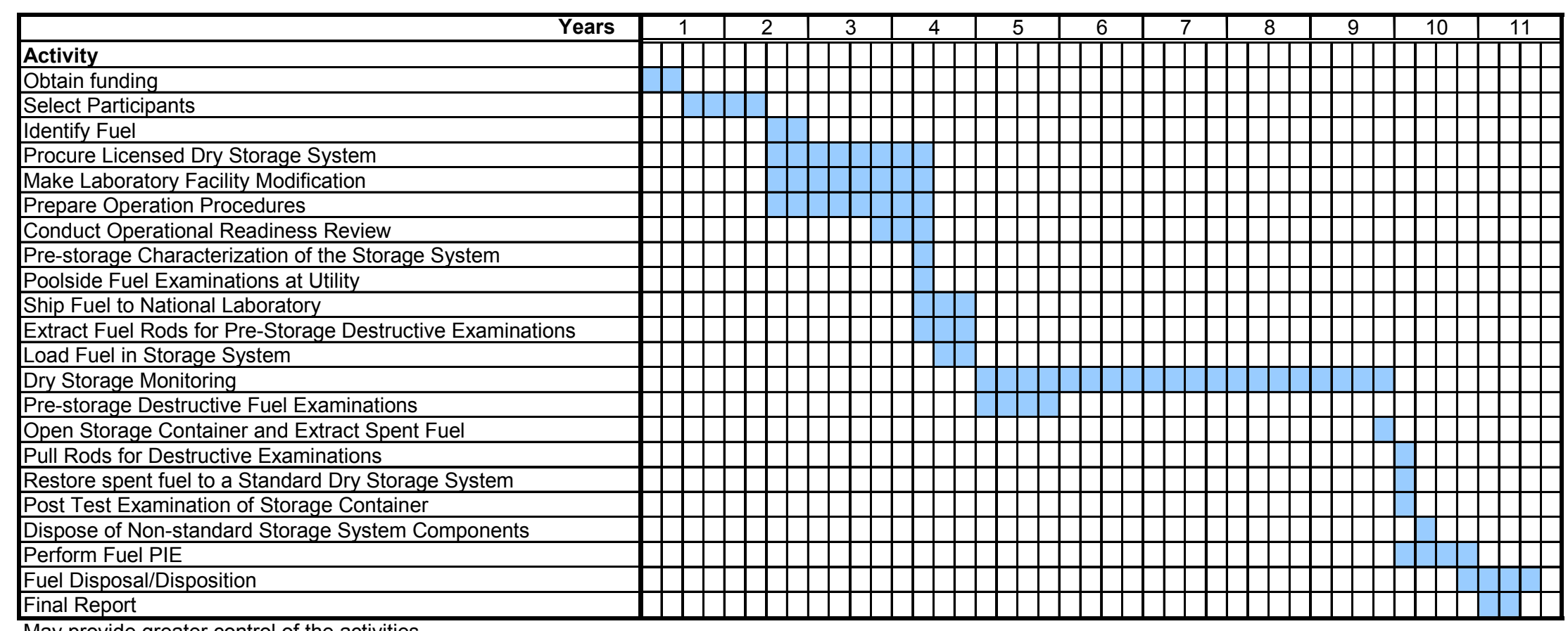

May provide greater control of the activities

Requires modification to facilities for handling large casks

Allows more than one fuel type

May leave the Laboratory with a large inventory of spent commercial fuel

May require modification of state laws

Figure 4-3

Estimated Schedule for Demonstration at a National Laboratory 



\section{5 \\ CONCLUSIONS}

Casks for dry storage of spent fuel were initially licensed for burnup of about $35 \mathrm{GWd} / \mathrm{MTU}$. Over the last two decades the discharge burnup of fuel has steadily increased, with the average discharge burnup now exceeding $45 \mathrm{GWd} / \mathrm{MTU}$. With spent fuel burnups approaching the current peak rod burnup limit of $62 \mathrm{GWd} / \mathrm{MTU}$ and some lead test assemblies burned beyond this limit, the need for a confirmatory dry storage demonstration program was first identified after the publication in May 1999 of NRC's Interim Staff Guidance 11 (ISG-11). With the publication in July 2002 of the second revision of ISG-11, the desirability for such a program further increased in order to obtain confirmatory data about the potential changes in cladding mechanical properties induced by dry storage, which would have implications to the transportation, handling, and disposal of high-burnup spent fuel. Therefore, this feasibility study was performed to examine the options available for conducting a confirmatory experimental program supporting dry storage, transportation, and disposal of spent nuclear fuel with burnups well in excess of $45 \mathrm{GWd} / \mathrm{MTU}$. The following are the conclusions resulting from this feasibility study.

A confirmatory demonstration program is needed based on the following.

- For the most part, the current licensing basis for dry storage of spent fuel is largely based on fuel examinations and dry storage performance demonstrations performed in the 1980s and 1990s. Spent fuel used in the dry storage performance demonstrations had discharge burnups of $\sim 36 \mathrm{GWd} / \mathrm{MTU}$, or less.

- A large database exists for fuel with burnup less than $45 \mathrm{GWd} / \mathrm{MTU}$. There is a more limited, but growing database for spent fuel with burnup greater than $45 \mathrm{GWd} / \mathrm{MTU}$. The data show that cladding oxidation, hydriding, and hoop stresses increase with burnup, especially for high-duty fuel cycles. By and large, the objectives for data collection have been driven by in-reactor fuel performance and not by dry storage, transportation, or disposal considerations. For example, there is a large body of data and model development on inreactor irradiation creep, but much less information is available on post-irradiation thermal creep. The radiation environment existing in the reactor core determines the former, while the temperature field in the storage, transportation, or disposal package dominates the latter. Therefore, uncertainty exists on how the burnup-dependent properties impact the integrity of the fuel during dry storage and how dry storage affects cladding properties that could impact transportation, handling at the repository site, and eventually disposal.

- Several canister-based systems have now been licensed for dry storage of spent fuel up to burnup levels licensed by the NRC for commercial power plant applications (peak rod burnup of $62 \mathrm{GWd} / \mathrm{MTU}$ ), based on the acceptance criteria specified in ISG-11 Rev. 2 . Although the canisters in these systems are intended to be used for transportation, they are not currently licensed for transportation to this burnup level. Current NRC guidance states 
that the transportation of spent with burnups in excess of $45 \mathrm{GWd} / \mathrm{MTU}$ will be handled on a case-by-case basis. This introduces a large financial risk into an interim storage strategy relying on dual-purpose systems.

- To minimize operational risks and lower costs, utilities can be expected to send the highburnup fuel directly from their spent fuel pools to the repository. Under those conditions, DOE will assume responsibility for dry storage until the spent fuel is ready to be disposed.

There is an interest in performance of a confirmatory dry storage demonstration.

- This study evolved out of a need identified by EPRI, and endorsed by a coordinating committee responsible for assigning priorities to candidate projects for the NEPO program.

- Utilities are discharging spent fuel with increasing burnup. Their interest is generated out of the need to reap the full value out of dual-purpose systems, i.e., the ability to store spent fuel and to transport the fuel to a repository without having to repackage it.

- The NRC is interested in confirmatory R\&D providing additional confidence to the regulatory guidance implemented for storage and to be eventually implemented for transportation, including obtaining data on advanced claddings and on mechanical properties relevant to hypothetical transportation accident conditions.

- DOE is interested because disposal in a geologic repository will require management of the spent fuel shipped from the utility sites. This will require spent fuel assembly handling for packaging or re-packaging in dry storage or disposal systems. Knowledge of the characteristics of the spent fuel will be required to safely conduct all required operations.

There are resources available to perform a demonstration.

- Six utilities with existing ISFSIs, four dry storage system vendors, two fuel vendors, and six national laboratories were contacted as part of this study. Each expressed interest in supporting a demonstration program.

- The utilities' interest increases with increased prospect of removing fuel from their site and decreases to the degree that normal site operations are disrupted.

- Spent fuel with the desired burnup/duty cycle is available at selected utilities. When the fuel leaves the utility site, it becomes the property of others and cannot be returned to the utility.

- Fuel remaining at the utility will eventually be sent to the repository, so disposal does not result in additional cost. Fuel shipped to a national laboratory becomes DOE's, and its disposal will incur incremental costs. Consequently, all national laboratories will require a plan to deal with disposal of the spent fuel before it can be accepted for storage or examination.

- License amendments will be required for the dry storage system to allow monitoring of fuel temperatures and collection of fill gas samples, and, possibly, for exceeding licensing limits, such as peak cladding temperature limits.

- INEEL (TAN) and ANL-W (HFEF) are equipped to handle casks and full-length fuel rods but have problems with Idaho over receiving spent fuel. Facility modifications would be 
required at the other national laboratories to receive, store, and handle full-length spent fuel. ORNL may be able to handle full-length fuel rods by June 2004.

Three options were considered by this study. They are:

- Augmentation of an existing utility fuel examination program. Several utilities, in cooperation with fuel vendors, conduct programs to characterize in-reactor fuel performance. The opportunity exists to augment testing of the spent fuel sent to a hot cell to support the data needs driven by dry storage and transportation. While the option does not provide results for fuel that has been in dry storage, it does allow development of a database that supports the condition of the spent fuel at the time it goes into spent fuel storage. It would also allow additional testing on mechanical and fracture properties of the spent fuel.

- Perform the demonstration at an existing ISFSI and conduct PIE at a national laboratory. This option would use a fuel vendor to perform poolside examination of the spent fuel before storing it at a utility's ISFSI. A license amendment would be obtained from the NRC for storage system modifications to accommodate temperature measurements, gas sampling, and possibly exceeding some current licensing limits. At the conclusion of dry storage, some of the spent fuel would be shipped to a national laboratory for examination to determine the effects of dry storage on the mechanical properties of the cladding.

- Perform the demonstration and PIE at a national laboratory. A poolside nondestructive examination would be performed by the fuel vendor at the utility spent fuel pool prior to shipment to a national laboratory, where it would be stored. A modified dry storage system or transportation cask could be used for the dry storage demonstration. After dry storage, the spent fuel would be examined and the effects of dry storage on the mechanical properties of the cladding determined.

\section{Other Items}

- The time and cost requirement of the demonstration activities are estimated to be from five years and $\$ 5 \mathrm{M}$ for augmentation of an existing utility program to over 11 years and $\$ 21 \mathrm{M}$ for a dry storage demonstration at a utility or national laboratory.

- There are precedents for DOE, NRC, and industry to collaborate/share expenses on programs generating data needed by all participants. To avoid potential conflicts of interest, all participants agree on the program, receive the data, and are independently responsible for their own analyses and interpretation/application of the data. 



\section{6 \\ REFERENCES}

ANS. 1997. International Topical Meeting on Light Water Reactor Fuel Performance, Portland, OR. American Nuclear Society.

ANS. 2000. International Topical Meeting on Light Water Reactor Fuel Performance, Park City, UT. American Nuclear Society.

Bare WC and LD Torgerson. 2001. Dry Cask Storage Characterization Project - Phase 1: CASTOR V/21 Cask Opening and Examination. NUREG/CR-6745, U.S. Nuclear Regulatory Commission, Washington, DC.

Barner JO. 1985. Characterization of LWR Spent Fuel MCC-Approved Testing MaterialATM-101. PNL-5109 Rev 1, Pacific Northwest Laboratory, Richland, WA.

Barner JO, ME Cunningham, MD Freshley, and DD Lanning. 1990. High Burnup Effects Program - Final Report. DOE/NE/34046-1 (HBEP-61(3P27)), Battelle Pacific Northwest Laboratories, Richland, WA.

Beedle R. December 17, 1999. Industry Spent Fuel Management. Nuclear Energy Institute.

Brach EW. 2003. "Status of NRC Licensing of Spent Fuel Storage Technologies in the United States." Spent Fuel Management Seminar XX. Institute of Nuclear Materials Management, Northbrook, IL.

Brookmire T. January 2003. "Status of Dominion's Dry Storage Projects." Spent Fuel Management Seminar XX. Institute of Nuclear Materials Management, Northbrook, IL.

Creer JM, RA McCann, MA McKinnon, JE Tanner, ER Gilbert, RL Goodman, D Dziadosz, EV Moore, DH Schoonen, M Jensen, and C Mullen. 1986. The Castor-V/21 PWR Spent-Fuel Storage Cask: Testing and Analyses. EPRI NP-4887, Electric Power Research Institute, Palo Alto, CA.

ENS. March 16, 2003. ENS TopFuel 2003. European Nuclear Society, Würzburg, Germany.

Garde AM, GP Smith, and RC Pirek. 1996. "Effects of Hydride Precipitate Localization and Neutron Fluence on the Ductility of Irradiated Zircaloy-4," ER Bradley and GP Sabol, eds. Zirconium in the Nuclear Industry-Eleventh International Symposium, pp. 407-30. American Society for Testing and Materials. 
Gruss KA. 2002. U.S. Experience with Dry Cask Storage, a Regulator's Perspective. MA McKinnon, ed. U.S. NRC, Rockeville, MD.

Guenther RJ, DE Blahnik, and NJ Wildung. 1994. Radiochemical Analyses of Several Spent Fuel Approved Testing Materials. PNL-10113, Pacific Northwest Laboratory, Richland, WA.

Guenther RJ, DE Blahnik, TE Campbell, UP Jenquin, JE Mendel, LE Thomas, and CK Thornhill. 1988a. Characterization of LWR Spent Fuel MCC-Approved Testing Material-ATM-103. PNL-5109-103, Pacific Northwest Laboratory, Richland, WA.

Guenther RJ, DE Blahnik, TK Campbell, UP Jenquin, JE Mendel, and CK Thornhill. 1988b. Characterization of LWR Spent Fuel MCC-Approved Testing Material--ATM-106. PNL-5109-106, Pacific Northwest Laboratory, Richland, WA.

Guenther RJ, DE Blahnik, TK Campbell, UP Jenquin, JE Mendel, LE Thomas, and CK Thornhill. 1991a. Characterization of LWR Spent Fuel MCC-Approved Testing Material-ATM-105. PNL-5109-105, Pacific Northwest Laboratory, Richland, WA.

Guenther RJ, DE Blahnik, UP Jenquin, JE Mendel, LE Thomas, and CK Thornhill. 1991b. Characterization of LWR Spent Fuel MCC-Approved Testing Material--ATM-104.

PNL-5109-104, Pacific Northwest Laboratory, Richland, WA.

Hunter I. 2003. "TN Experience in Spent Fuel Storage and Transportation Using Metal Casks." Spent Fuel Management Seminar XX. Institute of Nuclear Materials Management, Northbrook, IL.

Kaiser RS. April 2000. "The Fuel Duty Index (FDI)-A New Performance Measure of Fuel Rod Cladding Performance." International Topical Meeting on Light Water Reactor Fuel Performance, Park City, UT. American Nuclear Society.

Kimball C and M Billone. 2003. Dry Cask Storage Characterization Project. EPRI Report 1002882, Electric Power Research Institute, Palo Alto, CA.

Knott KP, RL Kesterson, LG Hallstadius, MY Young, and B Johansen. 2003. "Advanced PWR Fuel Designs for High Duty Operation.” ENS TopFuel 2003. European Nuclear Society, Würzburg, Germany.

Manzel R and C Walker. April 2003. "High Burnup Fuel Microstructure and its Effect on Fuel Rod Performance." 2003. International Topical Meeting on Light Water Reactor Fuel Performance, Park City, UT. American Nuclear Society.

McKinnon MA, JW Doman, JE Tanner, RJ Guenther, JM Creer, and CE King. 1986. BWR Spent Fuel Storage Cask Performance Test, Volume I: Cask Handling Experience and Decay Heat, Heat Transfer, and Shielding Data. PNL-5777 Vol. I, Pacific Northwest National Laboratory, Richland, WA. 
McKinnon MA and VA Deloach. 1993. Spent Nuclear Fuel Storage-Performance Tests and Demonstrations. PNL-8451, Pacific Northwest Laboratory, Richland, WA.

Morel M, P Melin, and A Dumont. 1994. "Updated Status of In-Reactor Experience of FRAGEMA Fuel Products." 1994 International Topical Meeting on Light Water Reactor Fuel Performance. American Nuclear Society, West Palm Beach, FL.

NEI. April 23, 2002. "U.S. Generating Companies with On-Site Dry Storage Commitments." World Wide Web. Nuclear Energy Institute.

NRC. 1997. Standard Review Plan for Dry Cask Storage Systems. NUREG-1536, U.S. Nuclear Regulatory Commission, Washington, DC.

NRC. 1998. Interim Staff Guidance - 2, Fuel Retrievability. U.S. Nuclear Regulatory Commission, Washington, DC.

NRC. 1999a. Interim Staff Guidance - 11, Storage of Spent Fuel Having Burnups in Excess of 45,000 MWd/MTU. U.S. Nuclear Regulatory Commission, Washington, DC.

NRC. 1999b. Interim Staff Guidance - 5, Revision 1, Confinement Evaluation. U.S. Nuclear Regulatory Commission, Washington, DC.

NRC. 2000a. Standard Review Plan for Spent Fuel Dry Storage Facilities. NUREG-1567, U.S. Nuclear Regulatory Commission Spent Fuel Project Office, Office of Nuclear Material Safety and Safeguards, Washington, DC.

NRC. 2000b. Standard Review Plan for Transportation Packages for Spent Nuclear Fuel. NUREG-1617, U.S. Nuclear Regulatory Commission Spent Fuel Project Office, Office of Nuclear Material Safety and Safeguards, Washington, DC.

NRC. 2000c. Transportation and Storage of Spent Fuel Having Burnups in Excess of 45 $G W D / M T U$. Interim Staff Guidance - 11, Revision 1, U.S. Nuclear Regulatory Commission, Washington, DC.

NRC. 2001. Materials Evaluation. Interim Staff Guidance - 15, U.S. Nuclear Regulatory Commission, Washington, DC.

NRC. 2002a. Interim Staff Guidance - 1, Revision 1, Damaged Fuel. U.S. Nuclear Regulatory Commission, Washington, DC.

NRC. 2002b. Transactions of the 2002 Nuclear Safety Research Conference. NUREG/CP0178, U.S. Nuclear Regulatory Commission, Washington, DC.

NRC. 2002c. Cladding Considerations for Transportation and Storage of Spent Nuclear Fuel. Interim Staff Guidance - 1, Revision 2, U.S. Nuclear Regulatory Commission, Washington, DC. 
NRC. 2003. Interim Staff Guidance - 19, Moderator Exclusion under Hypothetical Accident Conditions and Demonstrating Subcriticality of Spent Fuel under the Requirements of 10 CFR 71.55[e]. U.S. Nuclear Regulatory Commission, Washington, DC.

Ruzauskas J and KN Fardell. 2001. Design, Operation, and Performance Data for High Burnup PWR Fuel from the HB Robinson Plant for Use in the NRC Experimental Program at Argonne National Laboratory. EPRI Report 1001558, Electric Power Research Institute, Palo Alto, CA.

Shakir S. January 2003. "Transnuclear's Spent Fuel Storage and Transportation Technologies." Spent Fuel Management Seminar XX. Institute of Nuclear Materials Management, Northbrook, IL.

Siemens Power Corporation ND. 1996. "Siemens Power Corporation Reactor Services \& Systems Briefing Book.” Siemens Power Corp., Nuclear Division, Richland, WA.

Tsai H and M Billone. 2002. Characterization of High-Burnup PWR and BWR Rods, and PWR Rods after Extended Dry-Cask Storage. NUREG/CP-0178, Nuclear Regulatory Commission, Washington, DC. 
$\boldsymbol{A}$

NATIONAL LABORATORY RESPONSES TO PNNL SURVEY QUESTIONNAIRE

Provided in this appendix is a compendium of the national laboratory responses to PNNL's survey questionnaire. Also provided, prior to the responses, is the introductory portion of the survey questionnaire, which is not included with each laboratory's response. 

National laboratory responses to pnnl survey questionnaire

\section{Introduction to PNNL Survey Questionnaire}

\section{Dry Storage of Spent Fuel with Burnup in Excess of 45 GWd/MTU}

\section{Project Scope}

There is interest in conducting a confirmatory experimental program supporting regulatory acceptance for storing spent fuel with burnup in excess of $45 \mathrm{GWd} / \mathrm{MTU}$ under a dry, inert atmosphere. Pacific Northwest National Laboratory (PNNL) has been charged with examining options, capabilities, costs, and other factors relevant to conducting such an experimental program. Potential participants from industry (fuel vendors, reactor operators, and spent fuel storage vendors) and the national laboratories are being surveyed as to interest and capabilities.

\section{Background}

Casks for the dry storage of spent fuel were initially licensed for burnups on the order of $35 \mathrm{GWd} / \mathrm{MTU}$. Over the last two decades the discharge burnup of fuel has steadily increased, with future discharge burnups expected to be well beyond current licensing criteria. Starting in 2001 for PWRs and in 2002 for BWRs, the majority of the assemblies to be discharged in any given year will be characterized by assembly-average burnups greater than $45 \mathrm{GWd} / \mathrm{MTU}$. By 2007, over $90 \%$ of assemblies to be discharged will have burnups greater than $45 \mathrm{GWd} / \mathrm{MTU}$. The current limit for assembly-average burnup is $62 \mathrm{GWd} / \mathrm{MTU}$.

The U.S. Nuclear Regulatory Commission (NRC) has issued Interim Staff Guidance (ISG-11) addressing the storage and transportation of high-burnup spent fuel. The guidance is evolving as the NRC staff continues their review of data and technical reports to further understand the mechanical and fracture toughness properties of spent fuel cladding. Until further guidance is developed, the NRC indicates that the transportation of high-burnup commercial spent fuel will be handled on a case-by-case basis. Experimental validation of the behavior of high-burnup spent fuel rods and assemblies under prototypical conditions will be needed to confirm proposed technical bases and to support regulatory acceptance. Failure to resolve issues associated with the storage of high-burnup fuel in dual-purpose storage systems is likely to result in licensing delays, which will result in economic penalties and operational limitations in spent fuel pools and in dry storage options.

\section{Approach}

The scope of the current work is to survey potential participants and then prepare a plan for the proposed demonstration project to store high-burnup spent nuclear fuel in a dry, inert environment. The plan will address the feasibility of the demonstration program and will recommend one or more scenarios based on the availability of demonstration sites, high-burnup fuel, fuel examination capabilities, institutional considerations, and detailed cost estimates.

The plan will identify fuel and fuel examination capabilities; the conduct of pre-storage characterization of the spent fuel and storage system (cask) using destructive and nondestructive 
methods to establish a baseline; the monitoring of cask cover gas for fission gas release and fuel cladding temperatures, the conduct of interim and post storage nondestructive and destructive examinations of the spent fuel and cask; and the demonstration of fuel retrieval. It is anticipated that interim and post-storage examinations of the fuel would be similar to the pre-storage examinations. Interim fuel examination would be triggered by a significant increase in fission gas release in the inert cover gas during dry storage. The demonstration is to provide confirmatory data on heat transfer, fuel integrity, cladding deformation, fuel retrievability, and cladding properties following dry storage.

The plan will also identify locations and organizations that would be amenable to participating in the demonstration and fuel examinations. The plan will identify activities that can be supported by the NRC, utilities, fuel vendors, and cask vendors. DOE's, NRC's and EPRI's guidance and concurrence will be sought in developing the demonstration plan. This project is intended to lead to a demonstration program that will generate experimental data to confirm the technical basis for storing spent fuel with burnup in excess of $45 \mathrm{GWd} / \mathrm{MTU}$ under a dry, inert atmosphere.

The envisioned scope of the potential demonstration project, for the purpose of providing potential participants information on which to be able to respond, includes the following points:

- load the spent fuel into the storage cask and begin the storage phase of the demonstration in FY-2005 or FY-2006

- $\quad$ store spent fuel with burnup $>45 \mathrm{GWd} / \mathrm{MTU}$ and preferably $>60 \mathrm{GWd} / \mathrm{MTU}$

- store the spent fuel near the regulatory temperature limit of $400^{\circ} \mathrm{C}$

- $\quad$ store the spent fuel for a minimum of 5 years and a maximum of 10 years

- modify the spent fuel storage cask to allow monitoring of the cover gas (to detect fuel rod failures) and fuel cladding temperatures; obtain any necessary NRC exemptions

- obtain pre-test characterization examination data on the spent fuel and the storage cask (but the spent fuel is the principal object of interest)

- retrieve and conduct interim examinations on the spent fuel if monitoring data indicates a need to do so

- conduct post-test examinations of the spent fuel; characteristics of principal interest include:

- dimensional changes during storage, particularly diameter increases due to creep

- changes in cladding corrosion or hydrogen pickup during storage

- evidence of delayed hydride cracking

- changes in mechanical properties of the irradiated cladding

- arrange final disposition of the spent fuel and storage cask (it is anticipated that final disposition of any commercial spent fuel received at a national laboratory or waste generated during spent fuel examinations would become the responsibility of the national laboratory). 


\section{Questionnaire for National Laboratories}

DOE's national laboratories are being considered for pre-and post-test characterization of the spent fuel used in a possible high-burnup spent fuel storage demonstration and also as a site for conducting the demonstration. The following questions are provided to address your potential interest in participating in the demonstration, what areas of the demonstration you would be interested in, and what capabilities your site has, and to solicit other information pertinent to your participation in the demonstration.

The possible role of a national laboratory could range from just conducting detailed post-test fuel examinations to serving as the demonstration site in addition to providing fuel examination services. It is assumed that any spent fuel spent to a national laboratory will need to be disposed of by that laboratory.

Demonstration Site: receive demonstration spent fuel cask; receive spent fuel; load/unload spent fuel into demonstration cask; monitor cask cover gas for fission gases; monitor fuel cladding temperatures; dispose of spent fuel at conclusion of demonstration; disposition storage cask at conclusion of demonstration

Fuel Characterization: ability to 1) examine full-length rods/assemblies, 2) remove single rods from assemblies, 3) perform nondestructive and destructive examinations, and 4) dispose of spent fuel at conclusion of examinations.

A response by February 17, 2003 would be sincerely appreciated.

Please respond via mail or e-mail to:

Mitchel Cunningham

Pacific Northwest National Laboratory

MSIN K8-60

P.O. Box 999

Richland, WA 99352

mitch.cunningham@pnl.gov

(509) 372-4987

(509) 372-4989 (fax) 


\title{
ANL-W Response to Survey Questionnaire
}

\author{
National Laboratory: Argonne National Laboratory-West
}

Contact: David S. Duncan

david.duncan@anl.gov

(208) 533-7847

\section{Potential Demonstration Site}

- Are you interested in, or capable of, serving as the demonstration site?

Yes.

If the demonstration concentrates only on the performance of the fuel and not of the cask, a very cost-effective alternative could be developed at ANL-W that would allow all activities associated with the demonstration to occur on the ANL-W site without the need for significant additional equipment or hardware. One of several truck-mounted transportation systems could serve as a test bed for this demonstration if the total number of elements in the demonstration was the equivalent of one fuel assembly or less. From the 1/28/03 response update, it appears as though there may not be a significant amount of fuel currently available that would meet the required burnup levels. This being the case, the NAC NLI-1/2, the NAC-LWT, and FSV-1 casks have the capacity to continuously deal with the heat loads at issue, and the NAC casks are currently licensed to handle PWR and BWR fuel that generates radiation and decay heat resulting from the proposed burnup levels. Upon receipt from a reactor operator, the cask could be unloaded into the Hot Fuel Examination Facility (HFEF) main cell, if pre-demonstration characterization work was stipulated. Following desired nondestructive characterization, the elements would be re-loaded into the shipping cask. The demonstration would then commence with placement of the selected cask, payload, and trailer in its designated test location. Collection of gas samples would be included as part of the demonstration activity. If a low-usage, outdated cask were to be used for the demonstration, it would improve the probability that a cost-effective agreement could be established for its use. An agreement of this nature would likely establish the requirement that DOE be responsible to dispose of the cask following the demonstration. Use of this style of cask would also facilitate periodic NDE of the test elements, a recommendation presented later in the survey.

If requirements of the demonstration stipulate use of a full-scale commercial dry spent fuel storage cask, special transfer equipment would be required to ensure compatibility with load/unload activities and outdoor transfer to the dry storage cask. Currently, ANL-W lacks a fuel processing pool, lifting capacity, and hot cell capacity to load and/or handle commercially available spent fuel dry storage or fuel transfer casks and associated handling equipment. However, arrangements would be made for large-capacity boom cranes to complete the required outdoor transfers and heavy equipment handling. This configuration could be set up to deal with periodic NDE during the duration of the test, but it would present significant cost. The costs for additional handling required to support this activity are presented in the cost estimates. 
- What are the general characteristics of your potential demonstration site? e.g., concrete pad, support facilities, etc.

If transportation casks are used for the demonstration, the cask system (including trailer) could be used as the demonstration site. The system would simply then be isolated by a temporary fence, weather awning, or enclosure to ensure proper security and weather protection during the test.

If a commercial dry storage cask were used, a pad and required utilities would be constructed to accommodate the experiment. Required electricity would be installed to allow active heating of the cask to achieve the necessary thermal condition (if the cask lacked sufficient high-burnup fuel to achieve the required condition). The cask basket would be commercially procured and the cask shielding constructed on-site.

- Do you have existing access to any intact high-burnup spent fuel rods/assemblies? If so, what is the burnup history and level, enrichment, design, or other pertinent information?

See INEEL survey response.

- Are you able to receive full-length fuel assemblies, shipping and storage casks? Can you transload spent fuel from a shipping cask into a demonstration storage cask? What limits do you have on handling shipping casks and storage casks? What are the operational load limits of your cranes that could be used for handling transportation and storage casks?

ANL-W has capacity to ship, receive, and handle full-length PWR and BWR fuel assemblies and rods at HFEF when received in NRC-licensed, truck-mounted transportation casks. Portable heavy lift equipment would be transported to the ANL-W site for lifting and handling dry storage casks and associated handling equipment. Handling of transportation casks would likely be completed in the truck lock of the HFEF, where a 40-Ton overhead crane is located.

- Can you arrange for transportation of selected spent fuel from the reactor to your site if needed? What is your previous experience in arranging for transportation of spent fuel?

Yes.

ANL-W has previous experience in receipt, handling, and shipping of the T-3, T-2, NACLWT, TN-FSV, NRBK-41, WAPD-40, LASL, Jolly Green Giant, Super Tiger, and RM-16 casks. This shipment experience includes extensive coordination with state government, law enforcement, and all concerned stakeholders.

- Can you collect, and then analyze, gases from the storage cask? Gas analysis will require radiochemical gamma analysis in addition to mass spectrometry.

Yes.

ANL-W has the capability to perform both gamma analysis and mass spectrometry on collected gases. ANL-W would perform gas collection activities via sample collection and/or leak test ports for either storage demonstration method. Gas analyses would be performed at the ANL-W analytical laboratory. The ANL-W AL has the capacity to perform 
fission gas, gas composition, total activity, and total tritium analyses. Available analytical methods include liquid scintillation, gas chromatography, and gas mass spectrometry.

\section{Fuel Characterization Site}

- Are you interested in providing fuel examination services?

Yes. See description below for a listing of capabilities.

- What general capabilities do you have for fuel examination? e.g., visual, profilometry, axial gamma scanning, neutron radiography, rod puncture and gas analysis, optical metallography, scanning electron microscopy on irradiated cladding/fuel, transmission electron microscopy on irradiated cladding/fuel, radiochemical gamma analysis, etc.

For nondestructive examination, ANL-W has the capability to perform the following examinations at HFEF on full length PWR and BWR fuel:

1. Neutron radiography, using a 250kw TRIGA reactor.

2. Element axial diameter measurements, using an in-cell element contact profilometer.

3. Element weight.

4. Plenum gas collection and analysis, using the in-cell gas assay, sample and re-charge (GASR) unit to puncture and collect the plenum gas.

5. Element fission and activation product distribution, using PGS-III, a precision axial gamma scan instrument.

6. Element bow and length measurement, using an in-cell bow and length machine.

7. Element Visual Examination, using an in-cell visual examination machine.

8. Through-window macro-photography, using a high-resolution digital camera, processing computer, and high-resolution printer.

For destructive examination, ANL-W has the capacity to perform the following:

1. Large-component disassembly and sample preparation, employing an in-cell CNC milling machine.

2. Metallographic sample mounting and preparation, using low speed Buehler ${ }^{\circledR}$ polishing wheels and Syntron ${ }^{\circledR}$ vibratory polishers.

3. Metallography and micro-hardness testing, using a Leitz ${ }^{\circledR}$ Metallograph and a Vickers-type hardness tester.

4. HFEF performs optical microscopy, using an instrument capable of magnifications from $2 \mathrm{X}$ to $800 \mathrm{X}$. 
5. HFEF performs scanning electron microscopy, using an AMRay ${ }^{\circledR}$ 1200B SEM, capable of magnifications from $15 \mathrm{X}$ to $30,000 \mathrm{X}$.

In destructive chemical analysis at ANL-W, the following constituents are routinely measured in samples of oxide, mixed oxide, carbides, nitrides, and metal alloy reactor fuels, including fuel cladding materials:

1. Total and isotopic uranium and plutonium, americium, neptunium, curium

2. density

3. burnup

4. rare earths

5. noble metal fission/activation products

6. retained fission gas

7. carbon, oxygen, nitrogen and other major and minor constituents.

- Are you able to conduct mechanical testing on irradiated cladding? e.g., fracture toughness, creep?

ANL-W has the capacity to fabricate mechanical test specimens from samples and will collaborate with ANL-E's Alpha-Gamma Hot Cell Facility (AGHCF) to complete mechanical testing. AGHCF has the capacity to complete the following tests on fuel cladding:

1. axial tensile and ring stretch tensile testing

2. elevated temperature creep testing (up to $\sim 400^{\circ} \mathrm{C}$ )

3. high pressure creep testing (up to $5000 \mathrm{psi}$ )

4. fracture toughness

5. hardness.

- What capabilities do you have for receiving spent fuel for examination? Are you capable of examining full-length fuel rods/assemblies? If not, what modifications would be necessary to your facility to provide this capability?

ANL-W currently has the capacity to receive full-length commercial spent fuel shipped in licensed, truck-mounted, commercial spent fuel transportation systems. Currently ANL-W is qualified to receive and handle the NAC-LWT and TN-FSV casks. Other licensed transportation systems could be qualified with only minor hot cell interface modifications. Internal cask configuration issues would also need review to determine necessary modifications to hot cell handling equipment. 
- Would you be able to remove individual fuel rods from a fuel assembly for examination?

Yes.

\section{Other Issues Associated with Demonstration Site/Fuel Characterization}

\subsection{Institutional Issues Associated with Participating in the Demonstration Program}

- What restrictions do you have on receiving and accepting commercial spent fuel? Can commercial spent fuel be shipped to your site? Can you accept responsibility for the spent fuel?

Receipt of spent fuel into the state of Idaho has specific restrictions. In 1995, the State reached an agreement with DOE in the form of: (State of Idaho), Settlement Agreement and Consent Order, Public Service Company of Colorado v. Batt, No. CV 91-0035-S-EJL (D. Id.), and the United States v. Batt, No. CV 91-0054-S-EJL (D.Id.), October 17, 1995. This consent order restricts inbound and outbound shipment of fuel within the state. Section D.2.e. prohibits shipment of commercial spent fuel into the state. However, without regard to fuel type, Section F.1 of the order allows receipt of undefined amounts of spent fuel into the state for research, as long as it leaves the state within 5 years of its receipt on the INEEL. Recent experience indicates that this apparent conflict of allowances may be negotiable with the Governor and the Department of Energy as long as a specific program and final disposition are well defined prior to the material's entry in the state. The settlement agreement also limits the total number of spent nuclear fuel shipments allowed by DOE for shipment to the INEEL (including ANL-W). ANL-W would coordinate with DOE to ensure that any shipments made under this program did not cause ANL-W and DOE to exceed the total number of shipments allowed by the settlement agreement.

- How would you dispose of the spent fuel after the demonstration project is completed (assuming it cannot be returned to the reactor operator)?

Prior to initiation of the project ANL-W would request DOE to accept ownership responsibility for the fuel based on terms negotiated with the state for its receipt and final disposition.

- What would you do with the storage cask after the demonstration is completed?

If a little-used commercial transportation system was employed for the demonstration, it is likely that ownership of such a system would transfer to DOE following the demonstration, placing disposal responsibility with DOE. If a DOE-owned cask were used, the cask would be returned to service. If a dry storage cask were used, decontamination of the storage basket would be attempted. If decon was successful, the basket would be released as scrap or sold to a commercial utility employing the demonstration cask design for storage activities. If unsuccessful, the basket would be disassembled and disposed-of as LLW. The outer concrete shield would be demolished and disposed-of as clean waste.

- Do you have any potential conflicts of interest if you were to participate in this demonstration project? e.g., NRC, DOE/EM... 
No.

\subsection{Cost and Schedule Issues Associated with Participating in the Demonstration Program}

- How busy are your facilities? Are there any specific windows of opportunity or, conversely, periods when you could not accommodate the proposed work?

The HFEF routinely performs programmatic activities similar to this request. The proposed work program would be planned and scheduled into HFEF operations.

- Are any of the facilities envisioned for this work scheduled for decommissioning? If so, what is the current schedule for that activity?

No.

- What are your gross estimated costs for the work you would be interested in performing? e.g., providing a demonstration site, transportation of spent fuel to/from the site, conducting pre- and post-test fuel examinations, disposing of the spent fuel, disposing of radioactive waste generated from the work, clean-up of facilities used to conduct the work, etc.

For this ROM estimate, the following assumptions and recommendations apply:

1. No destructive pre-demonstration characterization examinations are assumed.

2. For nondestructive examinations, the same suite of exams is planned for pre-and postcharacterization. Periodic NDE of selected elements is also planned at the end of each test year during the demonstration. The results from these periodic exams would be very useful in benchmarking creep models, considered the limiting degradation mechanism in dry cask storage.

Ten rods are assumed to be the pre- and post-examination scope. Though the capacity exists in both test categories, no post-test chemical analysis or mechanical testing of fuel and/or cladding is estimated. No scope was provided.

3. The storage demonstration is performed using two alternatives: 1) a truck-mounted, licensed transportation cask system located at ANL-W and positioned inside a constructed weather enclosure; and 2) a full size dry storage cask, constructed and assembled on the ANL-W site. With a transport cask, the weather enclosure would be constructed as part of site preparations. Hot cell-to-cask interface modifications are also included in site preparations. With a dry storage cask, costs include construction/fabrication of dry cask, design, fabrication, and checkout of fuel transloading equipment for the cask.

4. Site preparations also include necessary 10CFR72 licensing activity. With the transport cask, activity includes a new part 72 application. With the dry storage cask, activity includes a part 72 amendment to include the particulars of the demonstration, potentially including active heating of the storage basket.

5. Less than a full fuel assembly comprises the fuel used for the demonstration. 
6. The demonstration period is 5 years, commencing in FY05. A single gas sample collection and analysis is assumed to occur every 6 months. NDE of selected elements is assumed to occur each year during the test.

7. The cost of cask lease or procurement has not been included in this estimate.

8. A 5\% annual escalation is applied to all demonstration and support activities, beginning in FY03 and extending to all out-years.

\section{Demonstration using spent fuel transport cask}

Project Management

Licensing activity (10CFR72 license application) (Includes cask thermal modeling) \$1,000k

Transport Cask Demonstration site preparations (including shipment receipt)

Pre-demonstration characterization activities

Demonstration (including sample analysis)(not including cask lease or procurement)

Periodic in-test NDE of selected elements (Once per year)

$\$ 2,000 \mathrm{k}$

Post-demonstration characterization activities

$\$ 1,700 \mathrm{k}$

Closure (including shipment to destination repository)

Total

$\overline{\$ 7,500.00}$

\section{Demonstration using dry storage cask}

Project Management

Licensing activity (10CFR72 license amendment)(Includes cask thermal modeling)

$\$ 1,000 \mathrm{k}$

Transport Cask Demonstration site preparations (including shipment receipt)

$\$ 3,250 \mathrm{k}$

Pre-demonstration characterization activities

$\$ 850 \mathrm{k}$

Demonstration (including sample analysis)(not including cask lease or

procurement)

Periodic in-test NDE of selected elements (once per year)

$\$ 2,500 \mathrm{k}$

Post-demonstration characterization activities

$\$ 1,700 \mathrm{k}$

Closure (including shipment to destination repository and disposal of cask)

$\$ 500 \mathrm{k}$

Total

$\overline{\$ 10,550 \mathrm{k}}$

3.3 Please provide any other information that you believe is pertinent to your site and potential participation in this project.

None. 


\section{INEEL Response to Survey Questionnaire}

National Laboratory: Idaho National Engineering Laboratory (INEEL)

Contact: Tom Hill

tjh@inel.gov

(208) 526-1711

\section{Potential Demonstration Site}

- Are you interested in, or capable of, serving as the demonstration site?

Yes, the INEEL is a U.S. Department of Energy (DOE) multi-program national laboratory serving all of the missions of DOE with an emphasis on nuclear energy and national security. The INEEL conducts science, technology, engineering, and program operations for DOE and a variety of other customers.

- What are the general characteristics of your potential demonstration site? e.g., concrete pad, support facilities, etc.

The INEEL is ideally suited as a demonstration site to support experimental validation of the behavior of high-burnup spent fuel rods and assemblies under prototypical conditions. The INEEL is located in southeastern Idaho on 894 square miles of semiarid sagebrush desert.

The INEEL currently manages the Test Area North (TAN) Facility near its northern boundary. The TAN Facility features a Hot Shop with overhead crane lift capacity up to 110 tons. Wall and overhead manipulators provide remote handling coverage of the entire floor space. The Hot Shop is conveniently adjacent to the outside dry cask storage pad connected to the TAN Hot Cell, generally used for handling and disassembly project. An adjacent Warm Shop is used for staging, storage, and handling support to the Hot Shop for low radiation level work. Within the same complex, four additional interconnected examination cells are available. The outside dry storage pads have eight storage locations and are described below.

The hot cell facilities located at TAN perform various handling functions using combinations of the Hot Shop, TAN Hot Cell, Hot Cell Annex, Warm Shop, Storage Pool, and Storage Cask Testing Pad. The plant layout is designed within one complex with interconnections between key areas to provide a controlled environment for remote operations.

The Hot Shop measures 51 feet wide, 165 feet long, and 55 feet high and handles irradiated component using a variety of remotely operated handling equipment, including:

1. $110 / 10$ ton radio controlled bridge crane for moving heavy assemblies

2. Bridge-mounted overhead electromechanical manipulator (PAR 6000)

3. Three wall-mounted manipulators (PAR 3000). 
Taken together, this equipment provides remote handling coverage over the entire floor.

Hot Shop operations are carried out under strict facility work procedures. Contamination levels are maintained at low levels to permit non-remote operation and maintenance when necessary. Operating procedures are written to as-low-as-reasonably-achievable (ALARA) standards to minimize radiation exposure. The Hot Shop has operated safely at radiation levels as high as one million $\mathrm{R} / \mathrm{hr}$.

Outside dry storage is provided using technology developed through the Spent Fuel Storage Cask Testing Program. A concrete storage pad, open to the elements, was constructed for this program. Monitoring equipment is contained in an adjacent metal building and connected to the storage casks for monitoring cask internal pressure and temperature effects from the stored fuel. Hookups are available on the pad for each of the eight cask positions.

The Storage Pool measures 70 feet long, 48 feet wide, and 24 feet deep and is connected to the Hot Shop vestibule through and underwater passage. Materials are moved between the Storage Pool and Hot Shop with an underwater transfer cart.

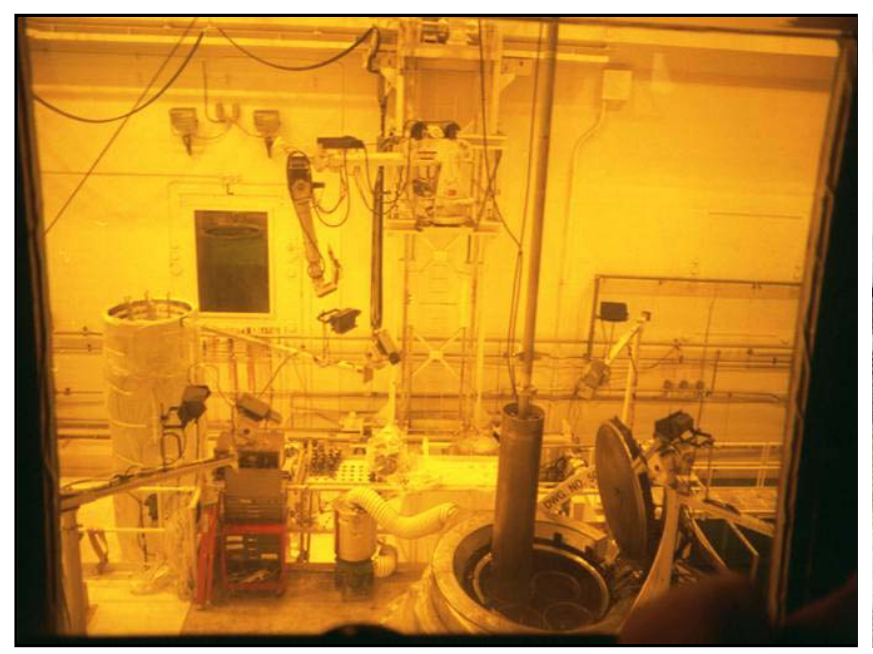

Test Area North Hot Cell Housing TMI-2 Vacuum Drying Project

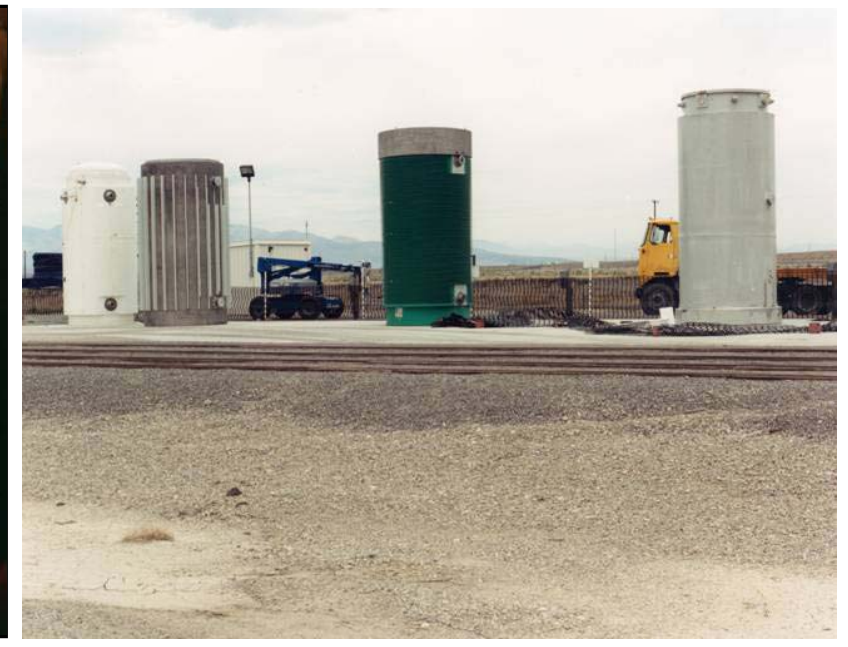

Test Area North Cask Storage Pad

- Do you have existing access to any intact high-burnup spent fuel rods/assemblies? If so, what is the burnup history and level, enrichment, design, or other pertinent information?

No, our highest commercial spent nuclear fuel burnup ranges from 30 to $35 \mathrm{GWd} / \mathrm{MTU}$.

- Are you able to receive full-length fuel assemblies, shipping and storage casks? Can you transload spent fuel from a shipping cask into a demonstration storage cask? What limits do you have on handling shipping casks and storage casks? What are the operational load limits of your cranes that could be used for handling transportation and storage casks?

Yes, the INEEL can receive both rail and truck casks and has demonstrated capability to transload spent nuclear fuel from shipping casks to storage casks using the TAN Hot Shop. 
The INEEL also constructed and demonstrated a dry storage cask transfer system for the NRC.

The INEEL has no known limits on handling shipping casks and storage casks.

The INEEL has a 140-ton mobile cask transporter that has adequate capability to lift and move any commercial dry storage cask; our cranes used for external lifts are adequate for any commercial rail or truck transport cask; and our interior crane in TAN Hot Shop was described above.

- Can you arrange for transportation of selected spent fuel from the reactor to your site if needed? What is your previous experience in arranging for transportation of spent fuel?

Yes. The INEEL has arranged transportation of the spent nuclear fuel for the NRC rod consolidation program, for the TMI-2 fuel shipments, for the FRR fuel receipts to the Idaho Nuclear Technology and Engineering Center, and for the West Valley spent nuclear fuel consolidation at the INEEL. The INEEL also works with other DOE laboratories and universities for shipment of domestic research reactor spent nuclear fuel programs to the INEEL.

- Can you collect and then analyze gases from the storage cask? Gas analysis will require radiochemical gamma analysis in addition to mass spectrometry.

The INEEL currently performs these types of gas sampling and analysis on the commercial dry storage casks at the INEEL as part of the ongoing NRC program. The INEEL has also performed gas sampling on the West Valley Rail Casks containing spent nuclear fuel that are awaiting clearance for transport to the INEEL.

\section{Fuel Characterization Site}

- Are you interested in providing fuel examination services?

The INEEL is interested in performing the type of activities described in this inquiry. The INEEL would perform these tasks in conjunction with the facilities and capabilities at the Argonne National Laboratory-West (ANL-W) facilities located within the INEEL boundaries. ANL-W is also responding to the inquiry and will be providing an in-depth description of their unique capabilities.

- What general capabilities do you have for fuel examination? e.g., visual, profilometry, axial gamma scanning, neutron radiography, rod puncture and gas analysis, optical metallography, scanning electron microscopy on irradiated cladding/fuel, transmission electron microscopy on irradiated cladding/fuel, radiochemical gamma analysis, etc.

In conjunction with ANL-W, the INEEL has managed a number of nondestructive postirradiation examination programs on both commercial and DOE experimental reactor spent nuclear fuel and other target rods. The ANL-W submittal will describe their capabilities in detail. INEEL recently managed a PIE program that documented the visual examination and photography, neutron radiography, axial gamma scanning, contact profilometry, bow and 
length measurements, rod puncture and gas analysis, void volume determination, and internal pressure determination performed at ANL-W. Although ANL-W had the capability, the destructive portion of the PIE was performed at another DOE laboratory.

- Are you able to conduct mechanical testing on irradiated cladding? e.g., fracture toughness, creep.

Yes, in conjunction with ANL-W capabilities.

- What capabilities do you have for receiving spent fuel for examination? Are you capable of examining full-length fuel rods/assemblies? If not, what modifications would be necessary to your facility to provide this capability?

The INEEL has the TAN Hot Shop with the capabilities to transload, disassemble, and inspect spent nuclear fuel in adjacent hot cells. The INEEL has recently demonstrated the transfer of full-length commercial spent nuclear fuel rods to the ANL-W facility for detailed examination.

- Would you be able to remove individual fuel rods from a fuel assembly for examination?

Yes, this was demonstrated as part of OCRWM's dry rod consolidation program performed at the INEEL. The INEEL has equipment designs and videos of these activities. This was also recently performed as part of the NRC Dry Storage Cask program.

\section{Other Issues Associated with Demonstration Site/Fuel Characterization}

\subsection{Institutional Issues Associated with Participating in the Demonstration Program}

- What restrictions do you have on receiving and accepting commercial spent fuel? Can commercial spent fuel be shipped to your site? Can you accept responsibility for the spent fuel?

The Idaho Settlement Agreement controls receipt of commercial spent nuclear fuel at the INEEL. The INEEL can accept spent nuclear fuel for examination and evaluation; however, the INEEL cannot accept ownership and responsibility for disposal of commercial spent nuclear fuel.

- How would you dispose of the spent fuel after the demonstration project is completed (assume that it cannot be returned to the reactor operator)?

Agreements would need to be established with other DOE laboratories or commercial facilities to store the spent nuclear fuel until disposal can be accomplished at the repository. The settlement agreement requires the spent nuclear fuel to be removed from the INEEL at the end of the program.

- What would you do with the storage cask after the demonstration is completed?

Unless another program identifies a need for the storage cask, the INEEL would decontaminate and dismantle the storage cask for disposal in accordance with appropriate regulations. 
- Do you have any potential conflicts of interest if you were to participate in this demonstration project? e.g., NRC, DOE/EM, ...

None.

\subsection{Costs and Schedule Issues Associated with Participating in the Demonstration Program}

- How busy are your facilities? Are there any specific windows of opportunity or, conversely, periods when you could not accommodate the proposed work?

The INEEL is currently seeking new projects for the TAN Facility. Early planning will facilitate the INEEL ability to have TAN available when needed for this project.

- Are any of the facilities envisioned for this work scheduled for decommissioning? If so, what is the current schedule for that activity?

The ownership of TAN will be transferred from DOE-EM to DOE-NE. The future mission of the facility under DOE-NE is currently being defined.

- What are your gross estimated costs for the work you would be interested in performing? e.g., providing a demonstration site, transportation of spent fuel to/from the site, conducting pre- and post-test fuel examinations, disposing of the spent fuel, disposing of radioactive waste generated from the work, cleanup of facilities used to conduct the work, etc.

The INEEL will prepare a detailed estimate of the proposed work scope, after the detailed work scope is received. The variable in the described general work scope can have a major impact on the proposed activities.

3.3 Please provide any other information that you believe is pertinent to your site and potential participation in this project.

Please contact Mr. Tom Hill, tjh@inel.gov, for further information, or Mr. David Duncan, david.duncan@anlw.anl.gov, for ANL-W specific information. 


\section{ORNL Response to Survey Questionnaire}

National Laboratory: Oak Ridge National Laboratory (2/21/03)

Contact: Donald J. Spellman

Oak Ridge National Laboratory

PO Box 2008, MS 8057

Oak Ridge, TN 37831-8957

spellmandj@ornl.gov

(865) 574-7891

\section{Potential Demonstration Site}

- Are you interested in, or capable of, serving as the demonstration site?

Yes, ORNL is interested in serving as the demonstration site and is capable of performing the work, with certain caveats.

We are unambiguously interested in the provision of fuel PIE services. Storage of commercial spent fuel in a modified commercial dry cask (modified in a way such as to place its design outside of the licensing basis) will present some institutional issues for ORNL, and for any DOE site, that we have not had time to completely review. These institutional questions include:

- The operating and safety basis for the dry cask at the ORNL site. The demonstration unit may be required by DOE to be operated as a separate nuclear facility, alternatively, the demonstration unit might possibly be incorporated into an existing nuclear facility at the Oak Ridge Reservation;

- The necessary NEPA actions. An Environmental Assessment may be legally required by before a definitive affirmative answer can be made on site suitability/capability; and

- Spent fuel disposal path. Ownership of the spent fuel and the disposal path would need to be addressed during the establishment of the project. We believe that this issue is solvable, as ORNL and other sites do take possession of commercial spent fuel for various programs, but this issue must be dealt with explicitly during definition of the project. Options for disposal of the cask materials have also not yet been defined by the ORNL team.

- What are the general characteristics of your potential demonstration site? e.g., concrete pad, support facilities, etc.

The potential demonstration site would be the use of an existing pad or to pour a new 12' x 12' pad at the High Flux Isotope Reactor (HFIR) site. The pad and cask would be fitted with the proper tiedown devices to ensure stability. The HFIR site offers an appropriate security perimeter and nuclear operations that are compatible and similar to spent fuel storage. Formal assessment, approvals and permission to use the site for this proposed purpose would need to be engaged. 
- Do you have existing access to any intact high-burnup spent fuel rods/assemblies? If so, what is the burnup history and level, enrichment, design, or other pertinent information?

No.

- Are you able to receive full-length fuel assemblies, shipping and storage casks? Can you transload spent fuel from a shipping cask into a demonstration storage cask? What limits do you have on handling shipping casks and storage casks? What are the operational load limits of your cranes that could be used for handling transportation and storage casks?

Yes, we are able to handle full-length assemblies in one of our large hot cells in a building near the HFIR reactor but not at the Irradiated Fuels Examination Laboratory (IFEL), where the actual PIE of the rods would be done.

Yes, we can transload bundles or rods from a shipping cask to a storage cask. The use of multi-rod packages as discussed below is the preferred method due to (1) the fact that no fuel assemblies have been irradiated to the target burnups (only rods), (2) the complications of handling an irradiated bundle in the transfer process and (3) the desire to minimize unused radioactive wastes at ORNL.

The particular site will need to be formally evaluated and approved by DOE for an irradiated fuel storage cask. A cask SAR will need to be prepared to establish a safety basis compliant to DOE Orders.

ORNL has available a number of mobile cranes on the X-10 site. Capacities are: $75 \mathrm{~T}, 50 \mathrm{~T}, 30 \mathrm{~T}$, $15 \mathrm{~T}$, plus a number of smaller (roustabout) cranes for use within buildings. We have been using the $50 \mathrm{~T}$ crane recently for drop tests on shipping casks at the ORNL National Transportation Research Center.

- Can you arrange for transportation of selected spent fuel from the reactor to your site if needed? What is your previous experience in arranging for transportation of spent fuel?

Yes, ORNL has had preliminary discussions with a commercial spent fuel shipping company and transportation of spent fuel to the site can be arranged. As part of research activities on irradiated fuels, there is adequate experience in transporting sections of spent nuclear fuel rods at ORNL. A component of onsite reactor operations involves the shipment of DOE spent fuels, such as spent HFIR cores.

- Can you collect, and then analyze, gases from the storage cask? Gas analysis will require radiochemical gamma analysis in addition to mass spectrometry.

Yes. We have fully functional capabilities for gas analysis that are used on a routine basis. Special instrumentation for collection of gases would have to be built for the cask. Additionally, the cask head would need to be modified to accept the instrumentation and allow removal of rod bundles at 5 years and 10 years.

\section{Fuel Characterization Site}

- Are you interested in providing fuel examination services? 
Yes. This proposed task fits well with our MOX fuel handling and examination work that has been going on at ORNL since 1998 for the Fissile Materials Disposition Program. For the FMDP program, ORNL coordinated the irradiation of 11 short MOX fuel pins at ATR in Idaho, and shipped the pins to ORNL (in four shipments corresponding to four different levels of fuel burnup), and conducted post irradiation examination of those pins for all elements of interest to the NRC for licensing that fuel in U.S. commercial reactors. Reports of these examinations can be provided.

- What general capabilities do you have for fuel examination? e.g., visual, profilometry, axial gamma scanning, neutron radiography, rod puncture and gas analysis, optical metallography, scanning electron microscopy on irradiated cladding/fuel, transmission electron microscopy on irradiated cladding/fuel, radiochemical gamma analysis, etc.

Capabilities currently in use at ORNL are visual examination, metrology, gamma scan, rod puncture and fission gas measurement, ceramography, SEM/EPMA, immersion density (replaced by gas compression technique), optical metallography (cross sections for evidence of chemical reactions), quantitative metallography (hydrogen content and hydride characteristics), scanning electron microscope, and radiochemistry (source term, fission products, chemical distribution).

Two of the listed capabilities exist but are currently configured only for short fuel rods, namely profilometry and axial gamma scan diagnostics. Some relatively minor modifications to our equipment can be made so as to adapt these diagnostic systems for full-length rods. These modifications have been evaluated and are planned to be funded as part of DOE/NNSA Fissile Materials Disposition Program.

Neutron radiography, eddy current, and transmission electron microscopy capabilities are not in place for irradiated fuel specimens.

- Are you able to conduct mechanical testing on irradiated cladding? e.g., fracture toughness, creep.

Yes, creep measurements and fracture toughness can be accomplished in either of two facilities (a beta-gamma facility and an alpha facility) depending on the level of decontamination that can be accomplished of the residual fuel adhering to the cladding.

ORNL has also developed a new method of cladding stress/strain measurements that is unique and used in our fuels PIE facility. Our process tests the pure stress/strain of the cladding without introducing any interfering bending moments. The NRC is familiar with our method, and it will be used on irradiated MOX fuel in FY 2003.

- What capabilities do you have for receiving spent fuel for examination? Are you capable of examining full-length fuel rods/assemblies? If not, what modifications would be necessary to your facility to provide this capability?

Currently, ORNL's fuel PIE facility, Building 3525 IFEL, is capable of handling only short fuel rods, up to $5 \mathrm{ft}$ in length. Modifications are planned, as discussed below, to permit receipt and evaluation of full-length rods. Building 3525 is not capable of accepting full-length fuel assemblies. 
In principle, full-length bundles can be handled in the Radiochemical Engineering Development Center (REDC), a large hot cell facility located at the HFIR reactor site. In practice, though, the receipt and handling of full fuel bundles at the ORNL site is not proposed because it would add considerable expense to the project and increase the waste issues to be accommodated due to unused irradiated pins and irradiated assembly components. Instead, ORNL proposes that packets of high-burnup fuel rods be pulled from spent fuel assemblies at the reactor pools where they are stored and shipped to ORNL. Upon receipt at ORNL, the fuel rods would be transferred directly from the shipping cask to the storage cask and placed into a spacer array so that only the quantity of spent fuel needed for the PIEs is actually transferred to the DOE site. Temperature requirements for the storage experiment could be met as needed by use of internal heaters in the storage cask. Removal of individual rods for fuel PIE from the storage and transfer to the shipping cask would be accomplished by use of special fixturing.

The advantage of this arrangement is that it minimizes potential DOE liabilities and costs by limiting receipt of spent fuel to only those rods that are planned to under destructive examination.

Modification to IFEL to accept full-length fuel rods. Two upgrades are needed to complete the ORNL IFEL hot cell preparations for moving full-length rods from a spent fuel cask into the hot cells. The internal building crane at the loading area of IFEL needs to be upgraded. The crane replacement/upgrade will be completed in the next two years as part of planned upgrades. The other is to design and build a mating flange from the LWT shipping cask to the hot cell. This project is also already planned by ORNL for completion by FY 2007 under funding from the Fissile Materials Disposition Program. If earlier implementation of this mating flange were needed for this task, than the cost of the upgrade would need to be borne by this project.

- Would you be able to remove individual fuel rods from a fuel assembly for examination?

Yes, we have this capability in principle, but we are not proposing to do so. The removal of fuel rods would best be accomplished at the commercial reactor site. The plan would be to design a transfer cask that would fit over the dry storage cask head. The head would have a designed opening in it to allow a number of rods from the interior of the dry storage cask. If rods only were stored in the dry storage cask, it would be relatively simple to design the system so that a packet of rods can be readily removed. This method would allow the transfer of the rods to a transfer cask, placement of the rods from the transfer cask into an LWT shipping container and movement directly into the IFEL hot cells. The advantage of this method, as mentioned earlier is that it minimizes DOE waste disposal quantities and costs for the experiment by avoiding the receipt of full bundles of spent fuel.

\section{Other Issues Associated with Demonstration Site/Fuel Characterization}

\subsection{Institutional Issues Associated with Participating in the Demonstration Program}

- What restrictions do you have on receiving and accepting commercial spent fuel? Can commercial spent fuel be shipped to your site? Can you accept responsibility for the spent fuel? 
Any commercial spent fuel accepted at ORNL would have to be approved for handling within the SAR of the facility proposed. ORNL has previously handled the spent fuel shipping casks that are proposed for this project. Responsibility for the spent fuel can be accepted as long as a waste products strategy has been developed and approved by DOE.

- How would you dispose of the spent fuel after the demonstration project is completed (assume that it cannot be returned to the reactor operator)?

As part of a past DOE consolidation effort for spent fuel, ORNL has recently repackaged all legacy spent fuel into cans for temporary storage and eventual shipment to INEEL. A similar arrangement would have to be developed and approved by DOE. No approved path forward is in place at this time.

- What would you do with the storage cask after the demonstration is completed?

We have not yet evaluated this issue. The specific strategy would certainly depend upon the level of radioactivity, if any, associated with the cask. In general, we would probably propose to use the cask for subsequent experiments, or dispose of it in a manner similar to that planned by commercial users of spent fuel casks.

- Do you have any potential conflicts of interest if you were to participate in this demonstration project? e.g., NRC, DOE/EM, ...

ORNL knows of no current or former activities that would constitute the appearance or actual COI for this work.

\subsection{Cost and Schedule Issues Associated with Participating in the Demonstration Program}

- How busy are your facilities? Are there any specific windows of opportunity or, conversely, periods when you could not accommodate the proposed work?

Currently, the facilities are under-utilized and new work is being actively sought. We have performed a preliminary analysis of work schedules and envision no conflicts with other planned projects.

- Are any of the facilities envisioned for this work scheduled for decommissioning? If so, what is the current schedule for that activity?

No.

- What are your gross estimated costs for the work you would be interested in performing? e.g., providing a demonstration site, transportation of spent fuel to/from the site, conducting pre- and post-test fuel examinations, disposing of the spent fuel, disposing of radioactive waste generated from the work, clean-up of facilities used to conduct the work, etc.

It is very difficult to develop a cost estimate of this project because there is not enough specific definition of the work scope (the nature of PIE tests, etc.) and certain operational and waste disposal costs depend upon decision processes that have not yet occurred. Attached is a list of assumptions and a very rough estimate of cost. Discussion with a commercial fuel vendor about 
National laboratory responses to pnnl survey questionnaire

transportation and design and costs of the proposed transfer cask fixturing have been used as the basis for parts of this estimate, but all aspects of this estimate should be treated as highly preliminary.

\subsection{Please provide any other information that you believe is pertinent to your site and potential participation in this project.}

ORNL is committed to expand its role and activity in nuclear energy technology, as part of the UTBattelle Strategic Plan for the Laboratory. ORNL has an existing institutional infrastructure for nuclear operations, radiological safety, etc. that is appropriate for this project because its operation of the HFIR and the handling of spent fuel and irradiated actinide targets at REDC and the IFEL.

The ORNL strategy for this project would entail two key areas of cooperation (outside of the DOE complex). First an external arrangement would need to be made with the utility that has ownership of the fuel. We believe that the proposed strategy involves operations and arrangements that are consistent with current operations and other past arrangements. An additional partnership with a commercial packaging/transportation company would be desirable, as it would benefit overall planning at the earliest stages and potentially lower the cost to the project sponsor.

Our recommended plan would be to first remove several sets (up to 10 rods each) from selected bundles at the reactor site and load each set into a special container manufactured for this project (a long tube that holds from 4 to 10 rods). The rods would be selected based on their burnup history. Respective sets could contain rods that had been burned to $45,55,65$, and $75 \mathrm{GWd} / \mathrm{MT}$. Individual bundles have not been burned above about $60 \mathrm{GWd} / \mathrm{MT}$ to date and the shipping casks for bundles are only certified for $45 \mathrm{GWd} / \mathrm{MT}$ average bundle burnup. Shipping casks are, however, certified for shipment of up to 25 rods that have been burned to $80 \mathrm{GWd} / \mathrm{MT}$.

ORNL's proposal would be set up to handle a number of rods that would be selected and loaded at the utility site (e.g., at the reactor pool where fuel rod disassembly is readily accomplished using commercial robotic systems.) We would propose to select four sets of 5 to 10 rods that have been burned to $45,55,65$, and $75 \mathrm{GWd} / \mathrm{MT}$ and put them in individual canisters that are 4 " in diameter. [It may be desirable to load one additional set of the rods at the reactor pool into a spent fuel shipping cask for shipment directly to IFEL for initial PIE]. (The advantage of this plan is that there are no bundles in the utility inventory that have been burned to an average burnup of 65 or $75 \mathrm{GWd}$ but there are individual rods that have been burned to this level.)

The four 4-inch tubes would be inserted into a 13-inch container that would fit inside an NAC LWT and/or NLI cask. The LWT, which is currently licensed for 80GWd for rods and only $45 \mathrm{GWd}$ for bundles, would be used to transport the four canisters in the 13-inch container to ORNL. The NLI cask would be modified to allow the necessary instrumentation to be inserted into the head (actually, there is an inner and an outer head to accommodate a shutter mechanism for fuel transfers). At ORNL, a transfer cask would be fitted to the LWT to extract the 13-inch container and move it into the NLI cask that is sitting on a concrete pad at HFIR. Then the LWT would be returned to service and the NLI cask would be left at the HFIR site for up to 10 years. At the fiveyear point, the transfer cask would be again attached to the NLI and the heads opened to remove one of the 4-inch canisters to move it to an LWT cask for transport to 3525 for PIE. ORNL would 
validate calculations to ensure that this storage method would be prototypic of dry storage of 31 bundles at the utility. It is also possible to install heaters or other instrumentation in the ORNL storage cask if necessary to more closely simulate utility storage conditions.

The biggest advantage of this method is that the high cost of trying to dispose of a number of complete bundles would be avoided.

\section{Assumptions made to develop rough estimate of cost for dry spent fuel storage experiment at ORNL}

1. Four packets of five rods with similar burnups would be assembled and placed in four canisters at the reactor site. Special rod canisters, 4 inches in diameter would be designed and built to carry these rod packets. (Grid spacers can be designed to simulate actual rod separations as experienced in a full fuel bundle.)

2. One extra rod packet of two rods would also be assembled at the reactor site pool and shipped directly by an LWT spent fuel cask to the ORNL hot cell building for initial post-irradiation examination.

3. A 13-inch carry-case container would be designed and built to carry the four-rod packets inside an LWT cask to the ORNL site storage facility near the HFIR reactor.

4. At the HFIR site, a transfer cask would be used to transfer the four packets in the 13-inch carrycase from the LWT shipping cask to a modified NLI cask that will be used for the dry storage experiment.

5. This NLI storage cask will have replacement heads (2) redesigned to allow bolting of the head vise the normal welding method. The new head will have instrumentation holes to accommodate instrumentation and cask atmosphere control devices such as heater ports and helium charging connection to ensure that full bundle conditions are duplicated in the dry storage cask during the project.

6. A new $12 \times 12$-ft concrete pad will be constructed at the HFIR site with appropriate hold-down connections to meet seismic requirements.

7. A HFIR site SAR revision will be required to allow this NLI cask storage experiment and an Environmental Assessment will be required.

8. One packet of 5 rods will be pulled from the NLI storage cask at 5 years, and one packet will be pulled at 10 years for nondestructive and destructive PIE.

9. Approximately $\$ 400 \mathrm{~K}$ will be needed to design and build a special mating flange for the LWT cask to the ORNL hot cell such that individual rods can be removed from the five rod packets and meet ALARA requirements.

10. The ORNL IFEL SAR will not need revision. 
11. All high-level waste from the post irradiation examinations and remaining irradiated fuel rods will be packaged and stored at ORNL site for five years after project completion for eventual disposition in am manner to be determined.

12. The inner containers and dry storage cask will be decontaminated and stored at ORNL site for five years after project completion for eventual disposal as LLW.

The costs in the table below are very rough estimates of the different cost categories that are proposed for this task based on the assumptions made above.

\begin{tabular}{|l|c|}
\hline \multicolumn{1}{|c|}{ Task Category } & $\begin{array}{c}\text { Cost Estimate } \\
(\mathbf{( K )}\end{array}$ \\
\hline Equipment & 1800 \\
\hline Transportation & 1200 \\
\hline Fuel Handling & 1500 \\
\hline Post-Irradiation Examinations & 5300 \\
\hline Waste Handling & 3300 \\
\hline Licensing/NEPA/Permits & 1600 \\
\hline Labor & 2300 \\
\hline Total & 17000 \\
\hline
\end{tabular}




\title{
PNNL Response to Survey Questionnaire
}

\author{
National Laboratory: Pacific Northwest National Laboratory
}

Contact: John Abrefah

email: john.abrefah@pnl.gov

(509) 373-0927

\section{Potential Demonstration Site}

- Are you interested in, or capable of, serving as the demonstration site?

Yes, a team comprising staff at the Radiological Processing Laboratory (RPL) and Energy Northwest would like to be given the opportunity to perform the demonstration work.

- What are the general characteristics of your potential demonstration site? e.g., concrete pad, support facilities, etc.

The RPL is a Category II nuclear facility with hot cells and the research equipment that can be used to perform the PIE work including extensive optical capabilities. The concrete pads that are available at Energy Northwest, and the 200-Area of the Hanford site could easily be used to store and monitor the demonstration cask.

- Do you have existing access to any intact high-burnup spent fuel rods/assemblies? If so, what is the burnup history and level, enrichment, design, or other pertinent information?

Depending on the time that we are asked to start the fuel loading, Energy Northwest may have in their spent fuel inventory, the fuel with burnup characteristics of interest. But we propose to include other fuel types in the demonstration. Currently, there is not a specific injunction by either the State of Washington or DOE that will stop shipment of fuel from other utilities to the site for the demonstration project. However, we have to obtain the approval by DOE-RL to bring spent fuel to the site. In addition, the license of Energy Northwest may have to be granted a variance and/or modification by NRC for the receipt of spent fuel from other utilities. The logistics of that process are yet to be worked out.

- Are you able to receive full-length fuel assemblies, shipping and storage casks? Can you transload spent fuel from a shipping cask into a demonstration storage cask? What limits do you have on handling shipping casks and storage casks? What are the operational load limits of your cranes that could be used for handling transportation and storage casks?

The Energy Northwest spent fuel pool could be used to receive and load full-length rods if granted the variance by NRC. For the demonstration option involving a full cask load, there is no facility on site to perform the dry transfer of fuel assembly from the storage cask to a shipping cask. We propose the need to build a mobile system to accomplish such transfer since that system could also be made available to other utilities that may need that capability to ship their stored spent fuel to the proposed repository. 
- Can you arrange for transportation of selected spent fuel from the reactor to your site if needed? What is your previous experience in arranging for transportation of spent fuel?

PNNL has expertise that is currently involved in the shipment of spent fuel and TRU waste and they are well aware of the processes and regulations. Their knowledge and expertise will explore to lead any effort to ship spent fuel to the site for the project. Additionally, the team at Energy Northwest will handle the coordinating for the shipment of spent fuel to their site.

- Can you collect, and then analyze, gases from the storage cask? Gas analysis will require radiochemical gamma analysis in addition to mass spectrometry.

The Mass Spectrometry Laboratory at RPL is well equipped to analyze all gas species of interest and the radiochemical counting laboratory will perform the gamma analysis for fission gas detection and quantification.

\section{Fuel Characterization Site}

- Are you interested in providing fuel examination services?

Yes. The RPL is one of the premier labs in this country that is well equipped to provide fuel examination services to this demonstration project. It is a Cat II facility that is actively involved in diversified radiological research in support of other DOE missions including the clean up of the Hanford site.

- What general capabilities do you have for fuel examination? e.g., visual, profilometry, axial gamma scanning, neutron radiography, rod puncture and gas analysis, optical metallography, scanning electron microscopy on irradiated cladding/fuel, transmission electron microscopy on irradiated cladding/fuel, radiochemical gamma analysis, etc.

The hot cells in RPL are not currently configured to handle a full-length LWR rod examination but it can be modified with funding to provide all the fuel examination activities including:

Visual inspection using high-resolution digital cameras

Profilometry

Axial gamma scans

Neutron radiography.

For the other set of PIE activities including optical examination using high-resolution optical microscopy, scanning electron microscopy and transmission electron microscopy on cladding materials, the equipment are currently available at RPL and other PNNL facilities including Buildings 326 and 323 in the 300-Area.

- Are you able to conduct mechanical testing on irradiated cladding? e.g., fracture toughness, creep

PNNL has a system set up in a mini-cell in the 323 Bldg that is dedicated to perform creep and tensile testing of spent fuel cladding. That system may be used to support this demonstration project or it can be duplicated in the RPL hot cells to perform the creep and toughness tests. 
- What capabilities do you have for receiving spent fuel for examination? Are you capable of examining full-length fuel rods/assemblies? If not, what modifications would be necessary to your facility to provide this capability?

The hot cells in RPL are not large enough to handle a full-length LWR fuel rod examination but there is a plan in place to modify one of the three hot cells (i.e., A-cell) in the High Level Radiological Facility (HLRF) to be able to handle and examine a full-length rod and/or an assembly. The plan includes an attachment of an air-lock system to A-cell and installment of PIE equipment. The schematic of the plan is shown in the attached write up.

- Would you be able to remove individual fuel rods from a fuel assembly for examination?

The modification plan will include the capability to extract a full-length rod from an assembly for examination.

\section{Other Issues Associated with Demonstration Site/Fuel Characterization}

\subsection{Institutional Issues Associated with Participating in the Demonstration Program}

- What restrictions do you have on receiving and accepting commercial spent fuel? Can commercial spent fuel be shipped to your site? Can you accept responsibility for the spent fuel?

There is no restriction that should stop shipment of spent fuel to the Hanford Site but any spent fuel movement to the site will have to go through a formal DOE approval.

- How would you dispose of the spent fuel after the demonstration project is completed (assume that it cannot be returned to the reactor operator)?

The approved project under the guidance of U.S. Department of Energy, Richland Operations will assume ownership of the spent fuel. The fuel disposal pathway that will have to be approved by DOE-RL will be to add the demonstration cask storage system with all its spent fuel to the inventory of spent fuel at the Hanford site. This will then create the same pathway for final disposition, which currently is the proposed geologic repository at Yucca Mountain (YM). If approved by DOE, the demonstration cask and its fuel content can be stored together with the other Hanford spent fuel at the concrete pad in the 200-Area awaiting the opening of YM repository.

- What would you do with the storage cask after the demonstration is completed?

The storage cask can be buried as low-level waste at the Hanford site if it is not used to ship the fuel to the YM repository.

- Do you have any potential conflicts of interest if you were to participate in this demonstration project? e.g., NRC, DOE/EM, ...

There is no known conflict of interest for our involvement in the demonstration project. 


\subsection{Cost and Schedule Issues Associated with Participating in the Demonstration Program}

- How busy are your facilities? Are there any specific windows of opportunity or, conversely, periods when you could not accommodate the proposed work?

The RPL is available to support the demonstration work that will be based on an agreed schedule to meet the major milestones required by the project. The only schedule limitation might come from the Energy Northwest. We may have to schedule fuel receipt and loading activities such that it had minimum impact to the operation of their plant.

- Are any of the facilities envisioned for this work scheduled for decommissioning? If so, what is the current schedule for that activity?

Due to RPL importance in supporting the Hanford site clean up mission, there is a tentative agreement with DOE-RL to keep this facility open and operational at least until the year 2028. That should give the project adequate time to complete the entire scheduled testing if the project starts on the schedule time of 2005/2006.

- What are your gross estimated costs for the work you would be interested in performing? e.g., providing a demonstration site, transportation of spent fuel to/from the site, conducting pre- and post-test fuel examinations, disposing of the spent fuel, disposing of radioactive waste generated from the work, clean-up of facilities used to conduct the work, etc.

The rough estimate for the full cask demonstration option work including the mobile dry transfer facility, fuel consolidation and modification to A-cell in RPL to receive a fuel assembly is between \$21.8M to $\$ 26.9 \mathrm{M}$.

For the second option that involves only 2 fuel assemblies and modification to examine full-length rood at the HLRF of RPL, the total cost in the range of \$15.3M.

3.3 Please provide any other information that you believe is pertinent to your site and potential participation in this project. (See the attached proposal). 



\section{SRS Response to Survey Questionnaire}

National Laboratory: Savannah River Technology Center

Contact: Mark E. Dupont

mark.dupont@srs.gov

(803) 725-0954

\section{Potential Demonstration Site}

- Are you interested in, or capable of, serving as the demonstration site?

Yes.

- What are the general characteristics of your potential demonstration site? e.g., concrete pad, support facilities, etc.

Savannah River Site (SRS) is one of the 2 DOE sites for the receipt and storage of foreign and domestic research reactor spent fuels. It is also the storage site for the spent fuel from 5 DOE production reactors. SRS has spent fuel receipt, fuel handling, fuel assembly and storage facilities for the growing inventory of spent fuels. These facilities include: CSX rail access, 120 ton building and 100 ton portable cranes, cask decontamination facilities, concrete storage pads, etc. Sufficient real estate exists on the 300 square mile site to construct any additional needed pads or facilities, if desired.

- Do you have existing access to any intact high-burnup spent fuel rods/assemblies? If so, what is the burnup history and level, enrichment, design, or other pertinent information?

SRS wet and dry storage facilities currently contain spent fuel assemblies with a range of irradiation histories. However, most of these assemblies are from research or material production reactors. SRS does store limited amount of Zircaloy-clad fuels. Furthermore, there are almost $800 \mathrm{SNF}$ assemblies with burnups $>45 \mathrm{GWD} / \mathrm{MTU}$ in storage at utility reactors in South Carolina (SC), or immediately adjacent to the SRS at Vogtle in Georgia. The only known assembly with burnup $>60 \mathrm{GWD} / \mathrm{MTU}$ is also in storage at an SC utility (Summer).

- Are you able to receive full-length fuel assemblies, shipping and storage casks? Can you transload spent fuel from a shipping cask into a demonstration storage cask? What limits do you have on handling shipping casks and storage casks? What are the operational load limits of your cranes that could be used for handling transportation and storage casks?

SRS has one cask-receiving basin, which could receive a shipping cask containing full-length commercial assemblies.

SRS has transloaded research reactor spent fuel, dry, utilizing fuel transfer casks. Similar techniques system and systems may be used for transfer of commercial SNF. 
SRS has 120 ton building and 100-ton portable cranes which could be used to unload shipping casks from trucks or railcars and transload SNF from shipping to storage casks. Building access is limited to a 20 - $\mathrm{ft}$ tall X $18 \mathrm{ft}$ wide door at the rail access portal. Building crane clearance is $>30 \mathrm{ft}$ vertically.

- Can you arrange for transportation of selected spent fuel from the reactor to your site if needed? What is your previous experience in arranging for transportation of spent fuel?

SRS has extensive experience with all aspects of movement of SNF and casks, both domestically and internationally, as part of a program for the receipt of highly enriched foreign research reactor fuel.

- Can you collect, and then analyze, gases from the storage cask? Gas analysis will require radiochemical gamma analysis in addition to mass spectrometry.

SRS has extensive experience with collection and analysis of radioactive gases, including mass spectrometry, gamma spectroscopy, gas chromatography, etc. In addition, SRS has experience with the design of in-situ gas analysis systems, which may be appropriate for this program. It has adapted state-of-art gas collection systems as part of its ongoing demonstration of the dry storage system for research reactor SNF.

\section{Fuel Characterization Site}

- Are you interested in providing fuel examination services?

SRS has facilities for comprehensive nondestructive and destructive examination of spent fuel sections. SRS facilities include appropriate shielded cells with manipulators (high-level caves) for metallurgical characterization.

- What general capabilities do you have for fuel examination?

General capabilities include a range of nondestructive techniques including visual, profilometry, axial gamma scanning, rod puncture and gas analysis, and metallurgical characterization tools.

- Are you able to conduct mechanical testing on irradiated cladding? e.g., fracture toughness, creep

Current capabilities only include mechanical testing (creep, fatigue, etc.) of nuclear materials, however, the facility can be adapted to test irradiated cladding.

- What capabilities do you have for receiving spent fuel for examination? Are you capable of examining full-length fuel rods/assemblies? If not, what modifications would be necessary to your facility to provide this capability?

SRS capabilities include receipt/handling capabilities. Current capabilities cannot accommodate full-length fuel assemblies, however, such capabilities are being contemplated to accommodate needs of new missions, e.g., irradiated tritium producing burnable absorber rods (TPBAR) from commercial reactors and MOX fuel fabrication. 
- Would you be able to remove individual fuel rods from a fuel assembly for examination?

SRS has extensive capabilities and experience in remote tooling, handling and can readily develop fixtures and tools to remove fuel rods for examination.

\section{Other Issues Associated with Demonstration Site/Fuel Characterization}

\subsection{Institutional Issues Associated with Participating in the Demonstration Program}

- What restrictions do you have on receiving and accepting commercial spent fuel? Can commercial spent fuel be shipped to your site? Can you accept responsibility for the spent fuel?

SRS does not have any known radiological restrictions, which would prevent receipt of commercial spent fuel. Formal requests will be made to the authorizing agencies upon initiation of a program. Political liabilities, if any, and legal obligations related to the receipt of commercial spent fuel would have to be identified and addressed.

- How would you dispose of the spent fuel after the demonstration project is completed (assume that it cannot be returned to the reactor operator)?

All DOE-owned spent fuels currently at SRS will eventually be transferred to the proposed geologic repository. The disposition of the spent fuel from this program would have to be negotiated as part of the program.

- What would you do with the storage cask after the demonstration is completed?

SRS has sufficient facilities to retain a storage cask. Alternatively, the cask could be made available for other use.

- Do you have any potential conflicts of interest if you were to participate in this demonstration project? e.g., NRC, DOE/EM, ...

None known.

\subsection{Cost and Schedule Issues Associated with Participating in the Demonstration Program}

- How busy are your facilities? Are there any specific windows of opportunity or, conversely, periods when you could not accommodate the proposed work?

SRS facilities will be involved with receipt of foreign research reactor spent fuels through 2009 and with receipt of domestic research reactor spent fuels for an indefinite time. The receipt of a commercial spent fuel cask could be accommodated without significant interruption of these schedules.

- Are any of the facilities envisioned for this work scheduled for decommissioning? If so, what is the current schedule for that activity? 
One of the three SRS basins is scheduled for deinventory and closure by 2006. All other SRS facilities will remain available for use for the foreseeable future.

- What are your gross estimated costs for the work you would be interested in performing? e.g., providing a demonstration site, transportation of spent fuel to/from the site, conducting pre- and post-test fuel examinations, disposing of the spent fuel, disposing of radioactive waste generated from the work, clean-up of facilities used to conduct the work, etc.

It would not be prudent to provide gross cost estimates without knowing a detailed scope. However, the SRS and SRTC labor-costing rate is the lowest among the DOE labs.

3.3 Please provide any other information that you believe is pertinent to your site and potential participation in this project.

See attached brochure. 